Andrews University

Digital Commons @ Andrews University

\title{
A Strategy for Church Planting in Northern Nigeria Beginning in Zangon-Kataf
}

Francis F. Daria

Andrews University

Follow this and additional works at: https://digitalcommons.andrews.edu/dmin

Part of the Practical Theology Commons

\section{Recommended Citation}

Daria, Francis F., "A Strategy for Church Planting in Northern Nigeria Beginning in Zangon-Kataf" (2011).

Professional Dissertations DMin. 527.

https://dx.doi.org/10.32597/dmin/527

https://digitalcommons.andrews.edu/dmin/527

This Project Report is brought to you for free and open access by the Graduate Research at Digital Commons @ Andrews University. It has been accepted for inclusion in Professional Dissertations DMin by an authorized administrator of Digital Commons @ Andrews University. For more information, please contact repository@andrews.edu. 


\begin{abstract}
A STRATEGY FOR CHURCH PLANTING IN NORTHERN NIGERIA

BEGINNING IN ZANGON-KATAF
\end{abstract}

by

Francis F. Daria

Adviser: Bruce Campbell Moyer 


\author{
ABSTRACT OF GRADUATE STUDENT RESEARCH \\ Project Dissertation \\ Andrews University \\ Seventh-day Adventist Theological Seminary
}

\title{
Title: A STRATEGY FOR CHURCH PLANTING IN NORTHERN NIGERIA BEGINNING IN ZANGON-KATAF
}

Name of Researcher: Francis F. Daria

Name and degree of faculty adviser: Bruce Campbell Moyer, STD

Date completed: May 2011

Problem

The first Adventist missionaries came to Northern Nigeria in 1930. Their intent to establish medical and evangelistic work in Southern Kaduna was restricted by three opposing factions. These were Sudan Interior Mission (SIM), Islam and African Traditional Religion (ATR). They frustrated the indigenous people from understanding the concept of the missionaries. Eighty years later there is still no Adventist presence in this area, which is part of the 10/40 Window that encompasses all of Northern Nigeria. During these 80 years no Adventist Church has been established in this region. There is, therefore, a need to develop a church planting strategy for the Seventh-day Adventist Church to reach Muslims in Northern Nigeria. 


\section{Method}

Current literature dealing with church planting in general and among the Muslims in particular has been reviewed through library research. These include books, journals, and articles on church planting strategies, critical contextualization, and Muslim evangelism. Seminars, workshop, and training programs will be conducted for the pastors, laity, and global mission pioneers. Demographic data of Zangon-Kataf district will be collected and analyzed. A profile of people groups in this region will be developed. A strategy for church planting will be developed for the Seventh-day Adventist Church in Northern Nigeria.

\section{Expectation}

This project dissertation is designed to create a church planting strategy to be used by the Seventh-day Adventist Church leaders working among Muslims in Northern Nigeria. The achievement will begin to fulfill the mission of the pioneering missionaries, who viewed the area as the best opening for church-planting and the Seventh-day Adventist global mission. It will also increase my knowledge of mission and deepen the quality of my spiritual wellbeing. The research will provide contextualized church planting concepts that may potentially be beneficial to others and serve as a source of motivation for mission. The success of this project will contribute to the fulfillment of the gospel commission in Matthew 28:19-20. 
Andrews University

Seventh-day Adventist Theological Seminary

\title{
A STRATEGY FOR CHURCH PLANTING IN NORTHERN NIGERIA BEGINNING IN ZANGON-KATAF
}

\author{
A Project Dissertation \\ Presented in Partial Fulfillment \\ of the Requirements for the Degree \\ Doctor of Ministry
}

by

Francis F. Daria

May 2011 
(C) Copyright by Francis F. Daria 2011

All Rights Reserved 


\title{
A STRATEGY FOR CHURCH PLANTING IN NORTHERN NIGERIA BEGINNING IN ZANGON-KATAF
}

\author{
A project dissertation \\ presented in partial fulfillment \\ of the requirements for the degree \\ Doctor of Ministry
}

\section{by}

Francis F. Daria

APPROVAL BY THE COMMITTEE:

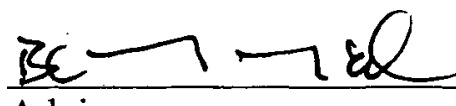

Adviser,

Bruce Campbell Moyer
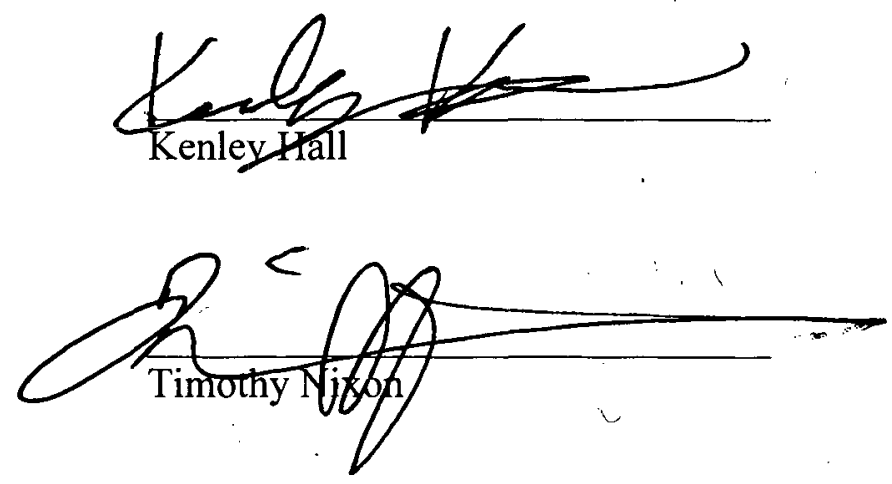

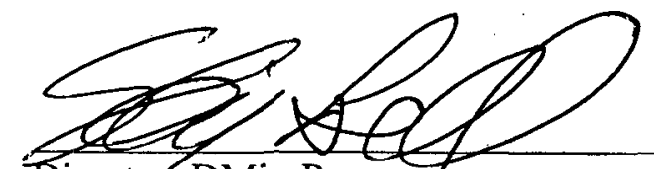

Director, DMin Progran

Skip Bell

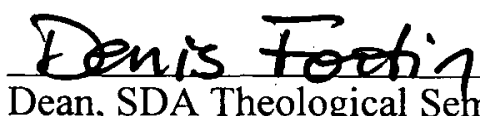

Dean, SDA Theological Seminary

Denis Fortin

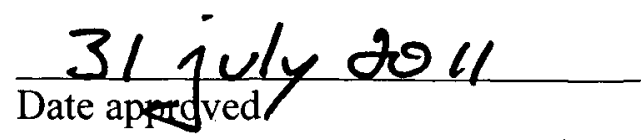


To Tani

Wife and Companion in Ministry 


\section{TABLE OF CONTENTS}

LIST OF FIGURES $\ldots \ldots \ldots \ldots \ldots \ldots \ldots \ldots \ldots \ldots$ viii

LIST OF TABLES $\ldots \ldots \ldots \ldots \ldots \ldots \ldots \ldots \ldots \ldots \ldots$ viii

LIST OF ABBREVIATIONS $\ldots \ldots \ldots \ldots \ldots \ldots \ldots \ldots \ldots \ldots \ldots$

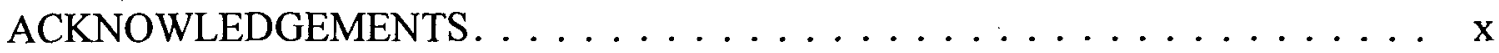

Chapter

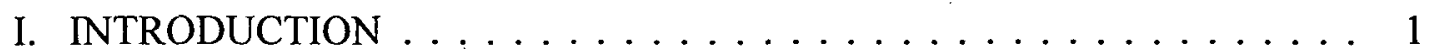

Personal History $\ldots \ldots \ldots \ldots \ldots \ldots \ldots \ldots \ldots$

Statement of the Problem . . . . . . . . . . . . . . 2

Purpose of the Project . . . . . . . . . . . . . . 3

Justification for the Project . . . . . . . . . . . 4

Expectation from the Project . . . . . . . . . . . . 4

Limitation of the Project. . . . . . . . . . . . . 5

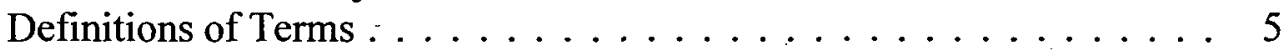

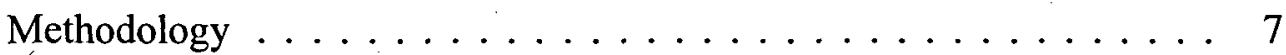

Organization of the Study . . . . . . . . . . . . . 7

II. THEOLOGICAL FOUNDATION FOR CHURCH PLANTING . . . . . . . 9

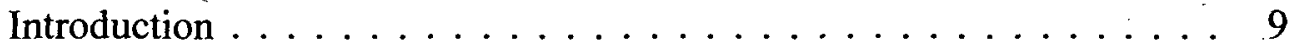

Biblical Principles for Church Planting . . . . . . . . . . 10

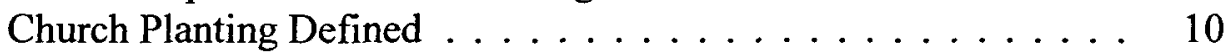

The Mission of Christ on Earth . . . . . . . . . . 12

John Writes about Christ's Mission . . . . . . . . . . . . 12

.Christ's Mission in the New Testament. . . . . . . . . . . . . . 13

Christ Came to Establish His Church . . . . . . . . . . . . . 13

The Gospel Commission . . . . . . . . . . . . . . . 14

Reasons for Planting New Churches . . . . . . . . . . . . . . 15

The Missionary Strategy of the Early Church. . . . . . . . . . . 17

The Ministry of the Holy Spirit. . . . . . . . . . . . . . 18

Earnest Prayer . . . . . . . . . . . . . . . . . 19

Relentless Evangelism. . . . . . . . . . . . . . 21

Public Evangelism. . . . . . . . . . . . . . . . . 21 
Relational Evangelism . . . . . . . . . . . . 22

Culturally Relevant Evangelism . . . . . . . . . . . . 23

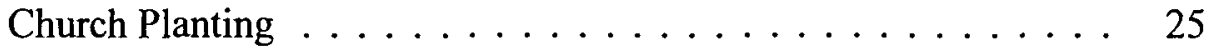

Holistic Small Groups . . . . . . . . . . . . . . . . 26

Spiritual Leadership . . . . . . . . . . . . . . . . 28

Ellen White on Church Planting . . . . . . . . . . . . . 32

Making the Strategy Culturally Appropriate to the Target Audiences. . 34

Summary. . . . . . . . . . . . . . . . . . 37

III. LITERATURE REVIEW ON CHURCH PLANTING STRATEGIES . . . 39

Introduction . . . . . . . . . . . . . . . . 39

Growth of the Christian Church on the Continent of Africa . . . . 40

The Advent Movement and Church Planting. . . . . . . . . 41

Why Plant Churches? . . . . . . . . . . . . . . . . . . . 44

Strategies for Church Planting . . . . . . . . . . . . . 46

Strategy One-Educate for Awareness . . . . . . . . . . . . 47

Strategy Two-Communicate the Progress of the New

Congregation. . . . . . . . . . . . . . . . . 48

Strategy Three-New Congregations in the Cities . . . . . . . 48

Strategy Four-Large Congregations Become Parents . . . . . . . 50

Strategy Five-Planting by Transplanting. . . . . . . . . . . 51

Universal Element in Church Planting. . . . . . . . . . . . . . . . . 53

Obstacles to Church Planting . . . . . . . . . . . . . . . . . . 54

Imposing Extra-biblical Requirements for Being a Church . . . . 55

Loss of a Valued Cultural Identity . . . . . . . . . . . . . . 55

Overcoming Bad Examples of Christianity. . . . . . . . 56

Non-reproducible Church Models . . . . . . . . . . . . . . 56

Subsidies Creating Dependency . . . . . . . . . . . . 56

Linear, Sequential Thought and Practice . . . . . . . . . . . 57

Planting "Frog" Rather than "Lizard" Churches . . . . . . . . . . 57

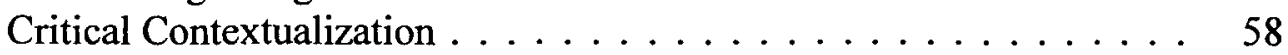

Contextualization Defined . . . . . . . . . . . . 58

Syncretism. . . . . . . . . . . . . . . . . 60

Critical Contextualization. . . . . . . . . . . . . 61

Reject the Old . . . . . . . . . . . . . 61

Accept the Old . . . . . . . . . . . . . . . 63

Deal with the Old . . . . . . . . . . . . . 63

Summary. . . . . . . . . . . . . . . . . . . . 64

Keep that which is not Unbiblical . . . . . . . . . . . . 64

Reject that which is Unbecoming for Christians . . . . . . 65

Modify Practices to Give Them Explicitly Christian Meaning 65

Reject Current Unbiblical Practices and Replace Them . . . 65

Adopt Rites Drawn From Christian Heritage . . . . . . . . 65

Create New Symbols and Rituals . . . . . . . . . . . . . . 66

Reaching the Muslims . . . . . . . . . . . . . . . 66 
Brief Islamic History. . . . . . . . . . . . . . . . . . 66

Terminology . . . . . . . . . . . . . . . 67

Islam in Northern Nigeria . . . . . . . . . . . . . . . . . 68

Main Islamic Beliefs . . . . . . . . . . . . . . . . . . . 69

Six Articles of Faith . . . . . . . . . . . . . 70

The Five Pillars of Faith. . . . . . . . . . . . . . . 71

Resistance to Christianity . . . . . . . . . . . . . 71

Muslim Evangelism . . . . . . . . . . . . . . . 73

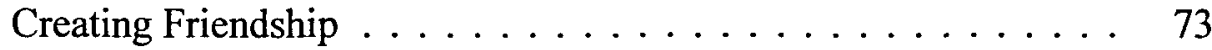

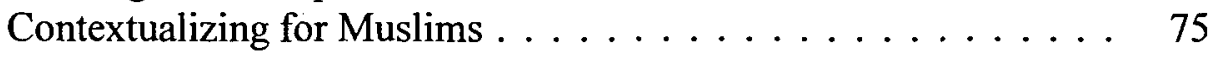

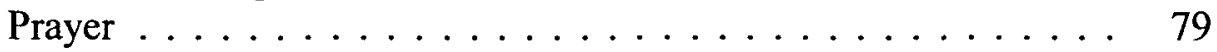

Summary. . . . . . . . . . . . . . . 81

\section{METHODOLOGY FOR CHURCH PLANTING STRATEGIES IN}

NORTHERN NIGERIA. . . . . . . . . . . . . . . . . . 82

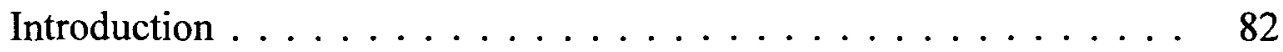

Demography of Northern Nigeria . . . . . . . . . . . . . 82

History and Demography of the Target Group(s) . . . . . . . . 85

The Atyap Community and Culture. . . . . . . . . . . 86

History . . . . . . . . . . . . . . . . 87

Historical Background of the Seventh-day Adventist Work in Northern Nigeria . . . . . . . . . . . . . . . . . . . . . 87

Christian Missionary Rivalry . . . . . . . . . . . . . . . . 88

Establishment of the SDA Mission. . . . . . . . . . . . . . . 90

The Development of the Adventist Mission Work. . . . . . . . . 91

Reorganization into Two Missions. . . . . . . . . . . . . . 92

Discovering the Presence of Other Religious Groups in Nigeria . . . . . 95

Christianity . . . . . . . . . . . . . . . . . 95

Islam. . . . . . . . . . . . . . . . . . 95

Chrislam . . . . . . . . . . . . . . . . 96 96

A Contextualized Church Planting Strategy . . . . . . . . . . 97

Historical Mandate . . . . . . . . . . . . . . . . . . . . . . 98

Objective of Contextualization . . . . . . . . . . . 98

The Importance of Contextualization . . . . . . . . . . . . . . 98

Issues in Contextualization . . . . . . . . . . . . . . . . . 99

Historical Case For and Against Contextualization. . . . . . 99

Over-Contextualization . . . . . . . . . . . . . 100

Under-Contextualization . . . . . . . . . . . . . . . 100

Critical Contextualization . . . . . . . . . . . . . . . . . . 101

Implementation of Critical Contextualization in Northern Nigeria . 102

A Design for Muslim Evangelism in Northern Nigeria . . . . . . . 103

Friendship Evangelism . . . . . . . . . . . . . . . . . . 103

Friendship . . . . . . . . . . . . . . . . . . . . . . 104

Knowledge and Information . . . . . . . . . . . . 105

Hospitality . . . . . . . . . . . . . . . . . . . . . 105 
Listen and Learn . . . . . . . . . . . . . . . . 106

Personal Conversations . . . . . . . . . . . . . . . 106

Loss of Face Can Mean Loss of Faith . . . . . . . . . . 106

Avoid Criticism . . . . . . . . . . . . . . . . . 107

Relationships between Sexes. . . . . . . . . . . . . . 107

Learn Their Language and Culture . . . . . . . . . . . . 108

Felt Needs . . . . . . . . . . . . . . . . . . 108

Use of Literature . . . . . . . . . . . . . . . . . . . . . . 109

Fruitful Practices among Muslims. . . . . . . . . . . . . . . . 109

Bible Storying. . . . . . . . . . . . . . . . . . . 112

What Is Bible Storying? . . . . . . . . . . . . . . 112

Objectives of Bible Storying . . . . . . . . . . . . . . 113

Prayer . . . . . . . . . . . . . . . . . . 113

Description of Mission Strategy and Implementation . . . . . . . 114

Training Program . . . . . . . . . . . . . 115

Seminars . . . . . . . . . . . . . . . . . 115

Christian Denominations' Methodology . . . . . . . . . 116

Training of Global Mission Pioneers . . . . . . . . . . . 116

Conference Support . . . . . . . . . . . . . . . . 117

Meeting the Financial Cost . . . . . . . . . . . . . . 117

Development of Relationship with Community Leaders . . . . . 120

Information to the Community. . . . . . . . . . . 120

Invitation to Community Leaders . . . . . . . . . . . 120

Issues that are Important . . . . . . . . . . . . . . . . 121

Series for Community Leaders. . . . . . . . . . . . . . 121

Meeting with Small Groups . . . . . . . . . . . . . . 122

Summary . . . . . . . . . . . . . . . . . 122

V. SUMMARY, CONCLUSION, AND RECOMMENDATIONS $\ldots \ldots .124$

Summary. . . . . . . . . . . . . . . . . . . . . 124

Reasons for Planting Churches . . . . . . . . . . . . . . . 125

Strategies for Church Planting . . . . . . . . . . . . . . . 125

Reaching the Muslims in Northern Nigeria . . . . . . . . . . . 126

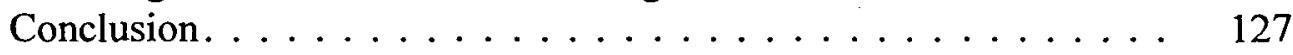

Recommendations . . . . . . . . . . . . . . . 128

Appendix

A. CONFERENCE AND MISSION STATISTICS $\ldots \ldots \ldots \ldots \ldots$

B. INTERVIEW QUESTIONS . . . . . . . . . . . . . . 140

C. TRAINING SESSION FOR 28 GLOBAL MISSION PIONEERS . . . . 143

D. CORE BIBLE STORY LIST $\ldots \ldots \ldots \ldots \ldots \ldots \ldots$ 


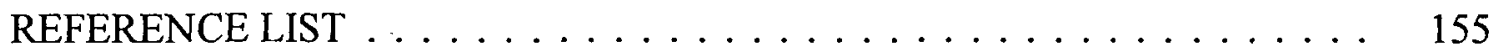

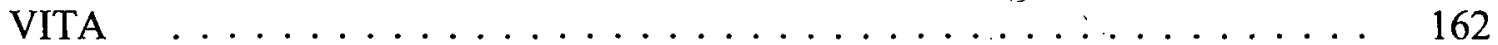




\section{LIST OF FIGURES}

1. Map of Northern Nigeria . . . . . . . . . . . . . . . . . . . 84

2. Northern Nigeria Mission Membership (1948-1993) . . . . . . . . . . . 92

3. Northern Nigeria Mission Organized Churches (1948-1993) . . . . . . . . . 93

4. North-east Nigeria Conference Membership (1993-2008) . . . . . . . . . . . 94

5. North-west Nigeria Conference Membership (1993-2008) . . . . . . . . . . 94

\section{LIST OF TABLES}

1. Northern Nigeria Census Figurés $(2007) \ldots \ldots \ldots \ldots$. . . . . . 83

2. Nigeria: Facts and Figures . . . . . . . . . . . . . . . 97

3. Budgetary Income Planting Project. . . . . . . . . . . . . . . . 119 


\section{LIST OF ABBREVIATIONS}

ASWA

COCIN Church of Christ in Nigeria

CMS

DO

ECWA

FCT

GC

LGA

NA

NENC

NNM

NWNC

NWNUM

RCM

SDA

SIM

SUM

WAD
Adventist Seminary of West Africa

Church Missionary Society

Divisionál Officer

Evangelical Church of West Africa

Federal Capital Territory

General Conference

Local Government Area

Native Authority

North East Nigeria Conference

North Nigeria Mission

North West Nigeria Conference

North Western Nigeria Union Mission

Roman Catholic Mission

Seventh-day Adventist Church

Sudan Interior Mission

Sudan United Mission

West-central Africa Division 


\section{ACKNOWLEDGEMENTS}

I humbly wish to acknowledge the contributions of the following people and organizations:

I am thanking the executive committee of the North-east Nigeria Conference for the study leave granted me to undertake this course of study.

I thank the North-American Division of the Seventh-day Adventist Church for the financial assistance it granted me to enable me complete this program.

I truly appreciate the contributions of the International Student Service Director, Dr. Najeeb Nakhle.

I cannot thank Rita Pusey enough for her wisdom and motherly counsel she provided during these hard times. May she remain blessed!

I thank Yvonna Applewhite for her constant reminders. She is indeed a concerned and trustworthy lady.

I appreciated the contributions of the leadership cohort coordinator, Dr. Stanley Patterson. He is not only a teacher, but a friend who cares. His last words to us in the class were, "You have to love the people you lead." He truly demonstrates his love for his students.

Bonnie is a befitting aunt. I thank her for helping me type and format some chapters of this project. May she remain blessed accordingly.

I thank Dr. Jeanette Bryson. She is a mother indeed! She demonstrated her concern for my success. Thank you, Nana. 
I thank my advisors, Dr. Bruce Campbell Moyer and Dr.Kenley Hall for their willingness to allow me tap from their well of experiences. They provided the time to read and make necessary adjustments to this project dissertation; I am indeed grateful to them.

Finally, I thank God for His care. I praise His name forever. 


\section{CHAPTER 1}

\section{INTRODUCTION}

\section{Personal History}

I was born on September 15, 1953, the youngest of seven children. The first religious movement I ever witnessed was Islam, although my parents did not embrace it. Thus, my first fifteen years were spent with my parents as an unbeliever. My parents, being farmers, had little or no interest at all in western education. As a result, I spent my childhood as a farmer.

Unfortunately, there was no school close by to enable me to obtain a formal education. However, at age fifteen, I could make decisions for myself, thus I decided to look for the school nearest our home town. I discovered the school was about twenty miles away. I found out later that it was a Roman Catholic mission school. It was also during this period that I first heard of Christianity. I spent six years learning Boko (western education). By the grace of God, at the age of twenty-two, I was one of the first groups of young men from my home town to obtain formal education. I succeeded in gaining admission to the government high school in town in 1974, and it was during this period that I came in contact with Seventh-day Adventist students. I was baptized and joined the church in June 1978. Since I joined the Seventh-day Adventist Church, I have never regretted doing so at any moment. Almost on a daily basis I get enlightenment. 
After graduation from high school in 1979, I married my wife, Tani, who has being a true companion in ministry. The Lord has blessed us with three boys and three girls.

I became a civil servant in 1980 , and, by 1985 , I felt called into fulltime ministry. Unfortunately, I resisted this call for five years. But I thank God for His patience with me. God still wanted to fulfill His purpose for my life and, by November 1990, I answered the call to fulltime ministry. The church has supported my studies right from undergraduate to this level.

The Seventh-day Adventist Church has granted me the opportunity to serve as a church pastor, district leader, conference departmental director (two times), conference evangelist, and secretary, respectively. While I served as a conference secretary and evangelist, I was motivated and challenged to become equipped for the ministry, which is the reason I chose to undertake this course of study. My greatest interest is learning the techniques and strategies for reaching the unreached people of North Nigeria with the gospel of salvation. Although I am majoring in leadership, my project dissertation is centered on church planting, an area about which I am passionate.

\section{Statement of the Problem}

The first Adventist missionaries came to Northern Nigeria in 1930. Their intent to establish medical and evangelistic work in Zangon Kataf District in Southern Kaduna was restricted by three opposing factions: the Sudan Interior Mission, Islam, and African Traditional Religion. Islam is a fast growing religion in Nigeria, particularly in the northern region. This constitutes a big challenge to the Seventh-day Adventist Church. Catholicism was so foreign to the thinking of the indigenous people; it frustrated the efforts of missionaries from other denominations. Eighty years later, there is still no 
Adventist presence in this area, a part of the $10 / 40$ window that encompasses all of Northern Nigeria.

Although there are several Adventist health and educational institutions in contact with both Muslims and the indigenous people of the north, the Adventist Church still faces tremendous difficulties in winning them to Christ. During these years we have not been able to establish any churches in this region. There is therefore a need to develop a church planting strategy for the Seventh-day Adventist Church in Northern Nigeria.

\section{Purpose of the Project}

The purpose of this project dissertation is to develop a strategy for church planting for the Seventh-day Adventist Church in Northern Nigeria, beginning in the Zangon Kataf District of Southern Kaduna.

This project dissertation will help develop my church planting knowledge and skills. It will help me contribute to the introduction of a Christian culture in the Northeast and Northwest Conferences of Northern Nigeria conducive to the planting of new Adventist churches, which are both biblically faithful and culturally relevant. I hope and pray that this project will also encourage prospective church planters to commit their lives to the planting of new churches that will reap a great harvest of souls for the kingdom of God.

Having read through church growth literature, I am convinced that it is easier to reach the unchurched by planting new churches rather than by attempting to transform traditional ones. Alalade $(2008$, p. 171) observes that in Nigeria today, the fastestgrowing denominations are the ones with the most aggressive church planting programs. An effective church growth strategy, therefore, is to keep planting new churches rather 
than renovating the existing ones. It is also recognized that new congregations can not only be more effective in reaching specific people groups outside the walls of our churches, but also add life to those on the inside.

\section{Justification for the Project}

For the past 80 years, the desire of J. J. Hyde, W. McClements (1931), and the mission of the Seventh-day Adventist Church has not been fully realized. Although the foundation they laid led to the formation of the Northeast and Northwest Nigeria conferences, with a combined membership of about 40,000 , no church has been established in this region.

Other missions (the Roman Catholic, Anglican, Baptist, ECWA, COCIN, and numerous Pentecostal bodies) are firmly established in this area. There is, therefore, an urgent need to revisit the mission of the church in Northern Nigeria and Southern Kaduna in particular, beginning in Zangon-Kataf. It is a known fact that there is a strong resistance from Islam and traditional beliefs, yet there is dire need for the proclamation of the gospel.

The use of doctrinal methods for evangelism and church planting has been in place since the beginning of the work in Northern Nigeria. This project dissertation is designed for the purpose of bringing about a remarkable variation in church planting strategies in this region.

\section{Expectation from the Project}

This project will potentially provide new life for church planting in Northern Nigeria. Its implementation will increase my knowledge in mission and quality of my personal spiritual well-being. In addition, the project will provide contextualized church 
planting concepts that may potentially be beneficial to others and serve as a source of motivation for mission. The implementation of this project will, in a great measure, contribute to the fulfillment of the gospel commission in Matthew 28:19, 20

Finally, the establishment of a church planting strategy for the Seventh-day Adventist Church in Northern Nigeria will begin to fulfill the mission of the pioneering missionaries. As Nengel (2005) observed, after studying the prospect of global mission, and speaking of North Nigeria, this area is " the best opening for church planting and the Seventh-day Adventist Church global mission" (p. 8).

\section{Limitation of the Project}

This church planting project is regional in scope. Although the basic principles are likely transferable to other parts of Nigeria and elsewhere, this strategy for church planting has been specifically designed for the Seventh-day Adventist church in Northern Nigeria only. Some of the information in this research has not been tested, but will be at the time of implementation.

\section{Definitions of Terms}

Abwoi: This is the traditional religion of the Atyap community. It is secretive in nature and only those who have been initiated have access to it.

Akwai gishiri sakanin mu: AHausa/Fulani statement that means, "There is salt between us." This means that now that we have eaten together, we have become friends.

Boko: It is a Hausa/Fulani term that means "western education"

Boko-Haram: An obscure Muslim fundamentalist sect opposed to western education and seeks to have Shariah law implemented throughout Nigeria. 
Emirates: This is the term used for chiefdoms among the Hausa/Fulani in Northern Nigeria.

Emirs: These are titles that apply to traditional chiefs within the Islamic faith among those who have embraced Islam in Northern Nigeria.

Isa: A reference to Jesus among the Hausa/Fulani Muslims in Northern Nigeria.

Jigger: A local epidemic that commonly plagued the indigenous people in the 1930s in Northern Nigeria.

Leadership: A relational process engaged in by two or more people who are freely associated in the pursuit of a common purpose. The gifts and skills of each contribute to the process of moving toward the accomplishment of a common goal or purpose.

Mission or ministry: Mission is what the Christian does for those outside the body of Christ, whereas ministry is our service to those inside the body of Christ.

Purdah: A curtain or screen used to seclude women. Muslims in Northern Nigeria practice this system of seclusion by keeping their women indoors throughout the day time. They have freedom only at night. This is the only time they are allowed to visits their friends and relations.

Sabon Gari: Settlements for Christian traders and civil servants who come from the southern parts of Nigeria and all non-Christian immigrants to the northern part of Nigeria.

Tyap: The language commonly spoken by the Atyap community who occupy most part of Zangon-Kataf local government area. 
Vigilantes: Volunteers who accompany the police for night patrols. They are especially useful in places where there is armed robbery at night.

Zana: Weaved grass materials used for thatched houses and fence making in most parts of Northern Nigeria.

10/40 Window: That area of the world from ten to forty degrees north of the equator.

\section{Methodology}

A qualitative method using descriptive statistics will be used to develop this project dissertation. Demographic data of Northern Nigeria will be collected and analyzed. A profile of the people groups in Zangon Kataf area will be developed. Topics related to church growth will be explored in the writings of Ellen G. White and significant missiologists. Current literature will be reviewed. This will include books, journals, and articles on church planting strategies, critical contextualization, and Muslim evangelism. Based on the research, a strategy for church planting will be developed for the Seventh-day Adventist Church in Northern Nigeria, beginning in Zangon Kataf.

\section{Organization of the Study}

Chapter 1 presents a brief introduction to my personal journey and the background of Adventism in my home district of North Nigeria. Also included is a statement of the problem, justification for the project, expectations, limitations, definition of terms, and an explanation as to the methodology. Chapter 2 explores biblical principles for church planting, the mission strategies of the early church, and Ellen White's counsel on church planting, in order to develop a theological foundation for a church planting strategy in Nigeria 
Chapter 3 explores and reviews church planting strategies in three segments: The first segment focuses on general church planting strategies. The second section examines literature on critical contextualization, exploring the process of making the biblical text and its content meaningful and applicable to the thought patterns and situations of the followers of Islam in Northern Nigeria and the Atyap people of Zangon-Kataf in Southern Kaduna in particular. The third segment reviews literature on Muslim evangelism. It describes briefly the history and expansion of Islam in Northern Nigeria, identifying who they are, where they come from, and how they can be reached.

Chapter 4 gives a brief history and demography of Northern Nigeria, with particular attention to the target groups (the Atyap, Baju, Hausa/Fulani, Ikulu and Kamantong), the indigenous people that occupy Zangon-Kataf area of southern Kaduna. It includes the historical background of the Seventh-day Adventist work in Northern Nigeria. In addition, the chapter takes note of the presence of other major religious organizations in the area under consideration. It ends with contextualized church planting strategies among the Muslims in Northern Nigeria beginning at Zangon-Kataf.

Chapter 5 summarizes the project dissertation, draws conclusions, and suggests recommendations. 


\section{CHAPTER 2}

\section{THEOLOGICAL FOUNDATION FOR CHURCH PLANTING}

\section{Introduction}

Rankin (2006, p. 15) believes that the vision that guides each individual who serves God must be shaped by a commitment to fulfilling God's will and purpose. Likewise, the vision that guides a church in the world must be consistent with God's purpose. It is God's purpose for the entire world to have an opportunity to know and worship Him. Jerry Rankin spent 23 years as a missionary in Asia until he became International Mission Board president in 1993. He led the Board with a vision of missionaries, churches, and volunteers partnering to take the gospel to all peoples.

The most familiar verse in the Bible states, "For God so loved the world that $\mathrm{He}$ gave His only begotten Son, that whosoever believes in Him shall not perish but have eternal life" (John 3:16). The world here includes people in dusty, remote villages in Africa, where people are held in bondage to their charms and fetishes and where thousands of people die of AIDS daily. It includes millions of people in India, most of who bow before lifeless Hindu idols in a futile search for blessings and enlightenment. It includes multitudes of Muslims across northern Africa, the Middle East, and Central Asia, declaring their belief in Allah and Muhammad as his prophet in a fatalistic faith that offers no hope and assurance. 
Church planting has become an important tool in spreading the gospel of Jesus Christ and His kingdom. This chapter will investigate biblical principles for church planting, the mission strategies of the early church, and Ellen White's counsel on church planting, in order to develop a theological foundation for a church planting strategy in Nigeria. Scripture quotations, unless otherwise indicated, are from the New King James Version of the Bible.

\section{Biblical Principles for Church Planting}

\section{Church Planting Defined}

In an attempt to define church planting, it is imperative that the entity that is to be planted - the church-is addressed. The Encyclopedia Americana (1988, p. 694) gives several meanings of the English word church, which embraces a variety of concepts. The word church in its most limited meaning denotes a building in which Christians meet for religious worship. In a wider sense, it denotes a variety of relationships, ranging from that of a group of Christians professing a particular creed to the whole body of faithful, either in the practice of their faith or in their dealing with the state.

Walter (1996) adds that the New Testament word for church is ecclesia, which means "the called out ones" (p. 95). Predominantly, ecclesia applies to a local assembly of those who profess faith in and allegiance to Christ. Second, ecclesia designates the universal church (Acts 8:3; 9:31; 1Cor 12:28; 15:9; Eph 1:22-23; Col 1:18). Third, the ecclesia is God's congregation (1 Cor 1:2; 2 Cor 1:1). The Bible portrays the church as a divine institution, calling it "the church of God" (1 Cor $1: 2 ; 10: 37)$ or "the church of Christ" (Rom 16:16). These expressions with a distinctive Christian meaning are 
provided by the apostle Paul. He sets the Christian assembly/gathering/committee apart from all other secular or religious groups.

In this project, my objective is to develop a strategy for gathering Christian believers into new visible believer groups or churches for the purposes of worship, fellowship, instruction in the word, the celebration of the Lord's Supper, service to mankind, and worldwide proclamation of the gospel. The process of beginning and growing new local churches according to the gospel commission (Matt 28:18-20) and Jesus' statement in (Matt 16:18), is what is termed "church planting" in this study. For the church (ecclesia) is built on Christ who is the foundation.

Osei (1997, p. 17) understands the term "church planting" as metaphorical, involving as it does the thought of a gardener who plants seeds in the earth. The seed germinates, bursts into tender plants, and grows through the natural process to yield much fruit. Such is the case of a new church. It is started in a given locality, grows through Bible study and prayer, and matures through the propagation of the gospel. When new group of Christian converts is formed, it becomes a planted church, a new body in Christ, according to the Scriptures (Eph 5:23,30; Col 1:24). Through each newly planted congregation, God extends His salvation to others. In this light, Burrill (1999) writes, "Church planting was the primary evangelistic activity of the earliest Christians, as well as the fledgling Adventist community. Is it still an option today for effectively evangelizing lost communities?"'(p. 91). In like manner, church growth guru Wagner (1990, p. 11) believes that the single most effective evangelistic methodology under heaven is planting new churches. With Wagner's quote in mind, my endeavor here is to establish a biblical and Spirit of Prophecy foundation for church planting. 


\section{The Mission of Christ on Earth}

Jesus explained His mission to the twelve apostles. "For even the Son of Man did not come to be served, but to serve, and to give His life a ransom for many" (Mark 10:45). If anyone had a right to be served, it was Jesus. He is God, King of kings, and Lord of lords. Millions of angels serve Him day and night. However, when Jesus came to earth, He came to serve others and give His life as a ransom for sinners. The Greek word for "ransom" is lutron. It is a noun from luo, "to loose." Lutron is a ransom or a price paid for redeeming captives, loosing them from their bonds and setting them at liberty. The books of Matthew (20:28) and Mark (10:45) apply the term spiritually to the ransom Christ paid to the Father for delivering people from the bondage of sin and death.

\section{John Writes about Christ's Mission}

Some scholars believe that John the apostle wrote the gospel of John. He also wrote $1^{\text {st }}, 2^{\text {nd }}$, and $3^{\text {rd }}$ John and the book of Revelation. Although the Bible does not tell us who this John was, most early historical sources identify him with the John of the Gospels, brother of James, son of Zebedee, a disciple of Jesus (Matt.4:21-22; 17:1 Mark $3: 17 ; 10: 35-41$ Luke 9:28,54; 22:8; John 13:23-25; 18:15-18). In 1 John 4:9-10, he wrote, "In this the love of God was manifested towards us, that God has sent His only begotten Son into the world, that we might live through Him. In this is love, not that we love d God, but that He loved us and sent His Son to be the propitiation for our sins." That is the mission. God the Father sent God the Son to be the propitiation for our sins. 


\section{Christ's Mission in the New Testament}

Jesus came to earth with a mission to bring people to His heavenly Father. He revealed this when He prayed in the gospel of John (17:3-4), "And this is eternal life, that they may know you, the only true God, and Jesus Christ whom you have sent, I have glorified you on earth, I have finished the work which you have given me to do." The work Jesus completed was the mission God the Father had given Him to do.

The following is one more insight into Christ's mission: "But when the fullness of time had come, God sent forward His Son, born of a woman, born under the law, to redeem those who were under the law, that we might receive the adoption as sons. And because you are sons, God has sent forth the Spirit of His Son into your hearts, crying. out, "Abba, Father" (Gal 4:4-7). We see here the beautiful arrangement the Trinity has in saving people from their sins. God the Father sent His Son to redeem those under law that we might receive the full rights of sons. God the Father and the Son sent God the Holy Spirit into our hearts to make us sons and heirs.

\section{Christ Came to Establish His Church}

Potts $(2009$, p. 8) explains that with intentionality, Jesus went about the task of establishing His church—His ecclesia, "the called out ones." Jesus established a community of believers who would carry on with His mission after He had returned to heaven. Much of His public ministry was invested in developing the people who would lead the church after He was gone. To them, He made this promise, "And I will give you the keys of the kingdom of heaven, and whatever you bind on earth will be bound in heaven, and whatever you loosed on earth will be loosed in heaven" (Matt 16:19). Christ Himself determined the purposes of the Church. 
In the Great Commission, Jesus communicated three further purposes. He declared, "Therefore go and make disciples of all nations, baptizing them in the name of the Father and of the Son and of the Holy Spirit, and teaching them to obey everything I have commanded you" (Matt 28:19-20). Christ commissioned His Church to make disciples, baptize, and teach. To make disciples is evangelism. Christ's followers are called to belong, not just believe. Christ also desires His Church to teach new believers to obey all that He commanded them (Matt 28:19-20). This final purpose of the church is about helping people mature and become fruitful in their faith. The term often used for this is "discipleship."

\section{The Gospel Commission}

According to the missionary mandate, we are to "make disciples of all nations" (Matt 22:19), which includes all people groups in the world. The New Testament suggests that the most effective method for doing it has been planting new congregations. Christ said, "But you will receive power when the Holy Spirit comes on you; and you will be my witnesses in Jerusalem, and in all Judea and Samaria, and to the ends of the earth" (Acts 1:8). This mandate shows that the focus of church planting should be both local and global. With His parting words, Jesus focused the leaders of His church on the task of making disciples. He declared, "All authority in heaven and on earth has been given to me. Therefore go and make disciples of all nations" (Matt 28:18, 19). This was to be their mission. In this commission Jesus focused the early church on the priority of the mission mandate of making disciples.

By commanding the disciples to "go," Jesus indicated that He was organizing His church for the purpose of mission. The church was not to wait for people to come to her. 
She was to "go." Burrill (1996, p. 48) adds that the New Testament church clearly understood that its reason for existence lay in the making of disciples among all the nations. The priority of mission was the overwhelming purpose of this early church. In fact, the early church cannot be understood aside from their mission consciousness.

It is noteworthy that the Great Commission focused the apostles on the task of making disciples of "all nations." Every ethnos, every people group, was to be evangelized. Inherent in the Great Commission was the strategy of planting new churches within each people group.

Osei (1997, p. 25) likewise observes that the command to "make disciples" is a sure instruction that leads to multiplication (of new believers). This is the key to reaching out into new areas to make more converts. Multiple groups of these new converts are an obvious result and the ultimate objective of evangelizing new areas. New disciples cannot be made without grouping the people being disciple. Since church planting is primarily concerned with making disciples and grouping them to become part of the "body of Christ," which entrusts them with the proclamation of the kingdom of God in every segment of society and in every culture and language of man, it fulfills this divine imperative.

\section{Reasons for Planting New Churches}

Palla (1994, pp. 7-10) gives seven solid reasons for planting new churches.

1. Jesus commanded it. Jesus said, "Go therefore and make disciples of all the nations, baptizing them in the name of the Father and of the Son and of the Holy Spirit, teaching them to observe all things that I have commanded you; and lo, I am with you always, even to the end of the age" (Matt 28:19,20). 
2. It is a New Testament norm. Church planting is the New Testament way of spreading the gospel. Disciples of Christ practiced it. Planting churches in Asia Minor and Europe was an implementation of the Great Commission. Hesselgrave (1980, p. 33) notes that there is an intimate relationship between gospel proclamation and church planting; they cannot be divorced without doing violence to the mission of the church.

3. It is efficient. Peter Wagner (1990, p. 11) observes that the single most effective evangelistic method under heaven is planting new churches. Growth of the new cells is faster and healthier than of the older body. New churches thrive with life. Wagner says that, without exception, the growing denominations have been those that stress church planting. New congregations are most effective in reaching the unreached and better in giving. New churches provide more options for the unchurched. They usually are more sensitive to the needs of the community, more relevant, and assimilate new members more easily.

4. It is natural. The biblical account of the creation establishes a principle of reproduction "according to their kind" (Gen 1:12) both for vegetation (Gen 1:12) and for animals (Gen 1:24). Apple seeds beget apple trees and sheep beget sheep. James Feeney (1988) writes that "Witnessing Christians, sowing the precious seed of the Word of God, facilitate the conversion of additional souls to Christ. By the same token, churches reproduce churches!" (p. 9).

5. It is necessary. (a) It is needful for denominational survival and growth. Schaller $(1979$, p. 352$)$ states that every denomination reporting an increase in the total number of congregations reports an increase in members. Every denomination reporting a decrease in congregations reports a decrease in members. The first step, then, in 
developing a denominational strategy for church growth should be to organize new churches. (b) To meet the changing needs people have. People are different, even in the same homogenous unit. They differ in taste, behavior, attitude, and needs, which change from year to year and from generation to generation. Unfortunately, older churches cling to the traditional forms as they would be a part of the message. And like human beings, as they age they generally lose the power to reproduce.

6. It develops people. New missions help to accommodate church leaders looking for new challenges, and create room for potential leaders to grow. Ellen White (1948b, p. 244) in Testimonies to the Church (vol. 8) observes that trees that are planted too tightly do not flourish. They are transplanted by the gardener that they may have room to grow and not become dwarfed and sickly. The same rule would work well for our large churches. Many of the members are dying spiritually for want of this very work. They are becoming sickly and inefficient. Transplanted, they would have room to grow strong and vigorous.

7. It brings renewal and stimulation into existing churches. New churches bring personal and corporate spiritual revival, because planting a church is the cutting edge of religious experience. It creates enthusiasm in the mother church, motivates them, and helps to cultivate a missionary spirit as well as eliminating selfishness.

\section{The Missionary Strategy of the Early Church}

Hesselgrave (1980, p. 58) has indicated a clear mission strategy of the church as illustrated by the church planting endeavors of the apostle Paul. The church commissioned missionaries to plant churches (Acts 13:1-4; 15:39-40). Church planters contacted the audience they hoped to reach (Acts 13:14-16;14:1). Church planters 
communicated the gospel to receptive people (Acts 13:16-41). The new believers were congregated (Acts 13:43) and established in the faith (Acts 14:21-22). Leaders were appointed in the new churches (Acts 14:23). Once leadership was fully transferred to the new leaders, the church planters left (Acts 16:40). The book of Acts clearly documents the fact that the early church was organized for mission.

The early church was truly a missionary movement. The book of Acts reveals the key elements of the church's mission strategy: the ministry of the Holy Spirit, earnest prayer, evangelism, church planting, holistic small groups, and empowering leadership.

The Ministry of the Holy Spirit

The ministry of the Holy Spirit in the establishment of new churches in the New Testament gives evidence of a solid biblical basis for church planting, for the Holy Spirit was involved in the whole missionary thrust of the apostles, and the planting of churches began. At first, Jesus told the disciples not to depart from Jerusalem but to wait for the promise of the Holy Spirit (Acts 1:4,5). He said, "But you shall receive power when the Hóly Spirit has come upon you; and you shall be witnesses to me in Jerusalem, and in all Judea and Samaria, and to the end of the earth" (Acts 1:8). The key to the success of the work of the disciples did not reside in their own abilities and strengths. Hodges (1957) notes, "Methods alone, even correct methods, will not produce a New Testament church. The enabling power of the Holy Spirit caused the disciples to spread the gospel and plant churches" (p. 97). Young (1979) also supports the idea of church planting:

New churches are born periodically because the Holy Spirit of God is still at work in God's world. Indeed, apart from the work of the Holy Spirit there would be no new churches or any old churches either. The Holy Spirit is the life of the church; he is the One who gives life and vitality to the church.... He is the heartbeat of the church which the New Testament describes as the body of Christ. The Holy Spirit is the source of growth of the church, both intensively and extensively.... He is 
responsible for the church duplicating itself in the birth of new church congregations, as well as winning new converts to Christ. (pp. 163-164)

Even during the persecution it is evidenced that through the power of the Holy Spirit the church successfully moved on. And after the persecution, "Then the churches throughout all Judea, Galilee, and Samaria had peace and were edified. And walking in the fear of the Lord and in the comfort of the Holy Spirit, they were multiplied" (Acts 9:31). Thus, the multiplication of the churches was accomplished in the empowerment of the Holy Spirit and in the fear of the Lord.

Within the church, the Holy Spirit worked (and still works), bestowing special gifts (Rom 12:6-8; 1 Cor 12:4-11; Eph 4:11; 1 Pet 4:11) upon the church for edification and empowerment as well as for the perfecting of the saints (Eph 4:12). In addition, the Holy Spirit led the members of the church into Christian ministry to produce the fruit of the Spirit (Gal 5:22-23).

In the outreach missionary thrust of the apostles, the Holy Spirit directed and even singled out some individuals (Acts 13:3-5) from the congregation of Antioch to a ministry of church planting. The Holy Spirit directed the members of the church where they should work (Acts 16:6-9; 8:26, 27, 39, 40) and provided the direction and motivation necessary to accomplish the task (Acts 13:1-3). The Holy Spirit is as concerned today with planting new churches as He was in the days of the first faltering steps of the church.

\section{Earnest Prayer}

Rohrmayer (2006, p. 30) believes that God shapes the world by prayer. The more praying there is in the world, the better the world will be, the mightier the forces against evil. The prayers of God's saints are the capital stock of heaven by which God carries on 
His great work upon the earth. God conditions the very life and prosperity of His cause on prayer.

As we glean from Paul's letters written to churches and individuals that prayed for him and his church planting ministry, we discover a couple of interesting insights.

1. Paul developed prayerful relationships with fellow believers. Paul writes to the believers in Corinth affirming God's power in delivering him from some sort of neardeath experience while encouraging them to be part of his future deliverances by praying for him. He writes, "He has delivered us from such a deadly peril, and he will deliver us. On him we have set our hope that he will continue to deliver us, as you help us by your prayers. Then many will give thanks on our behalf for the gracious favor granted us in answer to the prayers of many" $(2$ Cor 1:10,11).

Prayer is a mystery. God does not need our prayers to deliver His servants, but God wants His people interceding for His servants. Praying for one another is one practical way to develop a deep sense of community throughout the body of Christ and it is also a way for God's people to share with a sense of gratitude in God's provision. Paul had a prayer relationship with the church at Corinth that was based on giving and receiving. He asked them to pray for him and he reminded them of his prayers for them (2 Cor 13:7-9).

2. Paul made specific requests of prayer to fellow believers. In the book of Ephesians 6:19-20, we see that Paul asked specifically for the church to pray for him. He was not shy in this matter and he went on in more detail, "that utterance may be given to me, that I may open my mouth boldly to make known the mystery of the gospel, for 
which I am an ambassador in the chains; that in it I may speak boldly, as I ought to speak."

3. Paul shared their personal pain and joy. The third insight we find is that Paul was not afraid to share his struggles, fears, and pain, along with his profound sense of confidence in God's power and presence in his life. In Paul's second letter to Timothy, he bares his hurts and disappointments by writing, "Alexander the metalworker did me a great deal of harm. The Lord will pay him for what he has done... At my first defense, no one came to my support, but everyone deserted me. May it not be held against them" (2 Tim 4:14, 16). Paul did not only share the pain but he also intimately shared his great resolve and confidence that God was with him.

\section{Relentless Evangelism}

Potts (2009, p. 16) explains that evangelism was the main focus of the early church. The early believers were radically committed to communicating the gospel and urging people to receive Christ. The disciples were constantly telling people about Jesus. They did it publicly. They did it relationally. And they sought to do it in any way that was relevant to the culture.

\section{Public Evangelism}

On the day of Pentecost, the church grew from 120 believers to 3,120 . In the power of the Holy Spirit, Peter preached boldly to thousands. This public evangelistic sermon launched the Jerusalem church. The public proclamation of the gospel continued to be a key element of the church's evangelistic strategy. The apostles understood that God had called them to prayer and proclamation. As God worked miracles of healing, 
large crowds were attracted and the gospel was preached. Thousands were being converted.

Filled with jealousy, the Jewish religious leaders arrested the apostles and put them in jail. "But at night an angel of the Lord opened the prison doors and brought them out, and said, "Go, stand in the temple and speak to the people all the words of this life. And when they heard that, they entered the temple early in the morning and taught" (Acts $5: 19-210)$

The apostles had a clear mandate from God to keep preaching. This they did fearlessly. Even though Peter and John were arrested again, flogged, and ordered to stop preaching in the name of Jesus, they continued to preach. "And daily in the temple, and in every house, they did not cease teaching and preaching Jesus as the Christ" (Acts 5:42). They were absolutely relentless in their public proclamation of Jesus.

\section{Relational Evangelism}

One study (Arn \& Arn, 1982, p. 38) indicates that, in addition to addressing large crowds in public places, the apostles also taught small groups in private homes. There was a powerful relational element in the witness of the early church. The gospel spread naturally as believers shared their faith with family, friends, and associates - their oikos. "The Gospels, Acts, and Epistles show that the bridges of oikos were used regularly as a means to spread the Good News." For example, Paul's greetings and a solemn farewell in his first epistle to the church at Corinth include that of the church in the house of Aquila and Pricilla (1 Cor. 16:19).

There are numerous examples of relational evangelism in the New Testament. Among them are the demon possessed man (Mark 5:19), Levi Matthew (Mark 2:15), 
Peter (John 1:41), Philip (John 1:45), Cornelius (Acts 10:24); Lydia (Acts 16:15), and the Philippians' jailer (Acts 16:34). Paul modeled relational evangelism in Corinth when he befriended a Jewish couple, Aquila and Priscilla (Acts 18:1-3). Like him, they were tent makers. As Paul worked together with them, they became good friends. Later, Aquila and Priscilla joined Paul on one of his mission trips. The book of Acts reveals that Paul not only preached Christ publicly, he also shared Christ personally with friends.

\section{Culturally Relevant Evangelism}

Christ had commissioned the church to take the gospel to the entire world. He told His followers, "But you shall receive power when the Holy Spirit has come upon you; and you shall be witnesses to me in Jerusalem, and in all Judea and Samaria, and to the end of the earth" (Acts 1:8). Such a global mission required an evangelistic approach which would be culturally relevant to each of the targeted groups. Christ's commission included all nations, all ethnos. Burrill (1996, p. 52) argues that if disciples were to be found among all nations, this meant that Christianity must not be localized in Jerusalem, but transformed into an international movement. This internationalization of the church occurred very quickly in the experience of early Christianity. Within the lifetime of the original apostles, Christianity had already ceased to be a Jewish sect and had become an international movement that appealed across cultural lines.

Burrill (1998, p. 52) explains that the disciples first worked among Jews. They had the same cultural background. In time, however, evangelistic contact was also made with non-Jews. God sent Peter to Caesarea to the home of Cornelius, a Roman centurion. It was there that Peter declared, "In truth I perceive that God shows no partiality, but in 
every nation whoever fears Him and works righteousness is accepted by Him" (Acts $10: 34-35)$.

At this point, the mission became more complicated. Church leaders criticized Peter for eating in the home of a Gentile. However, when they came to believe that God was truly leading them to evangelize the non-Jewish world; there were cultural issues to sort out. The Jerusalem Council (Acts 15) convened for the purpose of figuring out whether or not Jewish customs should be imposed on Gentile believers. Issues such as circumcision needed to be addressed. Once the church had done the hard work of separating culture from the issue of the gospel, the stage was set for Christianity to spread to "the ends of the earth." The internationalization of the church could not have occurred had not Christianity become culturally relevant to the various nations.

Apostle Paul sought to make the gospel culturally relevant wherever he went. $\mathrm{He}$ said, "I make myself a slave to everyone, to win as many as possible. To the Jews I became like a Jew, to win the Jews. To those under the law I became like one under the law (though I myself am not under the law), so as to win those under the law. To those not having the law I became like one not having the law (though I am not free from God's law but am under Christ's law), so as to win those not having the law. To the weak I became weak, to win the weak. I have become all things to all men so that by all possible means I might save some. I do all things for the sake of the gospel" (1 Cor 9:1923).

Paul did not compromise the integrity for the message. However, he did package it in a way that would enable him to reach people of different cultures effectively. $\mathrm{He}$ contextualized his message. In Acts 17, for example, when Paul was speaking with the 
Epicurean and Stoic philosophers in Athens, he used an evangelistic approach that was far different from the approach he took when he spoke to Jews in the synagogues. Paul studied culture. His evangelistic strategy was to present Christ in a way that would connect well with his target audience. Evangelism in the early church was, in truth, culturally relevant.

\section{Church Planting}

The early church spread primarily through church planting. The book of Acts documents the missionary journeys of Paul and his associates as they traveled from place to place raising up new churches. Paul got his first taste of church planting in Syrian Antioch. The first Christ-followers who arrived in Antioch focused on communicating their message to Jews only. However, the Holy Spirit later impressed some other believers to work for the non-Jews living in Antioch. Although these Gentiles lived in the same city, they were culturally very different from the Jews. A different approach was needed to reach them. God blessed the intentional attempt to reach this new people group. "And the hand of the Lord was with them, and a great number believed and turned to the Lord" (Acts 11:21).

Barnabas and Paul ended up in Antioch teaching the new converts and establishing the church. It was exciting work. Great numbers of people were converted. After they had spent a year in Antioch, God sent Barnabas and Paul off on their first missionary journey to plant churches in other cities.

Later in life, Paul confessed, "And so I have made it my aim to preach the gospel, not where Christ was named, lest I should build on another man's foundation" (Rom 15:20). Paul's passion was to plant churches in places where no other Christians 
had previously worked. He would preach, raise up a church, train leaders, and move on to start another church. It was an effective strategy. Paul could proclaim, "From Jerusalem and round about to Illyricum I have fully preached the gospel of Christ"' (Rom 15:19).

Burrill (1998, pp. 37-38) also adds that the early church developed a deliberate strategy to plant culturally sensitive churches in every people group they found. The early church quickly developed into a church planting movement. ... Church planting was not one of many strategies in the New Testament church--it was the only strategy.

\section{Holistic Small Groups}

The early church met for worship in homes. For the first few centuries, Christianity was a home-based movement. The apostle Paul referred to this or that family and "the church that is in their house" (Rom 16:5; 1 Cor 16:19; Col 4:15; Phlm 1:2). He said to the Ephesian elders, "How I kept back nothing that was helpful, but proclaimed it to you, and taught you publicly and from house to house" (Acts 20:20). Burrill (1998, p. 113) observes that Jesus had modeled to His disciples a church that was relational, living together in community as it restored the brokenness of humanity. Out of this family community, evangelism was to occur. With the explosion of Holy Spirit power at Pentecost, the church grew in numbers as well as in spirituality. What was this new community of believers like? Was it just a large group of people who met together every Sabbath to worship God?

Luke states, "Then those who gladly received His word were baptized; and that day about three thousand souls were added to them. And they continued steadfastly in the 
apostles' doctrine and fellowship, in the breaking of bread, and in prayers" (Acts 2:41, 42).

Icenogle (1994, p. 259) observes that this is the earliest description of life in the Apostolic Church. As soon as people were baptized, they immediately got involved in four things: study, fellowship, food, and prayer. Not only were they involved, but Scripture declares that they were devoted to these four things. Two of the four-food and fellowship-are unquestionable group activities. Since these two require a smaller group setting, it is probably safe to assume that the other two activities-teaching and prayer-also occurred in a small group setting. This is further reinforced by the passage that follows:

Now all who believe were together, and had all things in common, and sold their possessions and goods, and divided them among all, as anyone had need. So continuing daily with one accord in the temple, and breaking bread from house to house, they ate their food with gladness and simplicity of heart. (Acts 2:44-46)

It is evidenced in the above quote that the sharing of food was done in homes, which implies that this meeting together was not at all in one place, but in many homes, although the groups also met together regularly at the temple. However, it seems that meetings were primarily in the homes.

The second aspect of life in the early church was fellowship. The believers did not just gather together to study and then leave. Intermingled with their study was time for fellowship. The form of the fellowship is not spelled out in Scripture, but the results are clear. Acts declares that immediately they shared everything in common. They saw the immediate need of providing for one another. Believers willingly sold their own possessions in order to help fellow believers. This is the closest possible kind of fellowship. Jesus had taught that the church was to be a new family, a community that 
healed the brokenness of humankind. The fellowship operating in this early church demonstrated that the teachings of Jesus were at work.

The third aspect of life in the early church was that they ate together. One of the best ways for groups to bond is to eat together. This goes hand-in-hand with fellowship. So great was the fellowship in the early church that these believers ate together every day.

The fourth and fifth aspects of life in the early church are described as prayer time. Praying together builds strong community and spirituality. As people openly share their prayer needs with each other, the group becomes closely cemented. Since prayer occurred in the small groups every day, we can easily imagine that this activity pulled the early believers into the closest harmony.

Burrill (1998, p. 115) observes that this is the church brought forth by the initial evangelization of the disciples at the Pentecost event. It was not a large church in one place, but a church consisting of many groups. The New Testament church of the book of Acts is not a church with small groups, but a church that is small groups. Real fellowship —Konia —was occurring among the disciples.

\section{Spiritual Leadership}

Damsteegt $(2005$, p. 644) indicates that the New Testament provides us the information about the leadership structure of the Christian church. During His ministry on earth, Jesus Christ established the organization and authority of His church. He ordained twelve of His followers to accompany Him on His travels and to prepare them to preach the gospel and heal the sick (Mark 3:14, 15). He also called these twelve men apostles (Luke 6:13). 
White (1940, p. 291) observes that this event was the first step in the organization of the church that after Christ's departure was to be His representative on earth. The calling of these twelve men was of enormous significance. Their office was the most important to which human beings had ever been called, and was second only to that of Christ Himself. As in the Old Testament, the twelve patriarchs stand as representatives of Israel, so that twelve apostles were to stand as representatives of the gospel church.

The book of Acts reveals the next phase in the organization of the church- - the establishment of the New Testament model of church leadership. Soon after Christ's ascension, the apostles became overwhelmed by the demands of the fast-growing church in Jerusalem. To cope with the challenges confronting them, the apostles divided the leadership responsibilities in the local church into two major areas. Seven men were chosen to "serve tables" while the apostle confined themselves "to prayer and the ministry of the Word" (Acts 6:2,4). Both "the seven" and the apostles were involved in serving or ministering, but the manner of their respective involvement differed significantly.

White's (1911, p. 89) comments on these events is very enlightening. She states that under the guidance of the Holy Spirit, the apostles began to outline a plan for the better organization of all the working forces of the church. What was this plan for church organization? This plan established a twofold division of labor between those serving as the spiritual leaders and those taking care of specialized lines of work and the finances of the church. As a result, the church ordained seven men as deacons. By prayer and the laying on of hands, seven chosen men were solemnly set apart for their duties as deacons. 
This was further developed by Apostle Paul, Timothy and Titus, thus setting a pattern for the church. Ultimately form followed function as the churches organized along lines.

In harmony with the leadership model of the Jerusalem Church, the apostles appointed elders as spiritual leaders in every church (Acts 14:23; Titus 1:5). This practice explains why the apostles, when they left Jerusalem to fill their places, did not leave a vacuum in this major center of the church at that time. It also explains the presence of elders in the Jerusalem Church several years later to whom Barnabas and Paul handed their relief contributions for the needy believers in Judea (Acts 11:29, 30).

The next development of church organization took place after the church had rapidly expanded into many regions. Now the Holy Spirit bestowed special spiritual gifts on some of God's people to improve the effective operation of the church. Persons who received these gifts were not to replace the previously elected leadership of elders and deacons, but to work in cooperation with them so that the church would be more successful than ever.

Shortly before his death, Paul, under divine inspiration, gave important instructions to safeguard the leadership structure of the local church. In a letter to Timothy, Paul endorsed the application of the organizational model of the Jerusalem Church to other churches in the world. He carefully spelled out the qualifications for those serving as spiritual leaders (elders) as well as those attending to the other church affairs (deacons) (1 Tim 3:1-13). In a similar manner, Paul instructed Titus to establish order in the churches by appointing to the office of elder or bishop men who met the required qualifications (Titus 1:5-9). 
Paul outlined the qualifications for the office of an elder (bishop) (1 Tim 3:2-7). These requirements make it plain that the Lord, as Head of the church (Eph 5:30), is interested in having high spiritual and ethical standards, a record of successfully governing their own home, and a good reputation among unbelievers.

Werning (2003, p. 141) wrote that faith-full leaders develop mature faith that has character and a heart like God. Good leadership principles are vital, but it is faith that develops character and a heart like God to be productive in God's work. The mature faith of those placed in leadership is basic to growing a healthy, seed-planting church.

Schwarz (1996, p. 23) adds that leaders who realize their own empowerment by empowering others experience how the "all-by-itself" principle contributes to growth. Rather than handling the bulk of church responsibilities on their own, they invest the majority of their time in discipleship, delegation, and multiplication. Thus, the energy they expend can be multiplied indefinitely. This is how spiritual "self-organization" occurs. God's energy, not human effort and pressure, is released to set the church in motion.

The evangelistic strategy of the early church was powerful and very effective. The church literally exploded with growth. The various elements of the strategy-earnest prayer, relentless evangelism, church planting, holistic small groups, and spiritual leadership-all worked together as a harmonious whole. The heart of this strategy was the intentional planting of new churches.

Church planting is rooted theologically in the mission of God. The early disciples saw that mission modeled in the person and ministry of Jesus. Having received from 
Christ the commission to go and make disciples, they proceeded to raise new churches all over the Roman Empire.

Burrill $(1998$, p. 44) concludes that the planting of new churches is the object of all mission strategy. It should be the goal of every congregation to plant a new church. Only when a church planting priority is reestablished in the church, and as new churches are continually being planted in new groups of people, can we truly see the fantastic growth envisioned by the Great Commission.

\section{Ellen White on Church Planting}

To begin with, Ellen White (1962) points out that "God has a church upon the earth who is His chosen people, who keep His commandments" (p. 61). And, in addressing God's purpose for His church, White $(1911$, p. 9) explains that the church is the repository of the riches of the grace of Christ. It is the fortress, His city of refuge, which He holds in a revolted world. The church is God's appointed agency for the salvation of men. It was organized for service, and its mission is to carry the gospel to the world. From the beginning it has been God's plan that through His church shall be reflected to the world His fullness and His sufficiency.

Such is the divine duty entrusted to the church where each believer is to work hard to bring in souls; thereby multiplying the number of believers as well as congregations (churches) the world over.

With respect to the planting of new churches, White (1948) states that, "New territories are to be worked by men inspired by the Holy Spirit" (p. 24). She adds that, "Place after place are to be visited; churches raised up" (p. 20). She gives further 
explanation that those who are the chosen of God are required to multiply churches wherever they may be successful in bringing souls to the knowledge of the truth (p. 199).

Concerning the work of the early church, White (1983) states that, "The organization of the church at Jerusalem was to serve as a model for the organization of churches in every other place where messengers of truth should win converts to the gospel" (p. 91). Again, she points out that, "In the early history of the church when in various parts of the world many groups of believers had been formed into churches, the organization of the church was further perfected, so that order and harmonious action might be maintained" (p. 92).

As far as missionary work is concerned, White's emphasis almost always is on the need to enter new areas and to plant new churches. She (1946) writes:

Everywhere the light of truth is to shine forth, that hearts now in the sleep of ignorance may be awakened and converted. In all countries and cities the gospel is to be proclaimed. Churches are to be organized and plans laid for work to be done by the members of the newly organized churches. This gospel missionary work is to keep reaching out and annexing new territory, enlarging the cultivated portions of the vineyard. The circle is to extend until it belts the world. (p. 19)

White (1948) also notes the urgent need of the extension of the gospel work in foreign fields. She states:

There are places which are now a moral wilderness, and these are to become as the garden of the Lord. The waste places of the earth are to be cultivated, that they may bud and blossom as the rose. New territories are to be worked by men inspired by the Holy Spirit. New churches must be established, new congregations organized. At this time there should be representatives of present truth in every city and in the remote parts of the earth. The whole earth is to be illuminated with the glory of God's truth. The light is to shine to all lands and all peoples. (6:24)

White appeals to ministers of the gospel, and to all who believe in Christ, to get involved in the planting of new churches. To the ministers she writes that their labor should not be so much in the already existing, matured, and advanced churches but 
directed to the Savior. She (1948) states, "Place after place is to be visited; church after church is to be raised up. Those who take up their stand for the truth are to be organized into churches, and then the minister is to pass on to other equally important fields" $(6: 20)$.

White calls upon Christian believers to play their active part in the planting of new churches. She (1963, p. 315) writes that upon all who believe God has placed that burden of raising up churches, for the express purpose of educating men and women to use their entrusted capabilities for the benefit of the world, employing the means He has lent for His glory. She recognizes the fact that the planted congregations are memorials to God and are working agencies for the Master.

\section{Making the Strategy Culturally Appropriate to the Target Audiences}

The disciple-making purpose of Jesus was to be fulfilled among all nations. And if disciples were to be found among all nations, this meant that Christianity must not be localized in Judaism, but transformed to an international church. Burrill (1998, p. 35) observes that this internationalization of the church occurred very quickly in the experience of early Christianity. Within the lifetime of the original apostles Christianity had already ceased to be a Jewish sect and had become an international church that appealed across cultural lines.

This internationalization of the church could not have occurred had not Christianity become culturally relevant to the various nations. It is evidenced that the Jerusalem church seemed to favor a very Jewish form of church while the Antioch group pushed for diversity. If the church had insisted that the practice of Christianity conform to Jewish customs, Christ's mandate to make disciples among all nations would have been difficult to fulfill. 
The most striking example of the early church becoming culturally relevant to the groups that were evangelized is seen in the Jerusalem Council (Acts 15). The rapid expansion of Christianity beyond its Jewish roots, especially by the apostle Paul and his ministry to the Gentiles had resulted in the establishment of many Christian churches among people who had no Jewish background. Should Jewish customs be imposed on these Gentile believers? In other words, should the Gentiles first have to become Jewish in order to become Christians?

In order to answer this most basic question, the church had to define what Christianity was, in essence, and what was cultural in their expression of that Christianity. One of the hardest things for a church to do is to separate culture from essence. Acts 15 reveals that the early church was able to make that separation. As a result, disciples increased throughout the Roman world and Christianity ceased to be simply a Jewish sect, for soon the Gentile converts far outnumbered the Jewish converts.

Burrill (1998, p. 36) explains that Adventism, likewise, has experienced the internationalization of the church. Having originated in culturally conservative American New England, it was difficult for the church to conceive of an expression of Adventism different from theirs. Yet, as Adventism internationalized, the church in North America eventually lost control in various parts of the world. As Adventism became indigenous to local cultures and local leadership took over, the church grew much more rapidly than it had with North American control. The same phenomenon happened in Adventism that had happened in the early church. As a result, today non-North American Adventists outnumber North American Adventists nearly eleven to one. 
Only as the New Testament church allowed different cultural expressions of Christianity could it truly become an international church, making disciples of all nations. These different cultural expressions are absolutely necessary for the fulfillment of the Great Commission. Yet, in making Christianity culturally relevant, the church must not accept and follow fallen culture. The tendency of most Christians is to determine acceptability as defined by the dominant culture. Yet, biblically, the only determinant of right must be the word of God. Culture can only be affirmed or negated based on its conformity to the Bible.

In order to reach various cultures, it is needful for the church to package its message in the cultural baggage that will reach its targeted populations. Tippett (1970, p. 73) adds that there is the need to change the forms and techniques for presenting the Christian mission to suit our times.

Burrill (1998, p. 37) made further observation that many modern church growth writers have noted the necessity of culturally adapting the gospel presentation to the group the church is trying to reach. Much of this strategy has been built around the example of the apostle Paul:

For though I am free from all men, I have made myself a servant to all, that I might win the more; and to the Jews I became as a Jew, that I might win Jews; to those who are under the law, as under the law, that I might win those who are under the law; to those who are without the law (not being without the law toward God, but under law toward Christ), that I might win those who are without law; to the weak I became as weak, that I might win the weak. I have become all things to all men that I might by all means save some. Now this I do for the gospel's sake, that I may be partaker of it with you (1 Cor 9:19-23).

Clearly, Paul's strategy was to make the gospel culturally relevant to every group he attempted to reach. Paul did not compromise what he believed to be basic Christianity merely to reach people, but he definitely understood those parts that were culturally 
neutral and therefore adapted his presentation to meet the minds of people in the culture where they currently lived.

Regarding Paul's strategy, in order to keep that central message, Paul recognized that the form (not the content) had to change in order to get results. He noticed that he had to make changes as he went to different groups so that the gospel could get through to his hearers.

The end justifies the use of many diverse strategies, as long as it is not contrary to biblical principles. Paul was flexible in his communication for the sake of results. The nature of language requires Christians of all ages to do the same.

Zunkle (1989, p. 94) has the view that holding the balance between being culturally relevant and compromising the gospel will be difficult, but every church throughout history which God has led has been able to accomplish acculturation to the point that it compromises its theology, but if it fails to make its methodology culturally

relevant, it compromises the mission of the gospel. The key is to hold on to those strong biblical convictions while at the same time being culturally relevant to the group which the church is trying to reach.

\section{Summary}

Since the mandate of the Great Commission envisioned disciples among all people groups, it should not be surprising that the early church developed a deliberate strategy to plant culturally sensitive churches in every people group they found. The early church quickly developed into a church planting movement because this is what they imagined Jesus wanted when He gave them the Great Commission. They could not fulfill such a commission without becoming a church planting movement. Likewise, the 
Adventist Church today must once again become a church planting movement or it will cease to be a Great Commission church.

The church planting strategy of the early church is best illustrated by the apostle Paul in his church planting endeavors:

1. The church commissioned missionaries to plant churches. Acts 13:1-4; 15:39, 40.

2. The church planters contacted the audience they hoped to reach. Acts 13:14$16 ; 14: 1$.

3. The church planter then sought to communicate the gospel to receptive people. Acts 13:16-41.

4. They did not just present the gospel; the hearers were converted to Christ. Acts 13:48; 16:14, 15 .

5. New believers were congregated. Acts 13:43.

6. New believers were then established in the faith. Acts 14:21, 22; 15:41.

7. Leaders were appointed and consecrated in the new churches. Acts 14:23.

8. Leadership was fully transferred to the new leaders and the church planter left. Acts $14: 23 ; 16: 40$.

9. Paul continued a relationship with the churches he had founded. Acts 15:36; $18: 23$. 


\section{CHAPTER 3}

\section{LITERATURE REVIEW ON CHURCH PLANTING STRATEGIES}

\section{Introduction}

Burrill (2007) defines evangelism as, "the process of winning people to Jesus Christ and enabling them to be transformed by God into responsible church members who are ready to meet Jesus when He comes" (p.10). He views evangelism as the whole process of converting people. This process includes sowing, cultivating, and harvesting. Thus, the work of evangelism then does not end with baptism, but it continues until people are disciples and ready for the coming of Jesus. This project dissertation presents church planting as a means of sustaining these newly converted disciples and helping with their outreach. This review of church planting strategies comes in three segments: The first segment focuses on the literature regarding general church planting strategies. Literature in this section is both descriptive and evaluative of the manner in which Christianity gained a foothold within some selected regions in Africa.

The second section examines literature on critical contextualization, exploring the process of making the biblical text and its content meaningful and applicable to the thought patterns and situations of the followers of Islam in Northern Nigeria and the Atyap people of Zangon-Kataf in Southern Kaduna in particular. The literature review includes suggestions as to hów to facilitate cultural adjustments needed when engaged in cross-cultural evangelism. The third segment reviews literature on Muslim evangelism. It 
describes briefly the history and expansion of Islam in Northern Nigeria, identifying who they are, where they come from, and how they can be reached with the message of salvation.

\section{Growth of the Christian Church on the Continent of Africa}

Falk (1997, p. 23) states that Christianity was established in North Africa during the time of the apostles. It spread rapidly, won the allegiance of the majority of the population and contributed most significantly to the ministry of the Christian church during the first five centuries. Unfortunately, Islam virtually replaced Christianity throughout North Africa (except Egypt where it survived with much difficulty) when Islamic forces invaded the region during the seventh and eight centuries. Meanwhile, Africa, south of the Sahara, had only one main religion, African Traditional Religion (ATR).

Decret $(2009$, p. 19) states that the opening pages of North African Christianity seem to have no connection to the apostolic period. Nor is there a great episode of a golden legend, a great saint, or an apostle arriving on the African shores to convert the unbelievers. Rather, the history opens through the testimonies of blood; the martyr of twelve Christians: five women and seven men from the region of Scilli in Proconsularis (modern Tunisia) by the order of the governor's tribunal in Carthage on July 17, 180. The progress of Christianity in Africa was certainly challenged by imperial edicts. However, prior to any official opposition and, perhaps even afterwards, Christianity experienced opposition from other levels in African society. Deep religious feelings could be found at the heart of the pagan devout, and the masses had for some time been deeply influenced by mysticism. Because the Africans had always demonstrated a welcome attitude toward 
various religions coming from Rome, Greece, Egypt, Asia, and the East, they were intolerant of a new religion that made exclusive claims. In the same sense, the Africans had risen up against the deities throughout the provinces that had their own special cult or band of followers

Parrat (1997, p. 3), however, in his own version, believes that it was the Portuguese Catholics who first brought the Christian faith to Africa south of the Sahara, from the end of the fifteenth century. This early effort did not have much success. The beginning of the great thrust of Protestant missions into Africa came in the nineteenth century and had their origins in the Evangelical Awakening. The sub-Sahara Africans readily accepted the Christian faith. And, for further elaboration, Mbiti (1980, pp. 817820) explains that by 1900 there were an estimated nine million Christians, mainly in south-Sahara Africa. This figure accounted for seven percent of the population of Africa at that time. By 1980, there was an estimated two hundred million Christians or about forty-five percent of the population. He concluded by pointing out that in 2000 , the African Christian population had increased to three hundred and ninety-four million or forty-eight percent of the entire African population. Such has been the phenomenal growth of the Christian church on the continent of Africa south of the Sahara.

\section{The Advent Movement and Church Planting}

The Advent movement did not begin as a church planting movement. Knight (2009) states, "It must be confessed that the Seventh-day Adventist Church did not begin as a mission-oriented people; to the contrary, their earliest years found them as what we might call the anti-mission people" (p. 314). He substantiates this claim with historical 
documentation of the four developmental stages the church passed in its mission. $\mathrm{He}$ develops the four stages in the following:

It was discovered that between 1844 and 1850 , holding to the short-door theology, the church felt no burden to preach to any but those who had been in the Millerite Movement of the 1840s. "Shortsighted! We may say. Yes, but an essential stage in the development of Adventism. This Period of Adventist missions (1844-1850) freed up scarce resources from potential missions to build a doctrinal platform." The second stage of Adventist mission (1850-1874) restricted itself to North America. That was also a necessary step in the progression of Adventist mission. These years allowed for the development of a power base in North America that could eventually support a foreign missions project. We might think of a third stage (1874-1889) as mission to the Christians nations. Thus, Seventh-day Adventists sent their first official denominational missionary to Switzerland to call people out of Babylon. And even when they went to such places as Australia or Africa, the Adventists always began their work among the Christians of those nations. Limited as it was, the third stage functioned to establish additional power bases among the various Christian populations scattered around the world. As a result, those nations were prepared to act as home bases for the sending of Adventist missionaries at the beginning of the fourth stage of Adventist Missions, which began in 1890. We might regard that stage as mission to the world-not just Christian population around the earth, but to all people. (p.314)

The fourth stage of mission that the church entered into beginning in 1890 transitioned the Seventh-day Adventist church into a world-wide missionary church. Burrill (2007, p.51) observes that immediately after its official organization in 1863 with a little over 3,000 members, the Church grew at amazing speeds over the next few decades. The 1860s saw an annual growth rate of 7.9 percent. The rate skyrocketed in the next decade to the highest average in the history of the denomination, reaching an 18.6 percent growth rate per year throughout the $1870 \mathrm{~s}$. He notes that the nineteenth century was a time of rapid expansion of the Church. In raw numbers the Church grew from 3,000 in 1860 to 66,547 by 1900 . What caused this amazing growth is obviously, the swift development that came through starting new churches everywhere and the exploration of Adventism all over the world, as the Church began to grasp its missionary function. 
However, according to Alalade (2008, p. 314) there are still numerous areas throughout the world, particularly in the 10/40 window, where the Seventh-day Adventist Church has little to no presence. He observes that Northern Nigeria makes up the largest part of the country in both area and population. Yet, the Seventh-day Adventist work has made the least impact in it, partly due to the fact that it is predominantly a Muslim area. He notes that we did not know how to reach the Muslims in order to bring them to Christ. The places where we have a few churches are in the pagan areas where believers from the Southern and Eastern parts of the country have opened churches. The majority of the members have come to the church through medical and educational institutions. He further stresses that institutionalization of the church is one of the factors that limited the success of our missionary practice. Another limitation, he added, is the fact that we have to compete with Christians from other denominations that live in the so-called pagan areas.

Sahlin (2007, p. 43) argues that what is needed now is hundreds of lay groups in hundreds of local churches willing to launch out and experiment with new approaches to new people groups. He advocates that if the Adventist church does not allocate the resources of personnel, money, time, and attention that missions require, then it is not serious about the task of reaching every nation, tribe, language, and people group with the Three Angels' messages. The role of social concern and community in the mission of the church is no more clearly stated than in Ellen White's (1942) inspired passage on missionary strategy published in the Ministry of Healing:

Christ's method alone will give true success in reaching the people. The Savior mingled with men as one who desired their good. He showed His sympathy for them, ministered to their needs, and won their confidence, (p. 143) 
Today's churches are stagnating, shrinking, and dying. Unless our attention is drawn back to the Scriptures and we are able to see the importance of the work of the Great Commission, we may not experience a reawakening passion for church planting, a breaking heart for the lost, and a reshaping of our personal calling. As Gray (2007) puts it, "church planting is the most brutal ministry anyone can do" (p. 23). His observation in regards to church planting may be correct. However, we must not lose sight of the fact that it is rewarding, since it involves attempting something big for the Master. Of course, it may be frustrating and brutal because it tests every area of one's life, and there is an indisputable fact that church planters have to be dreamers, visionaries, and planners. Certainly, church planting gives a new sense of God's presence and convinces one that the enemy is alive and active. There is a celebration of the birth of a new church with joy, and there may be the experience of betrayal from friends and family in ways that one never thought possible. Throughout His ministry, Jesus exemplified the importance of evangelism. The Great Commission in Matt 28:19 is His call to the church to participate in the practice of evangelism. We can understand this to be a call to start new communities of believers by His disciples.

\section{Why Plant Churches?}

Gary $(2007$, pp. 31, 32) points out that the local church is the only hope for our world. The church is not a human invention, simply a man-made organization created to oppress and control the people of the world. It is a divine, God-ordained; Christcommissioned organism created to be an extension of the work of Jesus Christ. Its purpose is to offer salvation, wholeness, healing, and transformation to a sin-sick world. Jones (2004, p. 10) adds that any serious reader of the Bible will quickly see that God's 
nature is at the root of mission. The living God portrayed in the Bible is a sending God. He sends because of His love for the world. The church is called to be the living expression of the kingdom of God on this earth. It is to reach out to the lost with the truth and reality of the gospel. It is to form loving, nurturing communities of new believers. In so doing, the church, through the power of the Holy Spirit, should heal the spiritually sick.

A careful study of the Word reveals that the Great Commission is not a new calling to God's people. It goes back to the era of Genesis where God gave a very similar commission to Abraham: "Leave your country, your people and your father's household and go to the land I will show you. I will make you a great nation and I will bless you; I will make your name great, and you will be a blessing. I will bless those who bless you and whoever curses you I will curse; and all the peoples on earth will be blessed through you" (Gen 12:1-3).

This call to Abraham shows God's desire for Israel to become a movement that would touch the entire world, not merely a regional organization. God's desire was to bless "all the peoples on earth" through Abraham. God's design for the future of Abraham's role is one that was intended to transcend the socio-economic and ethnic borders of Israel. The church, like Israel, is not to become a stand-alone organization, but a life-giving organism that can influence the world. Malphurs (2000, p. 42) supports Gary's concept of church planting by observing that church planting is not new to denominational bodies. It is and always has been the "intentional pursuit of lost people" that naturally flows out of the Great Commission. As the church involves itself in this 
work, he states, "It is fulfilling the original call, given to Abram, to be a blessing to all the people on earth. Church planting is a fulfillment of that call" (p. 42).

Interestingly, Rohrmayer (2006, p. 5) gives inspiring reasons for church planting. He views church planting as the main vehicle for expressing God's mission; it is a key strategy in fulfilling Jesus' great commission. Rohrmayer recognizes church planting as the most effective means for making disciples and adds that it is necessary for the transformation of cultures and societies. He sees it as the most cost efficient means of evangelism; it is critical to establishing ongoing mission posts throughout the world. It is a natural by-product of a healthy church and is needed for the survival of the church. The planting of new, healthy churches is a means of seeing God's glory spread throughout the earth.

Sutter (2006, p. 18) supports Rohrmayer's views by professing a very important point for the urgency of church planting. He endeavors to convince us that we are still far away in fulfilling God's goal for the world. It is calculated that there are about 27,000 people groups in the world today. We have only reached about 14,000 with the gospel, but 13,000 people groups are still unreached. Surely we are contributing to the delay in Jesus' return.

\section{Strategies for Church Planting}

Dudley and Gruesbeck (1989, pp. 50-63) emphasize that if the Seventh-day Adventist Church takes the mandate of our Lord seriously to enter every community and people group on earth, plans must be laid now with guidelines and strategies for planting new congregations. Their point is that, if Adventists are serious about denominational 
growth, congregations should be encouraged to plant more churches wherever they are formed. They suggest five strategies for increased growth in the area of church planting.

\section{Strategy One-Educate for Awareness}

Two methods offer education for growth. One method is to develop a team of educators to conduct seminars in strategic locations throughout a union conference territory. The following areas of study are recommended for these seminars.

1. The importance of planting new congregations.

2. Where to plant a congregation.
A. Demonstrate how and where to collect demographic data
B. List what should be included in the study
C. Interpret the study.

3. The importance of finding resources (personnel, finances, equipment)
A. Match the resources with the felt need of the community
B. Discover those gifted toward outreach and those gifted toward nurture

4. The importance of planning
A. Identify the group to be reached
B. Identify the felt needs
C. Discover the programs which will meet the felt needs
D. Send the plan to the finance committee for approval
E. Send the plan to the church board
F. Present the plan to the church in a business meeting

5. Implement the plan or action

6. Evaluate the plan periodically 
The other method recommended to help people become aware of the need for church planting is to develop a model. This would involve finding a pastor or pastoral team to serve as a model for planting a church using the resources of the mother church. These model congregations would give other pastors and church leaders the opportunity to observe the performance of ministry in an infant church. It would give them ideas and insights to see first-hand the methods of success and the possible pitfalls to avoid.

\section{Strategy Two-Communicate the Progress of the New Congregation}

Since there is much evidence today that most people want to participate in the decision-making process, one of the best paths to effective action is to keep the constituency informed on the progress of new congregations and the exciting events taking place in new groups. Miracles and thrilling events resulting from people working under the direction of the Holy Spirit as they organize new churches need to be shared with fellow members.

\section{Strategy Three-New Congregations in the Cities}

- When people accept the gospel of Jesus Christ, they experience a natural desire to improve their status in life. Christians tend to become better educated and thus obtain higher paying jobs. They also want to raise the standard of living for their families and so they find a more comfortable home in a better part of the city.

In large cities without a congregation, leaders need to lay definite plans for reentering the cities and adding —even multiplying —new congregations. The idea of planting many more churches in the super-cities may seem overwhelming. The following are compelling reasons why we need to focus on large cities. 
1. The church can reach more people and grow faster by planting churches in cities. According to the New Church Analysis Study, a survey conducted by the Institute of Church Ministry Theological Seminary, Andrews University, Dudley and Gruesbeck (1989, pp. 53-54) report that fifty percent of the churches reporting negative growth were planted in towns or rural areas. In contrast, 64 percent of churches with an average growth rate of 40 percent or more were planted in medium-sized to urban areas.

Average attendance at the urban and suburban churches tends to be higher than the membership—a good sign of a healthy church body. Large attendance leads to overcrowding, influencing urban churches to begin new congregations.

2. A second reason for establishing urban churches is the counsel given the church that the cities must be worked. It is a mandate. E. G. White (1903) explains that she was moved by the Spirit of God to say to those in the Lord's work. "The favorable time for our message to be carried to the cities has passed by, and this work has not been done. I feel a heavy burden that we shall now redeem the time" (p. 31).

Many of these cities are in an area designated as a Standard Metropolitan Statistical Area, meaning that these cities are clustered together in main population centers. Churches within these clusters could be managed by a consulting group who would help them plan for the advancement of God's kingdom.

3. The third reason for evangelizing the cities is the example of Jesus Himself. Even though there were times when He worked with individuals in the thoroughfares of Palestine, as well as in some of the out-of-the-way places, He believed that His task was to warn the cities. In Jesus' day, the cities were the centers of education, commerce, and religion. He knew that if His message were to spread to all areas of Palestine, He needed 
to reach people in the great centers of influence. As He worked the cities, He sent out messengers to other areas of the country. Our own times are not different from His; today, the centers of influence are the cities.

4. Yet, there is a fourth reason for planting city churches. It is evidenced in Scripture that suggests that cities are the place to begin evangelism. One of the greatest church planters in Christian history was the apostle Paul. Paul's strategy was to evangelize the cities in Asia Minor, because he recognized them as centers of influence. They were the focal point of change. When the upper classes of the city accepted something new, it would filter down through the levels of society to reach the masses, as well as people living in the countryside.

Cities also have concentrated resources for gospel evangelism. How much easier to go from house-to-house in the city, where many people can be contacted in a short period of time rather than visiting folks in the countryside. The greater the population density, the more receptive the people. In large cities people are constantly moving from one place to another. People in movement are generally more receptive according to the New Church Analysis study.

\section{Strategy Four-Large Congregations Become Parents}

Another approach the church may take to reach out to millions is to encourage every church with over 400 members to plant a church every eighteen months to two years. Many members of large churches, however, have lost their vision and concern for lost people. They attend church as part of such a large group that they feel no need of extending their friendship to the unchurched. Ellen White (1948), in Testimonies to the Church (vol. 8), illustrates the problem of overcrowded congregations. 
Trees that are planted too thickly do not flourish. They are transplanted by the gardener that they may have room to grow and not become dwarfed and sickly. The same rule would work well for our large churches. Many of the members are dying spiritually for want of this very work. They are becoming sickly and inefficient. Transplanted, they would have room to grow strong and vigorous.

It is not the purpose of God that His people should colonize or settle together in large communities. The Disciples of Christ are His representatives upon the earth, and God designs that they shall be scattered all over the country, in the towns, cities, and villages, as lights amidst the darkness of the world. (p. 204)

A large mother church can readily take on the challenge of organizing a new congregation. Fifty members can easily leave without the congregation's really missing them. Another advantage of a large church becoming the parent of a new congregation is that talent from the mother church can enrich the program of the daughter churchprovided the new group does not lean too much on its parent's resources.

A third benefit of a church planting by a large congregation is the greater impact the new church has on the community, if 50 or more people become charter members. Some authorities suggest that the new church should have 100 or more charter members. New congregations generally grow faster when planted by a mother church.

Another church planting model for a large city centers on public evangelism. A city-wide evangelistic campaign concluding with 50-100 or more people accepting Christ provides an opportunity to plant a new congregation. Strong leaders who are willing to work with and accept the new converts are essential to the success of church planting activities. New believers can thus develop a loving, accepting, dynamic community of people who want to win their friends.

\section{Strategy Five-Planting by Transplanting}

A church planting model that is as old as the writings of Moses is the method God used when He invited Abram to leave his homeland and take his family to Canaan. This 
example could best be followed in heavily populated areas. The planting takes place by moving people into the area. Of course, caution must be exercised in making sure that appropriate jobs are available for people moving to the new area. If enough families move to the new area, a church school may be started.

White, in her book Evangelism (1946, p. 52) saw that close around us are cities and towns in which no efforts are made to save souls. "Why should not families who know the present truth settle in these cities and villages, to set up there the standard of Christ, working ... in God's way, to bring the light before those who have no knowledge of it?" (p. 52). She explains that brethren who wish to change their location should move into towns and villages where there is little or no light and where they can be of real service and bless others with their labor and experience.

Urging Adventists to move into the cities seems to be in opposition to the popular trend of most Christians, including Seventh-day Adventists. No one will argue against the advantages of suburban or country living. However, this church has been given counsel to move where the people are in order to win them for Christ. As Jesus mingled among the people of His day, we need to mingle among the city dwellers and tell them about a loving, caring Savior who wants to become the Lord of their lives. Today, many Christians are needed to move into the cities to win people to a saving knowledge and experience with Jesus Christ.

As Dudley and Gruesbeck (1989) put it, "God is willing to duplicate the experience of the apostles today and make it ours if we will only commit our lives to His leading. Plant a church. Reap a harvest. It is God's plan for church growth today" (p. 66). Rohrmayer (2006, p. 10) also emphasizes that church planting is at the heart of 
God's mission and we have the opportunity to be involved with it, and yet, if we are not careful, we can start churches that have all the appearance of being healthy, yet are not engaged in the mission of God.

\section{Universal Elements in Church Planting}

Moyer (2005 power point) presents ten universal elements in church planting strategy. These elements are global research and application. They are to be considered by any church planting movement.

1. Prayer--this is fundamental to every church planting movement. It is the first pillar in the master plan. The vitality of prayer in the missionary will be reflected in life of the new church.

2. Abundant Gospel Saving - this is the law of the harvest. When we sow abundantly we will reap abundantly. The church planting team may rely heavily on mass media, but never without personal evangelism.

3. Intentional Church Planting-churches do not just happen. Without intentional church planting all other forces are negated. Intentionality transforms evangelism into church planting movements.

4. Scriptural Authority-the Bible is the guiding source for doctrine and life. Scripture is the unquestioned rudder for church life.

5. Local Leadership-Missionaries should serve as mentors rather than the planters. Walking along side local church planters is first step in cultivating local leadership.

6. Lay Leadership - church planting movements are driven by lay leaders. The lay leadership should generally come from group being reached. For example, 
if group is illiterate, so is leader. Reliance on lay leadership ensures largest possible pool of potential church planters and cell church leaders.

7. Cell or House Churches-it is true that church buildings do appear, but the vast majority continue to be small, reproducible cell churches of 10-30 members.

8. Churches Planting Churches-the purpose of an apple tree is to produce more apple trees, not merely apples. Members must believe that reproduction is natural and no external aids are needed to start a new church.

9. Rapid Reproduction - this is essential to the church planting itself. When rapid reproduction rates slow down the movement falters. Rapid reproduction communicates the urgency of coming to faith in Jesus. It reduces distracting theological arguments.

10. Healthy Churches-there are five key indicators for healthy churches: Worship, evangelistic and missionary outreach, education and discipleship, ministry and fellowship.

When all these are present, the church cannot help but grow. The most important of these are enthusiastic, participating worship and missionary outreach. No church should be an "end" in itself.

\section{Obstacles to Church Planting}

Church planting is an act of God, but it is amazing how much mankind is capable of interfering with it. As with most of God's works among us, He allows us to actively cooperate with Him or become obstacles-consciously or unconsciously-to His desire, purposes. 
Garrison (2006, p. 49) observes that missionaries involved in church planting movements have identified several very human courses of action that tend to obstruct, slow, or otherwise hinder church planting efforts. He offers the most prominent obstacles to church planting facing the church today:

\section{Imposing Extra-biblical Requirements for Being a Church}

When a mission, conference, or union attempts to require a congregation to have extra-biblical things, such as land, a building, seminary-trained leadership, or paid clergy before granting them full status as a church, a church planting effort is obstructed. Christians may have the best of intentions when they impose preconditions before officially constituting a church; preconditions usually aimed at ensuring viability of the church before leaving it to its own devices. However, requirements, such as building, property, and salaried clergy can quickly become millstones around the neck of the church and make reproducing itself all the more unlikely.

\section{Loss of a Valued Cultural Identity}

Garrison (2006) believes that when a people have to abandon their valued ethnic identity and adopt an alien culture in order to become believers, the cause of church planting will not go far. Around the world, many churches that look culturally out of place in their setting serve as testimonies to this obstacle.

In too many instances, church planting has become cultural warfare, as missionaries and local Christians attempt to conquer and change the culture rather than allowing the Holy Spirit to transform the hearts of the people. Whenever one must become like a Russian, American, European, or any culture foreign to the people group 
being approach to become a Christian, there is little chance that the movement will spread rapidly among the new group.

\section{Overcoming Bad Examples of Christianity}

The spread of the gospel around the world has sometimes produced churches that are poor examples of the faith. If older churches in an area have non-regenerate members who engage in worldly and immoral behavior, it will be difficult for new believers to convince the lost that the Christian faith is holy and capable of redeeming the world.

\section{Non-reproducible Church Models}

It is an arguable fact that whenever missionaries begin planting churches with components that cannot be reproduced by the people themselves, they have undermined a church planting movement. Authentic church planting always takes on the appearance of their context. If villages are made of bamboo, then church buildings are made of bamboo. Church planting practitioners evaluate every aspect of each church start with the question, "Can this be reproduced by these believers?" If the answer is "no," then the foreign element is discarded.

\section{Subsidies Creating Dependency}

Money is not inherently evil. It has a vital role to play in the support of missionaries and promotion of things lost people or believers cannot do for themselves. Any time the gospel is introduced to a new people group, it may involve external support, but the problem is when outside funding creates dependency among new believers; this may stifle their initiative and therefore quench a church planting effort. 
Proper use of external funds include financing outreach to an unreached people, development of gospel literature, radio programming and broadcasts, production of films, Scripture translation, gospel television, cassettes, CDs, etc. When well-intentioned outsiders prop up growth by purchasing buildings or subsidizing pastors' salaries, they limit the capacity of the movement to reproduce it spontaneously and indigenously.

\section{Linear, Sequential Thought and Practice}

Garrison (2006) asserts that it is natural for missionaries to think in terms of sequential steps in church planting. For example, first you learn the language, then you develop relationships, then you share a witness, then you disciple believers, then you congregationalize, then you raise up leaders, then you begin another church start.

A non-linear approach which insists on the importance of witnessing from day one is preferred, even before the language is mastered. Rather than waiting for conversion, missionaries disciple the lost into conversion. By the time they have become believers; the new converts already have been participating in cell churches for some time and already have acquired a vision for starting churches.

\section{Planting "Frog" Rather than "Lizard" Churches}

A final obstacle offered by Garrison is metaphoric. Frog churches perceive themselves as ends in themselves, sitting fat and complacent on a hill or lily pad, expecting the lost to come to them in search of salvation, whereas lizards are always pursuing the lost. Adaptable and ready for action, they move quickly into the world through cracks and crevices, seeking the lost. Lizard churches penetrate the homes of the lost with evangelistic Bible studies rather than requiring the lost to come to their churches. 


\section{Critical Contextualization}

\section{Contextualization Defined}

Every missionary confronts the difficulty of cross-cultural communication.

However, missionaries from developing countries, Nicholls (2006) says, must understand four cultures-“The Bible; the Western missionaries, who first brought the gospel, their own, and the people's to whom they take the gospel."

Recognizing this, Nicholls (2006) proposes that the gospel be contextualized, that is "presented in forms which are characteristic of the culture to which the gospel is taken" (p. 45). Yet, the problem with this definition is to find the right cultural forms and thus keep the gospel message both clear and biblical. Moreau (2005, p. 335) argues that the definitions of contextualization differ depending on the emphasis placed upon Scripture and the cultural setting. Models emphasizing Scripture, he explains, usually define contextualization as the translation of biblical meanings into contemporary cultural contexts. Therefore, images, metaphors, rituals, and words that are current in the culture are used to make the message both understandable and impactful.

According to Hesselgrave (1995),

Acceptable contextualization is a direct result of ascertaining the meaning of the biblical text, consciously submitting to its authority, and applying or appropriating that meaning to a given situation. The results of this process may vary in form and intensity, but they will always remain within the scope of meaning prescribed by the biblical text. (pp. 115-20)

It is purported that contextualization is derived from the dynamic relationship between gospel and culture, between cultural relevancy and theological coherence. It is an effort of formulating, presenting, and practicing the Christian faith in such a way that it is relevant to the cultural context of the target group in terms of conceptualization, 
expression and application; yet maintaining theological coherence, biblical integrity, and theoretical consistency.

Contextualization can be understood to be an attempt to communicate the message of the person, works, Word, and will of God in a way that is faithful to God's revelation, especially as put forth in the teaching of Holy Scripture, and that is meaningful to respondents in their respective cultural and existential contexts. In other words, what they attempt to pass across to us is that appropriate contextualization focuses on authentic understandings or faithfulness to Scripture. Contextualization thus involves conceptions of revelation (God's communication of eternal truth in human linguistic and cultural categories); interpretation ("The readers' or hearers' perception of the intended meaning"); and applications of his understanding of the biblical text and how he "decides to accept the validity of the text's implications" by totally accepting it, accepting some parts and rejecting others, or superimposing his own meaning upon the text (p. 203).

White (1891) adds that human wisdom, familiarity with the language of different nations, is a help in the missionary work. An understanding of the customs of the people of the location and a time of events, is practical knowledge; for it aids in making the figures of the Bible clear, in bringing out the force of Christ's teaching to way-faring man may find the pathway cast up for the ransomed to walk in and there will be no excuse found for anyone who cherishes through misinterpretation of the Scriptures (Adventist Review and Sabbath Herald, Dec. 21). "The minister must not feel that the whole truth is to be spoken to unbelievers on any and every occasion. He should study carefully when to speak, what to say, and what to leave unsaid. This is not practicing deception; it is working as Paul worked" (Gospel Workers, p. 117). 
White (1962) cautions that the people in every country have their own peculiar, distinctive characteristics, "and it is necessary that men should be wise in order that they may know how to adapt themselves to the peculiar ideas of the people, and so introduce the truth they may do them good; they must be able to understand and meet their wants" (Testimonies to Ministers, p. 213).

\section{Syncretism}

Syncretism cannot be defined without an understanding of contextualization, since the two processes are interrelated. As has been illustrated by some other authors, what is considered authentic contextualization by some may be interpreted as syncretism by others? Kato (1975) states, "The New Testament has given us the pattern for cultural adaptation. The incarnation itself is a form of contextualization. The Son of God condescended to pitch his tent among us to make it possible for us to be redeemed" (p. 1217). This definition established the need for contextualization and illustrates that an overemphasis upon the cultural context can lead to syncretism.

Van Rheenen (2006, p. 173) adds that syncretism occurs when Christian leaders accommodate, either consciously or unconsciously, to the prevailing plausibility structures or worldviews of their culture. Syncretism then, "Is the conscious or unconscious reshaping of Christian plausibility structures, beliefs, and practices through cultural accommodation so that they reflect those of the dominant culture" (p. 173). Or, we may understand it in other simpler terms as the blending of Christian beliefs and practices with those of the dominant culture, so that Christianity loses its distinctiveness and speaks with a voice reflective of its culture rather than a biblical foundation. . Syncretism is birthed out of a desire to make the gospel relevant. The Christian 
community attempts to make its message and life attractive and appealing to those outside the fellowship. It occurs when Christianity opts into the major cultural assumptions of a society.

Missiologists' writings tend to focus on contextualization with only brief notations about syncretism. There are many reasons for this. Writing about contextualization, the message of the gospel in the life of the church is much more appealing than discussing excessive accommodations to the philosophies and practices of the dominant cultures. Truly, we also live in an age of tolerance. Few are willing to negatively critique the beliefs and practices of others. Missionaries and Christian evangelists should therefore consider both points of contact and points of contrast. The accommodations of today can become the syncretism of tomorrow. This brings us to the concept of critical contextualization.

\section{Critical Contextualization}

The question that comes to mind is, what should people do with their past customs when they become Christians? Must all of a people's past culture change when they become Christians? If not, what must change and who should make the decisions? How should a missionary or church leader respond to traditional rituals and other cultural customs? Hiebert suggests three possible responses to the former practices of a given people: reject, accept, or confront.

\section{Reject the Old}

One common response has been to reject all old customs as pagan. Hiebert (1987, pp. 104-112) has the view that this wholesale rejection of old customs creates several serious theological and missiological problems. First, it is based on the implicit 
assumption that the cultural forms of Western Christians are themselves Christian. An uncritical rejection of other cultures as pagan is generally tied to an uncritical acceptance of our own cultural expressions as biblical.

A second problem is that new customs must be found to replace the old ones that have been rejected. Too often the missionary imports customs from his or her own culture, unaware that these will be reinterpreted and often misunderstood within the local culture.

The importation of cultural practices from outside has made Christianity a foreign religion in many lands, and alienated Christians from their own peoples and cultures. It is these foreigners and not the offense of the gospel that has often kept people from following Christ. Care must be taken so that we do not confuse the two.

In the third place, attempts to suppress old customs generally fail. Pauw (1975, p. 208) points out that many missionaries have come to realize that an attempt to eradicate an undesirable custom may merely drive it underground or result in an undesirable reactionary behavior. There the old customs are perpetuated out of sight of the leaders. Too often the leaders end up as "policemen" trying to enforce the rules they have made. Hiebert also argues that when decisions to reject old customs and to replace them with new ones are made by the missionary or pastor, the church as a body does not mature. The Christians remain spiritual children who learn compliance, not personal discipleship. A strong church is based upon the priesthood of all believers, and all members must be taught to discern right and wrong in their own lives, and to encourage one another in leaving old ways they have corporately rejected, and to check the errors of the leaders. 


\section{Accept the Old}

A second response to traditional practices has been to accept them uncritically into the church. The old cultural ways are seen as basically good and few if any changes are thought to be necessary when people become Christians. Those who advocate this approach, generally have a deep respect for other peoples and cultures, and recognize the high value people place on their own cultural heritage. They also recognize that the foreignness of the gospel has been one of the major barriers to its acceptance. Consequently, they stress the communication of the gospel in indigenous forms and call for little or no cultural dislocation.

This approach, too, has serious weaknesses. A tendency exists to overlook the fact that these are corporate and cultural sins as well as personal ones. It may not be wise to equate indigenization with an uncritical acceptance of a culture. Clearly the gospel calls both individuals and societies to change. Indigenization is communicating the gospel in ways the people understand, but in ways that challenge them in their personal and corporate lives with God's call to discipleship.

\section{Deal with the Old}

A third approach to past customs is to confront them consciously in a process Hiebert calls critical contextualization. In this process, the old is neither rejected nor accepted uncritically. It is explicitly examined with regard to its meanings and functions in the society, and then evaluated in the light of biblical norms. How does this occur? First, the church becomes aware of the need to recognize some area of its life. This awareness may arise as people are faced with specific occasions. Or, someone may sensitize the church to practices that need to be examined. This discernment of areas of 
Christian life that need biblical critique is one of the important functions of the leaders in the church. Failure to acknowledge the culture in which the church finds itself often allows sub-Christian practices to enter the Christian community unnoticed.

Second, the missionary or pastor leads the congregation in the gathering and analysis of the various practices that make up the custom under examination. The purpose here is to understand the old ways with empathy. Consequently, the leaders must remain nonjudgmental, for the rush to judgment at this point is to close the door on the custom.

Third, the pastor or missionary should lead the church in a Bible study related to the question at hand. This draws upon what the leaders have most to contribute, namely their knowledge of the Bible. It is important that the people clearly understand and accept the biblical teaching, for failure here leads to an incomplete processing on their part of their cultural past. Obviously, as members of the congregation grow in spiritual maturity, they, too, should be encouraged to take an active part in studying and interpreting the Scriptures.

\section{Summary}

In summary, Hiebert (1987, pp. 104-112) suggests a number of ways a congregation might respond to old beliefs and customs:

\section{Keep that which is Not Unbiblical}

Many cultural practices are neither Christian nor non-Christian. They are neither sanctioned nor condemned in the Bible, and therefore Christians can be ambivalent about them. Hanging certain kinds of art in the church building might be an example. In keeping such practices the church can reaffirm its own cultural identity and heritage. 


\section{Reject that which is Unbecoming for Christians}

Sometimes we might be surprised by what is rejected because we don't understand the significance of the rejection of certain songs, customs, beliefs, and so forth. On other occasions to help the congregation remain aware of any cultural blind spots, the evangelist will need to probe why certain customs have not been rejected.

\section{Modify Practices to Give Them Explicitly Christian Meaning}

Hiebert mentions Charles Wesley's use of popular pub songs to which he set Christian lyrics and the fact that the early Christians used the synagogue form of worship, but modified it to fit their beliefs. In our context, if we were trying to reach young people, we might reject "moshing" as an aggressive form of dancing that emphasizes individuality. ... Or we might validate it, but modify it to express togetherness, community, and vitality.

\section{Reject Current Unbiblical Practices and Replace Them}

People who are living together when they become Christians would be encouraged either to get married or to live separately. The close relationship is not rejected; it is simply replaced with a structure that is more in keeping with Christian morality.

\section{Adopt Rites Drawn from Christian Heritage}

Naturally the adoption of the Lord's Supper and baptism connects any congregation with their new history as Christians. Culturally sensitive expressions of the communion feast and the rite of entry through baptism need to be thoroughly and biblically contextualized by the church. 


\section{Create New Symbols and Rituals}

Finally, develop new, fresh expressions of the Christian experience. The Jesus Movement of the late 1960s and early 1970s - forms of which experienced a revival in the 1990 s — developed a series of hand signals, sayings, slogans, and even jewelry to communicate Christian beliefs.

Faithfulness to the Great Commission demands that Christians, churches, and denominations faithfully proclaim the gospel in a way that both communicates to the world around us and remains faithful to biblical gospel. Let us commit to do all we can to bring the good news of Jesus Christ to a lost world. That includes the hard work of critical contextualization.

\section{Reaching the Muslims}

\section{Brief Islamic History}

Hakim $(2009$, p. 1) writes in his article "Religion of Islam" that the word Islam means "submission to God." The Holy Quran describes Islam as an Arabic word deen (way of life). The followers of Islam are called Muslims. The literal meaning of Muslim is "one who surrenders" or "submits" to the will of God. In order to understand Islam, the basic portrayal of belief in Quran must be considered. According to the Quran, those who submit to God are Muslims. The Quran also declares that all the prophets who came before Mohammed and their followers were Muslims. Hakim adds that it was the birth of the prophet Mohammed in 570 A.D. in the city of Makkah which brought a revolution to the entire fate of the nomadic Arabs. He became famous among the people of Makkah at a very early age because of his allegiance and reliability. He was widely known as Al-Ameen (honest, trustworthy). 
Hakim further reveals that Mohammed started proclaiming the message of believing in one God. The people who once called him "trustworthy" and "honest" boycotted and plotted to kill him. In 622 A.D., due to worsening living conditions and social isolation, the prophet Mohammed migrated to Medina along with his followers. This flight was known as "Hijirah" and marks the beginning of the Muslim calendar. Mohammed's message spread rapidly and the numbers of followers increased in Medina. During the next few years, a series of battles were fought between various tribes of Makkah and the Muslims of Medina. Mohammed died in 632, A.D. at the age of 63 in the city of Medina. His death brought a huge catastrophe among Muslims.

Sahib (2009) writes in his article "The condition of Arabs before the advent of the holy Prophet and the transformation he wrought in them," that it was from such debating idolatry, the holy prophet uplifted the whole of Arabia in a brief span of twenty years. He sees this as the mightiest miracle that the world has witnessed.

\section{Terminology}

Allah - The Supreme Being. The name of God.

Hadith - The sacred sayings of Muhammad, handed down by oral tradition and finally written down.

Hajj-Pilgrimage to Mecca. One of the five pillars of the Islamic faith.

Hijrah - Muhammad's flight from Mecca to Medina in 622 A.D.

Islam - "submission to the will of Allah."

Koran (Qur'an) - The inspired word of God given to Muhammad by the angel Gabriel.

Makkah - The birthplace of Muhammad, and the holy city of Islam. 
Medina - Holy city named for Muhammad after he fled there in 622 A.D.

Muhammad - Prophet and founder of Islam. Born around 570 A.D., died 632

A.D.

Muslim - Follower of Muhammad. It literally means one who submits to the will of Allah.

Mosque - Islamic place of worship.

Muezzin - Muslim caller who announces the hour of prayer.

Peace Be Upon Him - An expression used by Muslims to show respect and reverence to all prophets of Allah. Muslims usually say it just after mentioning the name of Prophets.

Ramadan - The ninth and one of the most sacred months of the Muslim year. It is the month in which Holy Quran was revealed to Prophet Muhammad. It is now considered as a month of fasting.

Salat - Muslim daily prayer ritual. One of the five pillars of Islam.

Shi'ites - Muslim sect which insists that Muhammad's son-in-law 'Ali was Muhammad's rightful successor.

Sufi-A Muslim mystic and/or ascetic.

Sunnites - Largest Muslim sect which acknowledges all of Muhammad's successors.

Surahs - What the chapters of the Qu'ran are called.

Islam in Northern Nigeria

Islam came to Northern Nigeria as early as the ninth century C.E., and was well established in the Kanem-Bornu Empire during the reign of Humme Jilmi. It had spread 
to the major cities of the northern part of the country by the sixteenth century, later moving into the countryside and towards the Middle Belt uplands. Islam was first documented in the ninth century. Religious archives showed Islam had been adopted as the religion of the majority of the leading figures in the Bornu Empire during the reign of Mai (king) Idris Alooma (1571-1603). He furthered the cause of Islam in the country by introducing Islamic courts, establishing mosques, and setting up a hostel in Mecca, the Islamic pilgrimage destination for Kanuris.

The Encyclopaedia Britannica (2007) documents that in the early 1800s; Islamic scholar Usmandan Fodio launched a jihad, the Fulani War, against the Hausa Kingdoms of Northern Nigeria. He was victorious and established the Fulani Empire with its capital at Sokoto. The vast majority of the Muslims in Northern Nigeria follow Sunni Islam. However, there is an insignificant Shia minority primarily in Sokoto. A relatively smaller minority follow the Ahmadiyya Islam, a reformatory sect originating in nineteenth century India.

\section{Main Islamic Beliefs}

Shelley and Audrey (2009) note that the teachings of Quran and Hadith (sayings of the prophet Muhammad) revolve around two Arabic words, namely emaan (faith) and amaal (acts). Emaan is like the roots of a tree, and amaal are the stems, leaves, or other parts of it. Just as without the roots, the tree cannot survive, similarly, without faith, the acts are useless. The teachings of the Quran emphasize mostly the beliefs and overview the acts, whereas the Hadith explains both beliefs and acts in detail. Muslims believe that, although there may be reservations in the Hadith, the Quran is free from all the mistakes and is infallible. 


\section{Six Articles of Faith}

Hakim (2009) shows that there are six articles, and these are the main doctrines of Islam. Thus, all Muslims share beliefs in the following:

1. God - Islam preaches that there is only one Supreme, Eternal, Infinite and Unparalleled entity, Allah (6:102).

2. Angels - Muslims believe in the existence of angels. They are comprised of light, and each has different purposes. The angel Gabriel brought the divine message to Muhammad.

3. Scriptures -What the Muslims refer to as Scriptures are the Torah (Moses), the Psalms (David), the Gospels (Jesus), and the Qur'an (Muhammad). They also believe that all other books have been altered with time by its followers. However, the Qur'an is the only book which can never be distorted (15:9).

4. Prophets - It is obligatory for every Muslim to believe in all the messengers from Adam to Muhammad without any discrimination. They believe the Qur'an treats all the prophets equally $(2: 136)$.

5. Resurrection - Muslims have the faith that at the end of the world, every human being will be resurrected from the grave. They will be held accountable for whatever they have done in their lives $(36: 65)$.

6. Divine Creed - It is one of the main aspects of Islamic beliefs. Believing in divine creed refers to predestination. Muslims believe that, unlike living beings, God is not limited to anything, even with time. 
The Five Pillars of Faith

The five pillars of faith are duties each Muslim performs to demonstrate his or her faith. They are as follows:

1. Testimony of Faith (kalima) - One must state, "There is no god but Allah, and Muhammad is the Prophet of Allah."

2. Prayer (salat) - It is compulsory for every Muslim to pray five times a day at respective timings, facing towards the direction of Mecca. During the prayer, Muslims narrate verses from the Holy Quran.

3. Almsgiving (zakat) - The word zakat means "to grow" or "to purify." It literally means to gain Allah's blessings and purify the wealth by helping the needy. It is mandatory on every Muslim to give five 2.5 percent of their yearly savings (9:16).

4. Fasting (sawm) - Following zakat, every Muslim is required to fast during the month of Ramadan from sunrise to sunset.

5. Pilgrimage (hajj) - Hajj literally means to "set out for a place." For Muslims, it is a pilgrimage to Kaaba (House of Allah) in Makkah. It is the responsibility of every physically and financially able Muslim to perform this offering at least once in a lifetime.

\section{Resistance to Christianity}

Jeschke (2010) observes that Islam has derived a very basic doctrine, namely, that although Jesus and Christians have received revelations from God, they have not preserved these faithfully. As a result, God had to issue this revelation through Muhammad and the Quran. He explains that, even though Jews and Christians are tolerated in Muslim societies as people of the book according to Islam their faiths are corrupted versions of the faith that God has corrected in Islam. God has granted 
numerous revelations through Moses and the Torah, through David and the Psalter, and through Jesus and the evangel. However, these always got corrupted, so the final and definitive revelation was given through Muhammad in the Qur'an. This one, Muslims hold, has not been corrupted but has been faithfully preserved these nearly 1,400 years.

Given this basic understanding in Islamic thought, the overwhelming majority of Muslims see Christianity the way most Christians through most of Christian history have been Judaism as a religion that has been superseded. Most Christians have thought that, since Jesus is the fulfillment and correction of Judaism, Jews should have believed in Jesus as Messiah and become Christians. Judaism should have disappeared. This explains Muslims' notorious resistance to conversion to Christianity. As most Christians do not find any appeal in an invitation to convert to Judaism, because it seems like a step backward historically and religiously, so Muslims are repulsed by any invitation to convert to Christianity.

Jeschke (2010) adds that, whereas Christianity sees itself as the fulfillment of the Jewish faith and hope and therefore retains the Hebrew Scripture, the Old Testament, as canonical Scripture, Islam does not see the Christian Bible as canonical, and therefore Muslims do not study it with the exception of some scholars, mainly those with some influence from Western education. As a consequence, most Muslims never encounter those powerful stories of Jesus in the gospels. If they do, they are still inclined to take only what the Qur'an says about Jesus as ultimately trustworthy. 


\title{
Muslim Evangelism
}

\author{
Creating Friendship
}

Genuine friendship is the most important condition for establishing a good and amiable relationship with a Muslim. First, there must be some personal contacts. It is of utmost importance that mutual confidence and understanding is brought about as a valid foundation for meaningful communication. Muslims have the same joys and sorrows, burdens, fears, hopes, and failures as other people. They have weaknesses to overcome in the same way as Christians do.

From my personal experience with Muslims, having served among them for over thirty years in Northern Nigeria, they highly regard an appreciation expressed for a favor or a courtesy, a friendly word for a service. They appreciate a helping hand and an apology when the situation requires it. These are steps in the direction of meaningful friendships that will help in integration and in the playing down of unpleasant cultural clashes.

From my personal observation, another important factor in making friends and gaining respect is the need to have an elementary knowledge of the religion of Islam, its belief system, rituals, rules, and regulations. In developing an effective friendship with a Muslim, hospitality is paramount. Schantz (2003) states, "Hospitality is, without doubt, the surest way to a Muslim's heart" (p. 142). Hospitality is an important part of the Islamic culture. It is a positive virtue. Taber $(2004$, p. 91$)$ also supports the idea of giving hospitality. In considering the writing of the apostle Paul states "Do not forget to entertain strangers for by so doing some have unwittingly entertained angels" (Hebrews $13: 2)$. 
Taber (2004) points out the significance of listening to your Muslim contact. In most cases, your contact is willing and prepared to talk about his or her religion. It is, perhaps, not recommended that we engage in discussion on doctrines in which Christians and Muslims differ until a mutual relationship of trust has been established. One also has to be an honest listener. When the Muslim mentions faults and mistakes in the way Christianity is practiced, one should not try to defend the indefensible. Honestly admit it when he or she is right or has a valid point.

In order to get into the heart of a Muslim personal conversations are more important than group discussions. Invitations to attend church or Christian meetings should not take place before a natural and relaxed friendship has been established. With their strong ties of solidarity, Muslims will not only observe the doings of one another, but will also monitor non-Muslim activities, attitudes, and friends. They will always be under group pressure from concerned fellow Muslims.

We must appreciate the fact that in all conversations, it should be remembered that Islam is not only a religion with beliefs and rituals; it is the guide to their whole existence. The Muslim is not just a part of his family; he or she is part of the Islamic nation, as well as the worldwide community. The witness of the Christian faith could convince a Muslim, but it is still extremely difficult and could prove fatal to change his religion.

In addition, Schantz (2003) and Taber (2004) continue to argue that it is imperative that any persuasive dialogue, preferably conducted in private, will accomplish most and protect the Muslim interested in Christianity from pressure from both the family 
and the group. However, I think sometimes it is advisable, whenever possible, that dominant members of the family know what is going on.

It should be noted that criticism be avoided in a conversation with a Muslim. A conversation with a Muslim can easily develop into a discussion of the relative advantages in Christianity compared with Islam, Christ with Muhammad, the Bible with the Qur'an. Generally, such debates are futile. Although dialogues on sensitive issues in the long run cannot be avoided, however, a direct confrontation should not take place until a solid platform of mutual trust with respect, tolerance, and indulgence has been built. Such discussion should take place in a spirit of objective honesty and reliability.

\section{Contextualizing for Muslims}

In this chapter we have analyzed contextualization. We have seen the need for an appropriate contextualization so that it does not lead to syncretism. Again, Martin (2008, p. 18) defines contextualization as the process of making the biblical text and its context meaningful and applicable to the thought patterns and situations of a given people. It covers the cultural adjustments that have to be made in cross-cultural evangelism. Martin sees syncretism as just the fusion of two beliefs. Frequently, syncretism is born of a desire to make the gospel relevant. This subheading on reaching the Muslim with the gospel deals with the methods the church should contextualize for Muslims.

For those of us who minister to Muslims, certain questions keep reoccurring. How much does one have to understand and believe to be a Christian? What must a convert include about Muhammad? Can a convert retain some forms of Islamic worship, and when should a convert be baptized? We are faced with practical problems that need consideration. For example, in the North-east Nigeria Conference when new converts 
from Islam come to the church, we are faced with the problem of rehabilitation. Who will befriend the convert and where can he/she find work? Converts are often doomed to a life of loneliness and isolation. There is the need to be culturally sensitive, yet remain faithful to the truth. Contextualization must strive to accommodate, but without compromise.

Whitehouse (as cited in Martin, 2006, p. 123) admits that the advocates of "Faith Development in Context" (FDIC) ministries forge their theology according to the situational realities in the Muslim world. Martin summarizes the "Contextualization Spectrum." The "C-Scale" measures the level of contextualization from one through six among "Christ-centered communities" found in the Muslim context. However, the question is, How far can we go up in this scale without compromising the integrity of the gospel? The point of contention is concerning the validity of a C-5 approach as it is currently used by FDIC missionaries.

C-1 Traditional church using outside language. These terms are used with conversing with converts who have been rooted from their culture.

C-2 Traditional church using inside language. These terms are used when conversing with converts who are able to transcend cultural differences and can worship using foreign worship patterns.

C-3 Churches using inside language and religiously neutral inside cultural forms. This approach is used with converts who feel at home in worship since they are linguistically and religiously neutral, native cultural forms. 
C-4 Contextualized Christian-centered communities using inside language and biblically permissible cultural and Islamic forms. This approach is for people comfortable with the combination.

C-5 Muslim communities that affirm they are followers of Isa the Messiah. They still live legally and religiously within the community of Islam. The terms used are strictly confined to followers of Islam who believe in Jesus as the elder brother and the Messiah, but have not rejected Islam.

C-6 Secret/underground believers that are believed to be Muslims by the Muslim community and saying themselves that they are Muslims. The terms used in public are familiar to followers of Islam, but the terms used in private, among followers of Christ, will reflect a Christian world view.

Another adaptation of the C-Scale, as explained by Martin, can be used to describe different levels of willingness to adapt in the missionary's mindset. This second describes the C-Scale from the perspective of the outsider, that is, the missionary.

C-1 Missionaries make no attempt at contextualization at all.

C-2 Missionaries offer a Western church using inside language.

C-3 Missionaries show appreciation for the local culture by incorporating into worship as many neutral inside cultural forms as possible, such as music, artwork, and ethnic dress.

C-4 Missionaries create contextualized Christ-centered communities that not only use local language and incorporate neutral cultural forms in worship, but also biblically permissible Islamic forms, such as praying with arms rose, touching the forehead on the ground while praying, and separating men from women. 
C-5 Missionaries believe that a Muslim can be saved without leaving Islam.

Some baptize Muslims who are not even aware that they are joining the body of Christ. Some missionaries go so far as to legally become a Muslim by repeating the Shehadah in front of witnesses.

C-6 Secret/underground believers who are believed to be Muslims by the Muslim community and who themselves say that they are Muslims.

Martin agrees that missionaries with a C-5 mindset have developed a theology that proposes that God created all religions in which there are kernels of truth. As the result of a subsequent apostasy, however, a remnant must be raised to restore the truth (just as happened with Christianity). The implication is that, following the Muslim pattern, a Hindu, for example, could be baptized without leaving Hinduism, and a secular person could be saved in the remnant that God is calling out in the secular community.

This concept is based on an assumption for which there is no solid biblical support. The remnant concept of the C-5 approach is a radical departure from the historical Adventist understanding of the remnant as a body of believers who have "come out" of their religious communities (Rev 14:6-12;18:1-4) and have identified with a separate and visible group of people who have determined to be loyal to God (Rev $12: 17)$.

Martin's understanding that a missionary with a C-5 mindset reduces the church to what Islam can reasonably tolerate is a possibility. This could result to an erosion of Christianity and an open form of syncretism. However, I am also of the opinion that missionaries should be careful not to put obstacles for the salvation of souls that Christ died for. 


\section{Prayer}

Burrill (2007, p. 129) stresses the importance of prayer in every human endeavor. This is because prayer unleashes the power of heaven in one's ministry and God is also to do more to reach people, irrespective of their religious affiliation, when His people pray. Prayer is power, and prayer less efforts is powerless efforts. People are reached not by human persuasion and logic, but by the awesome power of a prayer-yearning God. Rankin (2006, pp. 57-65) also points out that our basic means of understanding and fulfilling God's mission is prayer. An amazing promise is given to us in Psalm 2:8: "Ask of me and I will surely give the nations as your inheritance and the very ends of the earth as your possession."

The fact remains that we need to pray for non-Christian people. We need to fervently pray for the unreached people groups of all nations. Without the fervent prayers of Christian believers, generation after generation continues in the bondage of darkness and sin. God yearns to draw them into His kingdom. Satan is clever enough to get us to limit our praying to personal matters-our personal needs and concerns, our families, our communities, and our churches. It is imperative that Christians intercede for the nations. Lucifer's strongholds remain secure against the kingdom of God when we never pray for the unreached people groups. Prayer is not just a peripheral mission strategy; it is the heart of our strategy to reach the nations and fulfill the Great Commission.

In an effort to reach Muslims with the message, Strong and Page (2006, p. 316) give emphasis on the importance of prayer. Prayer, lots of prayer, must precede any meaningful effort in Muslim evangelism. Prayer will continue to inform and guide the 
decisions of those who make themselves available to God as channels. Strong and Page add that the workers who have been successful in reaching Muslims have to set prayer times together daily in addition to their personal devotional times. By clearly and openly acknowledging through prayer their dependence on God alone in all things, they declare themselves as His willing, obedient servants and direct praise to the Lord and not to themselves or their success.

White (1958, p. 370) continues to support the concept of prayer. She admonishes us not to be careless in regard to the need for prayer for the unreached people. "Let no one who believes the truth be silent now. Let all urge their petitions at the throne of grace, pleading the promise, 'Whatsoever ye shall ask in my name, that will I do' (John 14:13). Let our united cries be sent up to heaven. Pray and work, and work and pray" ( $p$. 370). She adds that we must pray and work and believe. We are to trust in the Lord because $\mathrm{He}$ is our efficiency (Evangelism, p. 438).

White (1956, p. 94) again gives emphasis on the essence of prayer for success in any meaningful effort. She encourages us to learn from our Savior. If Christ, the Son of God, felt the need of prayer, how much more should feeble, sinful mortals feel the necessity of fervent, constant prayer? "The darkness of the evil one encloses those who neglect to pray. Why should the sons and daughters of God be reluctant to pray, when prayer is the key in the hand of faith to unlock heaven's storehouse, where are treasured the boundless resources of Omnipotence?" (SC 94).

In an effort to reach the Muslims with the gospel, wisdom is needed. This is not the wisdom that the world gives, but wisdom that comes from God. In her further comments, White (1962) assures us that the Lord has given us the promise that if we lack 
wisdom, we should ask of Him that gives to all men liberally. "It is in the order of God that those who bear responsibilities should often meet together to counsel with one another and to pray earnestly for the wisdom which He alone can impart" (TM, p. 499).

\section{Summary}

This chapter has attempted to present the fact that the church is not a human invention or a man-made organization created to oppress and control the people of the world. Rather, it is a divine, God-ordained, Christ-commissioned organism created to be an extension of the work of Jesus Christ. The reason for the establishment of the church is to offer salvation, wholeness, healing, and transformation to a sin-sick world. It is to reach out to the lost with the truth and reality of the gospel.

Church planting, therefore, is one of the means for expressing God's mission, a key strategy in fulfilling Jesus' Great Commission. It is an avenue for making disciples and necessary for the transformation of cultures and societies.

Although church planting is not without obstacles, sincere efforts should be made to incorporate the practice into Christian mission. Growing and planting people groups who have accepted Jesus as their personal Savior. It is divinely ordained. The Holy Spirit transforms the hearts of those reached, but messengers are needed. . . God always grants us the opportunity to actively cooperate with Him or become obstaclesconsciously or unconsciously — to His desired purposes. 


\section{CHÁPTER 4}

\section{METHODOLOGY FOR CHURCH PLANTING \\ STRATEGIES IN NORTHERN NIGERIA}

\section{Introduction}

This chapter gives a brief history and demography of Northern Nigeria, with particular attention to the target groups (the Atyap, Baju, Hausa/Fulani, Ikulu and Kamantong), the indigenous people that occupy Zangon-Kataf area of southern Kaduna. It includes the historical background of the Seventh-day Adventist work in Northern Nigeria. In addition, the chapter takes note of the presence of other major religious organizations in the area under consideration. It ends with contextualized church planting strategies among the Muslims in Northern Nigeria beginning at Zangon-Kataf.

\section{Demography of Northern Nigeria}

The 2006 Nigerian census figures depicted in Table 1, released from the National Bureau of Statistics, show that the country's mainly Muslim northern states accounted for just over half of the country's 140 million people. Previous census results have been mired in controversy; the issue of religion and ethnicity were deliberately excluded from the questionnaire. Religion and ethnicity are major issues in Nigeria and some have hoped to use the census to justify demands for more recognition and power. It is obvious that, in Nigeria, a state's population affects its budget and, to an extent, its representation in government. More generally, in national politics, the larger a region's population, the 
Table 1

Northern Nigeria Cenus Figures (2007)*

Benue

Kogi

Kwara

Nasarawa

Niger

Plateau

SubTotal

\begin{tabular}{l} 
Adamawa \\
\hline Bauchi \\
Borno \\
Gombe \\
Taraba \\
Yobe \\
SubTotal
\end{tabular}

\begin{tabular}{r|r|r|r|}
\hline \multicolumn{4}{|c|}{ North-Central } \\
\hline Male & Female & Total & $\begin{array}{r}\text { \% of the } \\
\text { Nation }\end{array}$ \\
\hline $2,164,058$ & $2,055,186$ & $4,219,244$ & $3.01 \%$ \\
\hline $1,691,737$ & $1,566,750$ & $3,258,487$ & $2.33 \%$ \\
\hline $1,220,581$ & $1,150,508$ & $2,371,089$ & $1.69 \%$ \\
\hline $\mathbf{9 4 5 , 5 5 6}$ & $\mathbf{9 1 7 , 7 1 9}$ & $1,863,275$ & $1.33 \%$ \\
\hline $2,032,725$ & $1,917,524$ & $3,950,249$ & $2.82 \%$ \\
\hline $1,593,033$ & $1,585,679$ & $3,178,712$ & $2.27 \%$ \\
\hline $\mathbf{9 , 6 4 7 , 6 9 0}$ & $\mathbf{9 , 1 9 3 , 3 6 6}$ & $18,841,056$ & $13.46 \%$ \\
\hline
\end{tabular}

\begin{tabular}{r|r|r|r|}
\hline \multicolumn{4}{|c|}{ North-East } \\
\hline Male & Female & Total & $\begin{array}{r}\text { \%o of the } \\
\text { Nation }\end{array}$ \\
\hline $1,606,123$ & $1,561,978$ & $3,168,101$ & $2.26 \%$ \\
\hline $2,426,215$ & $2,250,250$ & $4,676,465$ & $3.34 \%$ \\
\hline $2,161,157$ & $1,990,036$ & $4,151,193$ & $2.97 \%$ \\
\hline $1,230,722$ & $1,123,157$ & $2,353,879$ & $1.68 \%$ \\
\hline $1,199,849$ & $1,100,887$ & $2,300,736$ & $1.64 \%$ \\
\hline $1,206,003$ & $1,115,588$ & $2,321,591$ & $1.66 \%$ \\
\hline $9,830,069$ & $9,141,896$ & $18,971,965$ & $13.55 \%$ \\
\hline
\end{tabular}

\begin{tabular}{|c|c|c|c|c|}
\hline & \multicolumn{4}{|c|}{ North-West } \\
\hline & Male & Female & Total & $\begin{array}{c}\% \text { of the } \\
\text { Nation }\end{array}$ \\
\hline Jigawa & $2,215,907$ & $2,132,742$ & $4,348,649$ & $3.11 \%$ \\
\hline Kaduna & $3,112,028$ & $2,954,534$ & $6,066,562$ & $4.33 \%$ \\
\hline Kano & $4,844,128$ & $4,539,554$ & $9,383,682$ & $6.70 \%$ \\
\hline Katsina & $2,978,682$ & $2,813,896$ & $5,792,578$ & 4.14吼 \\
\hline Kebbi & $1,617,498$ & $1,621,130$ & $3,238,628$ & $2.31 x^{\prime \prime}$ \\
\hline Sokoto & $1,872,069$ & $1,824,930$ & $3,696,999$ & $2.64 \%$ \\
\hline Zamfara & $1,630,344$ & $1,629,502$ & $3,259,846$ & $2.33 \%$ \\
\hline SubTotal & $18,270,656$ & $17,516,288$ & $35,786,944$ & 25.56 桨 \\
\hline
\end{tabular}

*Retrieved 01/10/2011, from the Nigerian National Bureau of Statistics, http:/www.nigerianstat.gov.ng/nbsapps/connections/pop 2006.pdf.

more it claims a right to the country's leadership. Such is the inherent controversy of the statistics; a person's religion and ethnicity were deliberately left off the questionnaire when the census was conducted in 2006 . 
As shown in Figure 1, Northern Nigeria consists of twenty states, including Abuja the Federal Capital Territory. It is sub-divided into north-central, which consists of Benue, Kogi, Kwara, Nassarawa, Niger, and Plateau states.

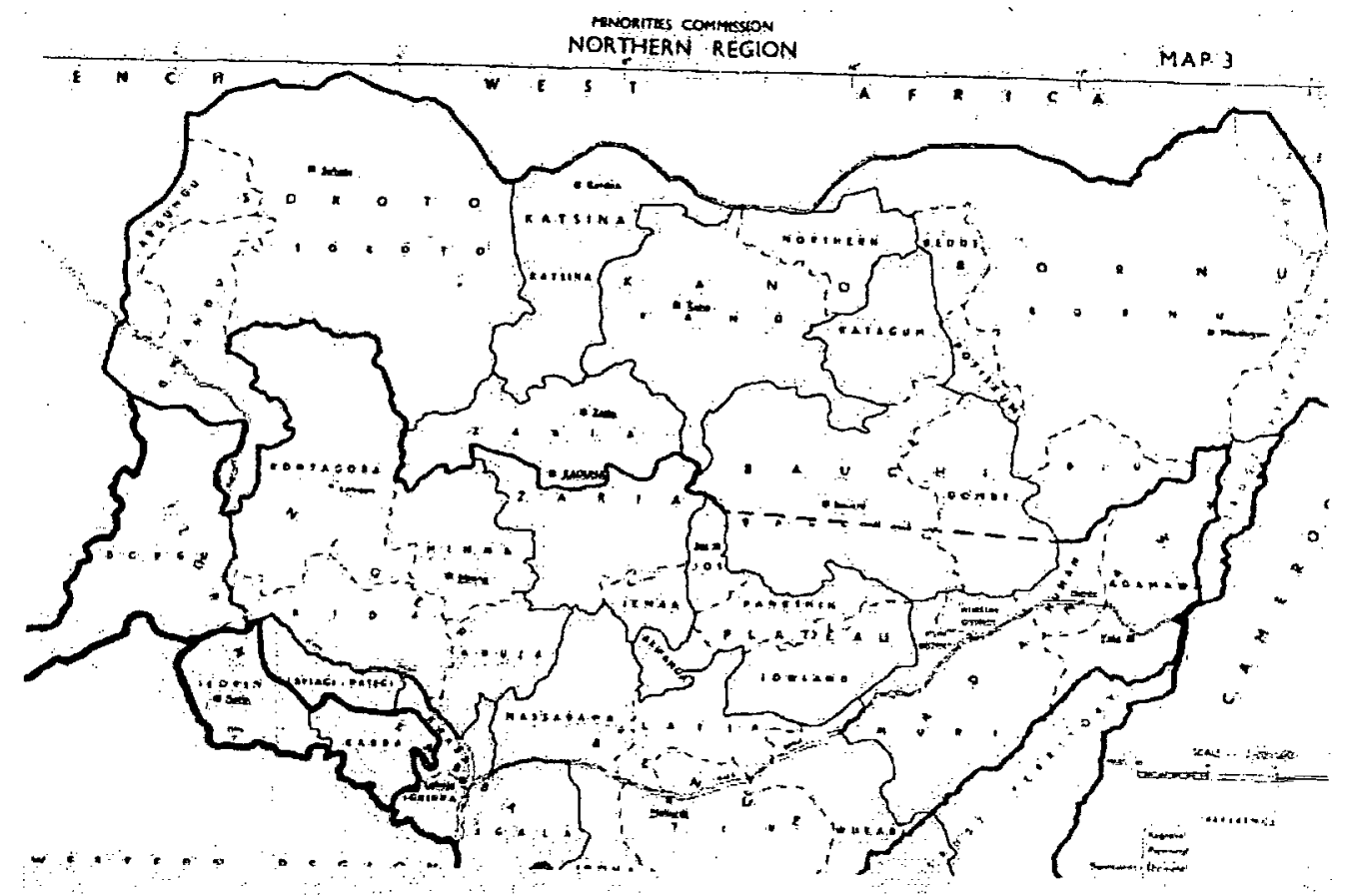

Figure 1. Map of Northen Nigeria. Retrieved 04/15/2011, from http://images.search.yahoo.com/search/images?_adv_prop=image\&fr=yfp-t-701$\mathrm{s} \& \mathrm{va}=\mathrm{a}+$ map + of + northern + nigeria.

The numerous ethnic groups in the northern two-thirds of the country are the Hausa-Fulani, the overwhelming majority of whom are Muslims, making up 29 percent of the nation. Other major ethnic groups of the north are the Nupe (5 percent), Tiv ( 2.5 percent), and Kanuri (4 percent). These percentages are estimates, based on the number of settlements, including the number of towns, villages, hamlets, and cities, with information supplied by the Nigeria Postal Services. The languages spoken in the north are numerous. English is the official language. Other languages include Hausa, Fulani, 
Tiv, Kanuri, Nupe, Idoma, Igala, Baju, Atyap, Birom, Angas, Amo, Kurama, Ham, Kadara, Kagoro, and many others.

According to the census (see Table 1), this region has an estimated population of $9,647,690$ males and $9,193,366$ females, making a total of $18,841,056$. This accounts for 13.46 percent of the nation. There is the northeast region which is comprised of Adamawa, Bauchi, Borno, Gombe, Taraba, and Yobe states. It has a population of $9,830,069$ males and 9,141,896 females, totaling $18,971,965$ people. This includes 13.55 percent of the nation. The northwest is made up of Jigawa, Kaduna, and Kano, Katsina, Kebbi, Sokoto and Zamfara states. There are 18,270,656 males, 17,516,288 females with an overall total of $35,786,944$. This forms 25.56 percent of the nation's population. A buja (FCT) is also part of the northern region of Nigeria. It has 740,489 males and 664,712 females. This gives a total of $1,405,201$ people. This figure can be estimated to 1 percent of the nation.

History and Demography of the Target Group(s)

The "Atyap Nationality" 2010 records that Zangon-Kataf Local Government Area is located at the southern zone of Kaduna state with its headquarters in ZangonKataf (Atak Nje), Zonkwa (Kurmin Bi), Kamuru and Fadan Kamantan. It has an area of $2,668 \mathrm{~km} 2$ and a population of 316,370 at the 2006 National population census. The following are the ethnic groups found in Zangon-Kataf Local Government Area: Bajju (Kaje), Atyap (Kataf), Bakulu (Ikulu), Anghan (Kamantan), Hausa, and Fulani. The area consists of four emirates: Atyap, Bajju, Ikulu, and Kamantan. Each of these emirates is led by a paramount leader--Agwa Tyap, Agwam Bajju, Agwom Ikulu, and NgbiarAnghan, respectively. 
This project is designed for the purpose of planting new churches among these five ethnic groups that occupy this area, beginning with the Atyap (Kataf) and Hausa/Fulani, who are mostly Muslims in this region. For this reason, much of this effort would be focused on these two people groups who settled in this area earlier before the arrival of Christian missionaries.

\section{The Atyap Community and Culture}

The Atyap ethnic group, also known as the Kataf, occupy the greater part of the Zangon-Kataf Local Government Area of southern Kaduna. They speak the tyap language, one of the west Plateau languages. The Atyap community believes that all members of a clan have one ancestor, and therefore encourages inter-clan and inter-state marriages. Traditionally, the states and clans had complimentary functions. The Shokwa were in charge of rainmaking and flood control rites. The Agba'ad clan had primacy in both cavalry and archery warfare, and led the army. The Aku clans were the custodians of the paraphernalia of the Abwoi religion and performed initiation rites for all new initiates.

The Aboi religion includes elaborate initiation ceremonies and believed in the continued presence of deceased ancestors. It was secretive, with incentives for spies who reported saboteurs and death penalties for revelation of secrets. For six months of the year, beginning from the month that records the first rain, in most cases, the month of April through September, women were restricted in their dress and travels. They were only allowed to cover themselves with carefully weaved leaves. They could not travel outside their community. After this, there was a celebration and lose of these restrictions. 


\section{History}

Young $(2003$, pp. 75,76$)$ explains that there are no written records, but there is evidence that the Atyap were early settlers in Zangon-Kataf region, as were the Hausa/Fulani. Both groups were in the area since at least the 1750 s, possibly much longer, and both groups claim to have been the first settlers. Atyap nationalism grew in the nineteen century, as Fulani jihadists tried to extend control in this and other parts of central Nigeria. When the British conquered the north of Nigeria in 1903, they followed a system of indirect rule. The British gave the Emir of Zaria increased powers over the Atyap through the village heads that he appointed, which caused increasing resentment.

Christian missionaries found fertile ground with the Atyap, who had rejected Islam. This served to increase tensions between the Atyap and the Hausa/Fulani. The Atyap also resented loss of land, considering that they had originally owned all of the Zangon-Kataf territory and had been illegally dispossessed by the Hausa/Fulani intruders.

\section{Historical Background of the Seventh-day Adventist Work in Northern Nigeria}

Nengel $(2005$, p. 1) sees the Seventh-day.Adventist Church as a late-comer to Nigeria. While other Christian missionaries came to Nigeria as far back as the 16th century, it was not until three centuries later that the Adventist mission arrived. And because of opposition from the Hausa/Fulani, who dominated the region after its establishment in 1914, the activities of the Adventist mission were confined to the southern banks of the Rivers Niger and Benue for almost two decades before the message was spread across the northern banks.

Nigeria is a multi-ethnic, multi-lingual, and multi-cultural country. Before the introduction of the Christian faith in Nigeria, there were two major religious beliefs: 
traditional and Islamic religions. Whereas traditional religion is the indigenous beliefs, customs, and practices based on the animistic worldviews of local people everywhere in Africa, Islam is a universal religion and it was introduced to Nigeria in the second half of the eighth century A.D.

The Adventist mission faced enormous difficulties before it secured a site to establish and develop its work in Northern Nigeria. While the early missionaries in the area were simply granted permission by the government, after securing a location to establish their work, for the Adventists, the government could grant permission only with the consent of the earlier missionaries. By implication, permission from both the government and other missions had to be sought and granted before the Adventists could open their station in the region. This was the major problem faced by the Adventist as late-comers in the northern hinterland of the rivers Niger and Benue.

\section{Christian Missionary Rivalry}

Nengel $(2005$, p. 8$)$ states that the idea of creating spheres of influence by the colonial administration was to prevent unhealthy rivalry, and to minimize open confrontation between missionaries contending over their spheres of operation. It is a fact that wherever and whenever spheres of influence were created, either for the conduct of commerce and trade, or for missionary enterprise, intense competition and clashes were inevitable. In the region north of the rivers Niger and Benue, since there was plenty of space among the non-Muslim societies for the early arrivals, there were no problems and so no accounts of unhealthy rivalry was recorded among the missionaries. In the course of time, however, with the increase in the number of sects and the expansion of their activities, the available spheres of influence significantly diminished. This was the 
situation by 1931, when Mr. John Jacob Hyde wrote his application for the Adventists to establish their presence in Zangon-Kataf.

The response of the residents in Zaria was not positive. This was because of the apparent clash of interests by both the SDAs and S.I.M. over Zangon-Kataf. The reply of McClements, the Superintendent of the SDA Mission at Ibadan, Nigeria, to the D.O. in charge of Zaria Division indicates the intractable nature of the problem. The letter of McClements reads:

Your letter ... dated 19th instant came to me a few days ago, and I must admit being somewhat surprised at its contents; however, I appreciate your thought in the matter of referring our application back to us before proceeding further with it. (2) We understand that the S.I.M. had a station at Kagoro in the Plateau Province, but we also understood that their work had not as yet extended to the Kataf people. (3) As you know, we have been deeply impressed with the situation at Zangon-Kataf and the large tribe of pagan people there amongst whom little or nothing has been done along missionary lines thus far. It seems to us that in working for these people and building up a medical work there we could have a good location, and would not be so likely to clash with other Missions as we might elsewhere. (4) We would therefore be glad if you would proceed with our application for the site at Zangon-Kataf, as it seems to be the best opening we have seen so far. (5) I am sending a copy of your letter by this mail to our Mission Board, and also to Mr. Hyde who is in England at present, with the request that they cable me if they advise us to withdraw the application, in which case I would immediately communicate with you. (p. 8)

Having analyzed the two positions by SDAs and S.I.M., the Resident of Zaria wrote to the Secretary of Northern Province on the matter, lamenting at the end that it was unfortunate that the Kataf should be denied the promised medical assistance, but under the circumstances there would appear to be no alternative but to inform the Seventh-day Adventists that their application could not be granted because of the clash of interest between SDA and Sudan Interior Mission (SIM).

Undeniably, Nengel $(2005$, p. 13) observes that there was a very tense rivalry between the SDAs and S.I.M. over the spheres of influence, particularly in the southern part of Zaria Province. Despite the intensity and hostility of the rivalry, the two bodies 
amicably settled their problem by demarcating boundaries for their respective spheres of operations. With the rivalry behind, the SDA Mission then embarked upon the task of choosing an alternative suitable site to establish and develop a permanent center for its operation in Northern Nigeria.

\section{Establishment of the SDA Mission}

The long drawn-out contest over the sphere of influence with S.I.M. in ZangonKataf caused unnecessary delay in the establishment of a permanent base of operation for the SDA mission work in Northern Nigeria. The palaver took almost a whole year before the mission, without any fear of clash, turned its attention to Jengre in Jere District of Jos Division.

Before relocating to Jengre in December 1931, Hyde had already established himself at Zangon-Kataf in the hope of building a permanent headquarters on this site for the Adventist mission work in Northern Nigeria. McClements (1931), in a progress report on the Nigerian Front, gave the following summary about the work so far in Zangon-

Kataf:

I have just returned from an extended trip up north, where J.J.Hyde is now settled since he has gone among these Mohammedans and pagan people of the north, he has been besieged by sick folks seeking medical aid. In one town, Zangon-Kataf had a hundred patients coming for treatment every day before he had been there a week. In cooperation with the enlightened chief, who is a Mohammedan, Brother Hyde started a dressing station in the village, and really I haven't seen anything like it, or nearly approaching it, since I have been in Africa. We feel that the way has been providentially opened for us in this part of the field through medical work, and it is among these people that we plan to start a small medical work in the near future. We are very glad indeed to know that the REVIEW is helping to raise some money to aid us in this work, through the Mission Extension Fund. The people of this area are divided into two classes, Mohammedans and pagans. All are anxious for us to open a dispensary or hospital here, and have given us a large tract of land for this purpose. The English officials also welcome us into the district with our medical work. So we believe the Lord has been directing us to this section of the Northern provinces in a special manner. (p. 9) 
The Development of the Adventist Mission Work

The mission station at Jengre is located on the border between Plateau and Zaria Provinces. From this strategic location, the mission combined the gospel and medical ministry in the expansion of the work among the different ethnic groups in the two provinces. However, Nengel (2005) states, "The Adventist mission was confronted with formidable challenges; progress at the beginning was slow but the patience and tact of the missionaries eventually yielded some dividends" (p. 18). Maigadi (2005, p. 52) adds that, in a region traditionally regarded a Muslim enclave, it may be interesting news to the church historian that the missionaries had to contend with conservative Islamic and other Christian missions that were already established in the area. They began from nowhere, in terms of experience, infrastructure, and institutions, yet they were determined to establish in the face of a bleak future. Other challenges the Adventist missionaries faced include language barriers, polygamy, diseases, and poverty among the ethnic groups.

The $S D A$ Yearbook $(1980$, p. 114) has it on record that a new administration began at the beginning of 1976, with foreigners again at the head. D. C. Clotheir and L. G. Clemonds became president and secretary/treasurer, respectively. While Clemonds was transferred to the Adventist Seminary of West Africa (ASWA) as the Business Manager, Clotheir remained in office until S. H. Jensen took over as president in 1979. The then secretary/treasurer was Luka T. Daniel, who retired as West-central Africa Division (WAD) president in 2008. The membership, as of June 1980, was 4,419, as can be observed in Figure 2. 


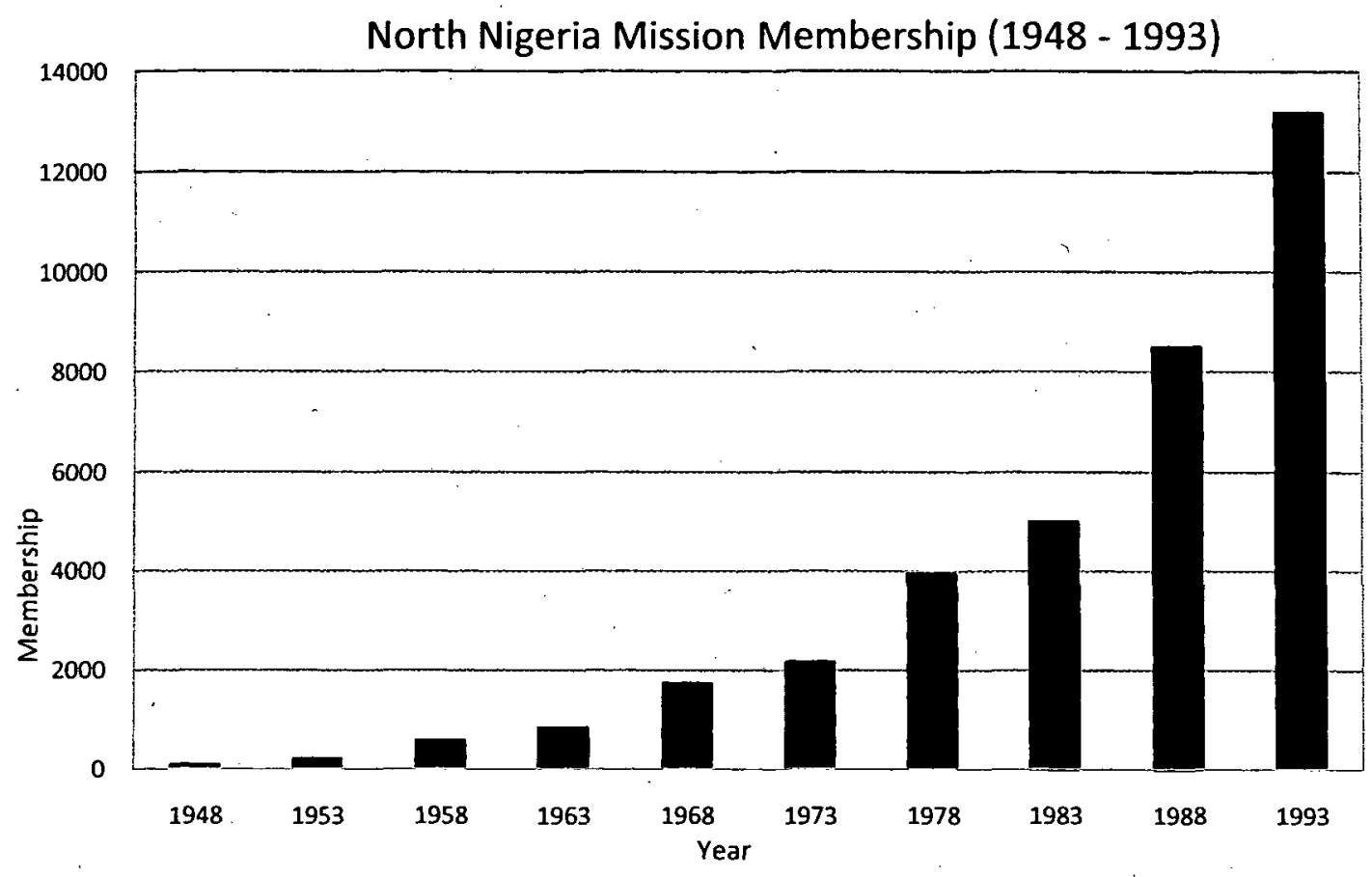

Figure 2. Northern Nigeria mission membership (1948-1993). Source: Yearbook of the Seventh-day Adventist denomination. (1936-1993)

\section{Reorganization into Two Missions}

Alalade (2008, p. 75) writes that the major rationale for the reorganization in 1993 was the vastness of the northern territory. At the time the reorganization was done, the Northern Nigeria Mission covered 18 states, including the Federal Capital Territory. The North-east Mission covers Adamawa, Bauchi, Benue, Borno, Gombe, Nassarawa, Plateau, Taraba, Yobe states and Abuja, the Federal Capital Territory, while the Northwest Mission covers Jigawa, Kaduna, Kano, Katsina, Kebbi, Niger, Sokoto and Zamfara states. Alalade notes that shorter travels would reduce travel budgets and enhance ministering. Long travels on our rough roads are energy-sapping and unsafe. Thus, it was wise to reorganize. 
At the time of the reorganization, the membership was 13,756. Pastor Ezekiel Dutse Magaji continued as president of the newly organized North-east Nigeria Mission at the old Mission headquarters in Bukuru, Plateau state. It started with a membership of 7,281. Pastor Yakubu Musa was elected the president of the North-West Nigeria Mission. Its membership at the time of reorganization was 6,475 as shown in Figures 3, 4, and 5 .

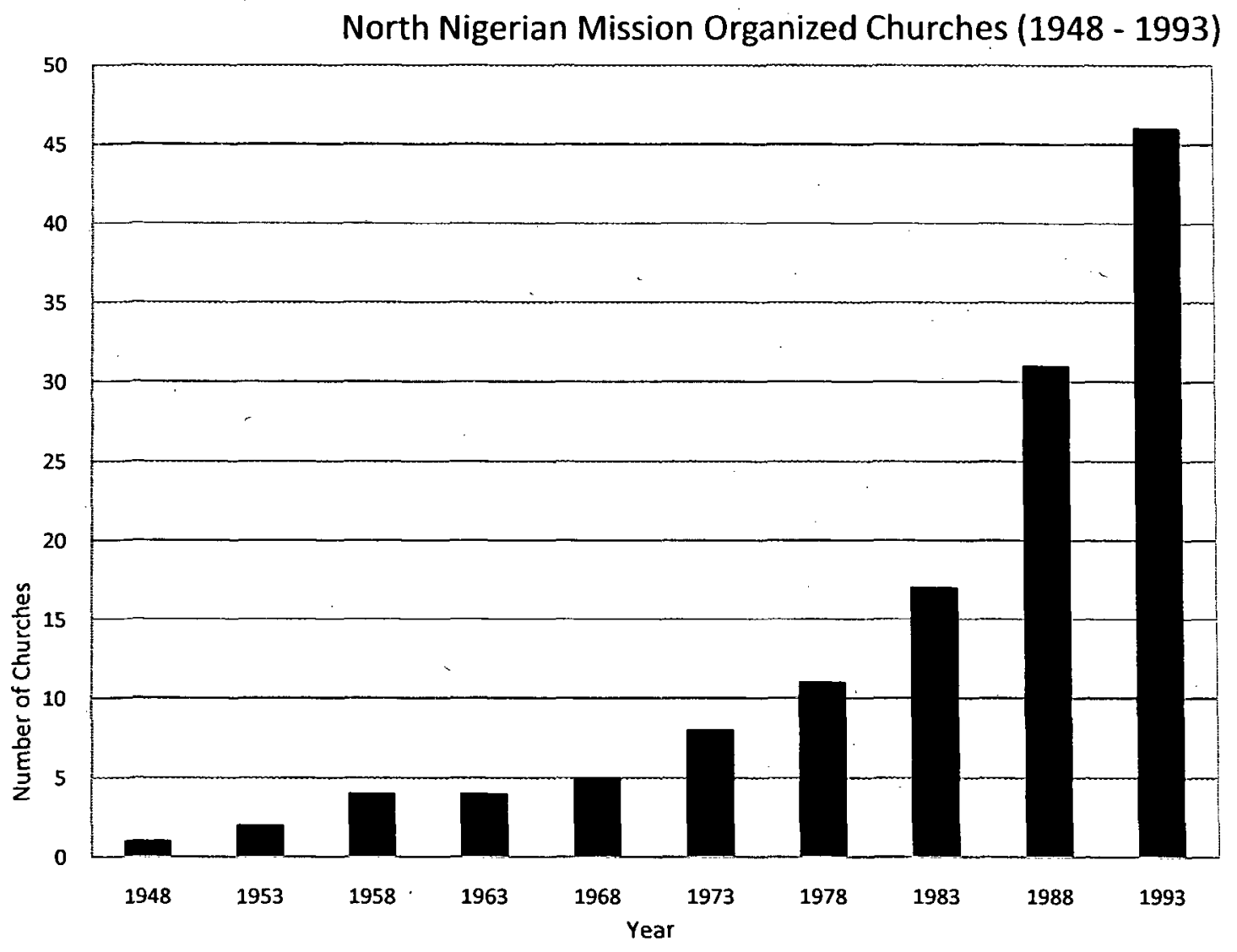

Figure 3. Northern Nigeria mission organized churches (1948-1993). Source: Yearbook of the Seventh-day Adventist denomination (1936-1993). 


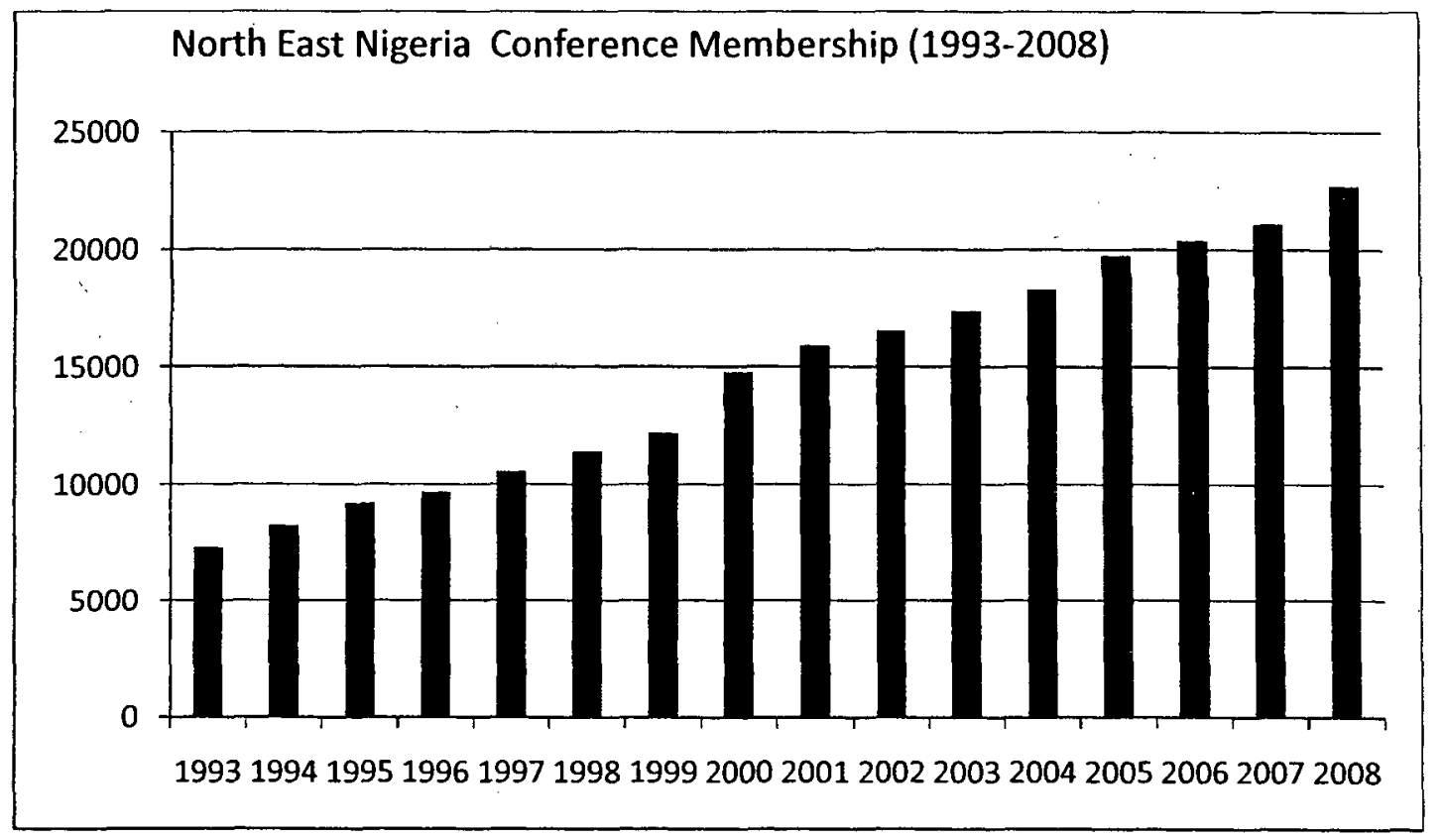

Figure 4. North-east Nigeria conference membership (1993-2008). Source: General Conference-Office of Archives and Statistics. Retrieved 1/2/2011, from http://www.adventiststatistics.org/view_Summary:asp?FieldID=C10290

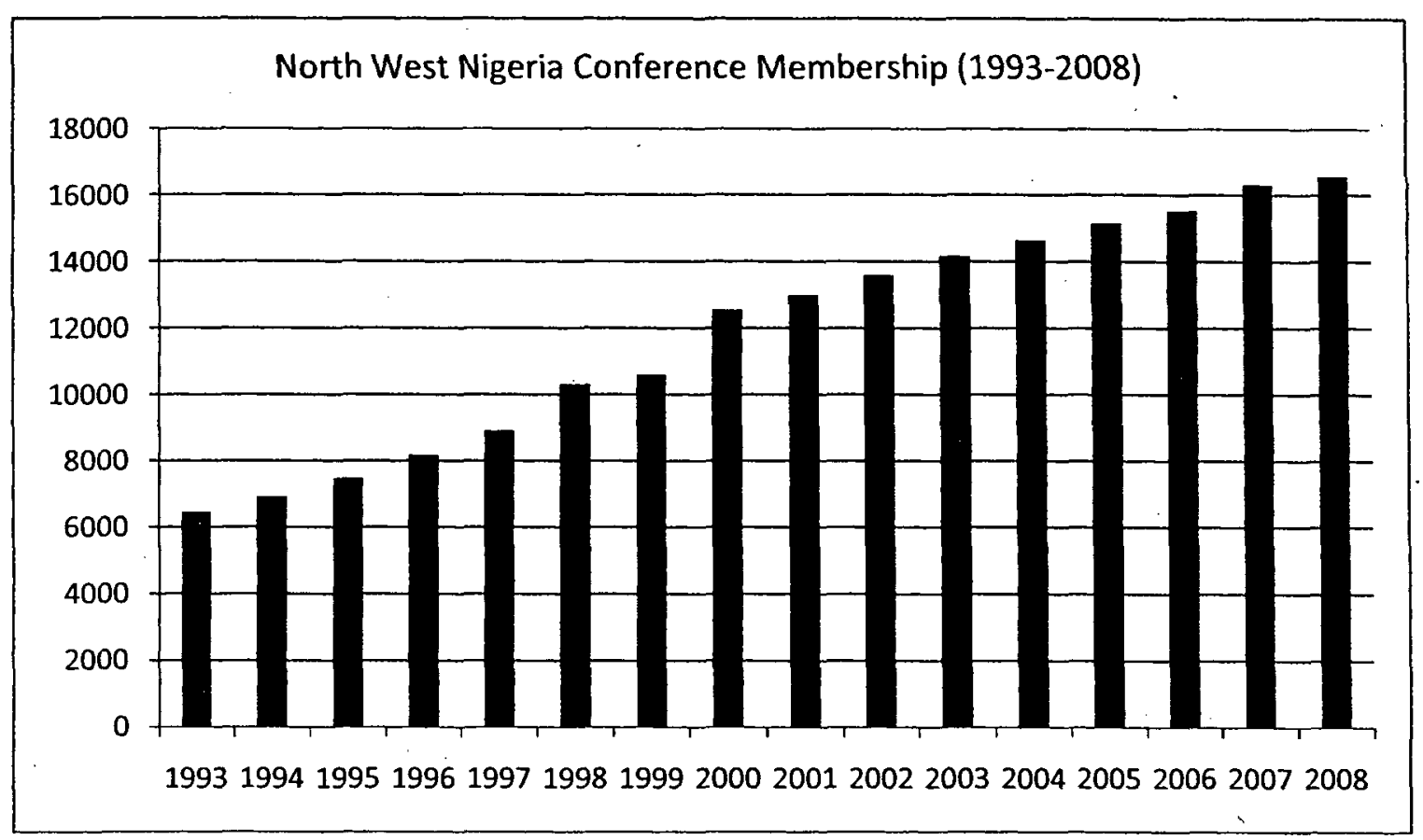

Figure 5. North-west Nigeria conference membership (1993-2008). Source: Retrieved $1 / 2 / 2011$ from the General Conference-Office of Archives \& Statistics, http://www.adventiststatistics.org/view_Summary.asp?FieldID=1485194. 


\section{Discovering the Presence of Other Religious Groups in Nigeria}

In terms of Nigeria's major ethnic groups' religious affiliations, the Hausa/Fulani ethnic group in the north is about 95 percent Muslim and 5 percent Christian. The middle belt of Nigeria contains the largest number of minority ethnic groups in the country and they are mostly Christians and members of traditional religion with few Muslim converts.

\section{Christianity}

The World Affairs Publication (2007) records that Christianity is one of the two main religions in Nigeria, making up 48 percent of the population. It is estimated that over 70 million persons in the country belong to the church. The Church of Nigeria has about 17 million members. The Nigerian Baptist Convention has about 3 million baptized members. The Roman Catholic has an estimated membership of 39 million. Alalade (2008, p. 91) has on record that, as of January, 2008, the SDAs had a total membership of 310,200 , while the Cherubim and Seraphim Church had 6,000,000 members. The Redeemed Christian Church of God, which is perhaps the fastest growing church in Nigeria today, has over $10,000,000$ members.

\section{Islam}

Islam is an important religion in West Africa. Nigeria has one of the largest Muslim populations in West Africa, with 50.5 percent of the country's population. Islam was introduced to Northern Nigeria as early as the 11 th century A.D. It was well established in the major capitals of the region by the 16th century, spreading into the countryside and toward the middle belt uplands.

Kure (2004, P.174) has it that militant Islamic fundamentalists often viciously attack the church. Christians are killed at random in an attempt to complexly wipe out the 
church in the predominantly Muslim North and to declare that the North is completely Muslim territory, an extension of the Arab Middle Eastern world. Typical Northern Nigeria Muslims are more connected to their Arab Islamic identity than to their Nigerian heritage. For them, the Islamic laws of Sharia are more sacred than the laws of the land. This is why the idea of the Church being alive and well in the northern states of Nigeria is anathema to Muslims.

\section{Chrislam}

In Africa, Islam and Christianity are growing and blending. The term Chrislam refers to a blend of Christianity and Islam that takes practices from both the Bible and the Qur'an. Chrislam or The Will of God Mission or Ifeoluwa (God's love) Mission is a syncretic religion which mixes elements of both Christianity and Islam. Unfortunately, Chrislam falls short of a helpful approach to reconciliation. Others see it as syncretism and possibly misguided reconciliation.

This Mission was founded by Tela Tella in the 1980s. The aim of this mission is to quell religious feuds among Nigerians. The sect predominantly exists in Lagos, Nigeria. Its followers recognize both the Bible and the Qur'an as holy texts. During worship services, verses are read from both the Bible and Qur'an; both texts were accepted by the congregation as true. The people of the congregation are free to shout out to Allah or God in worship. They believe that Muhammad, Moses, and Jesus were all great prophets and we need to love them all.

Table 2 shows the percentages of each of the major religious groups in Nigeria. 
Table 2

Nigeria: Facts and Figures*

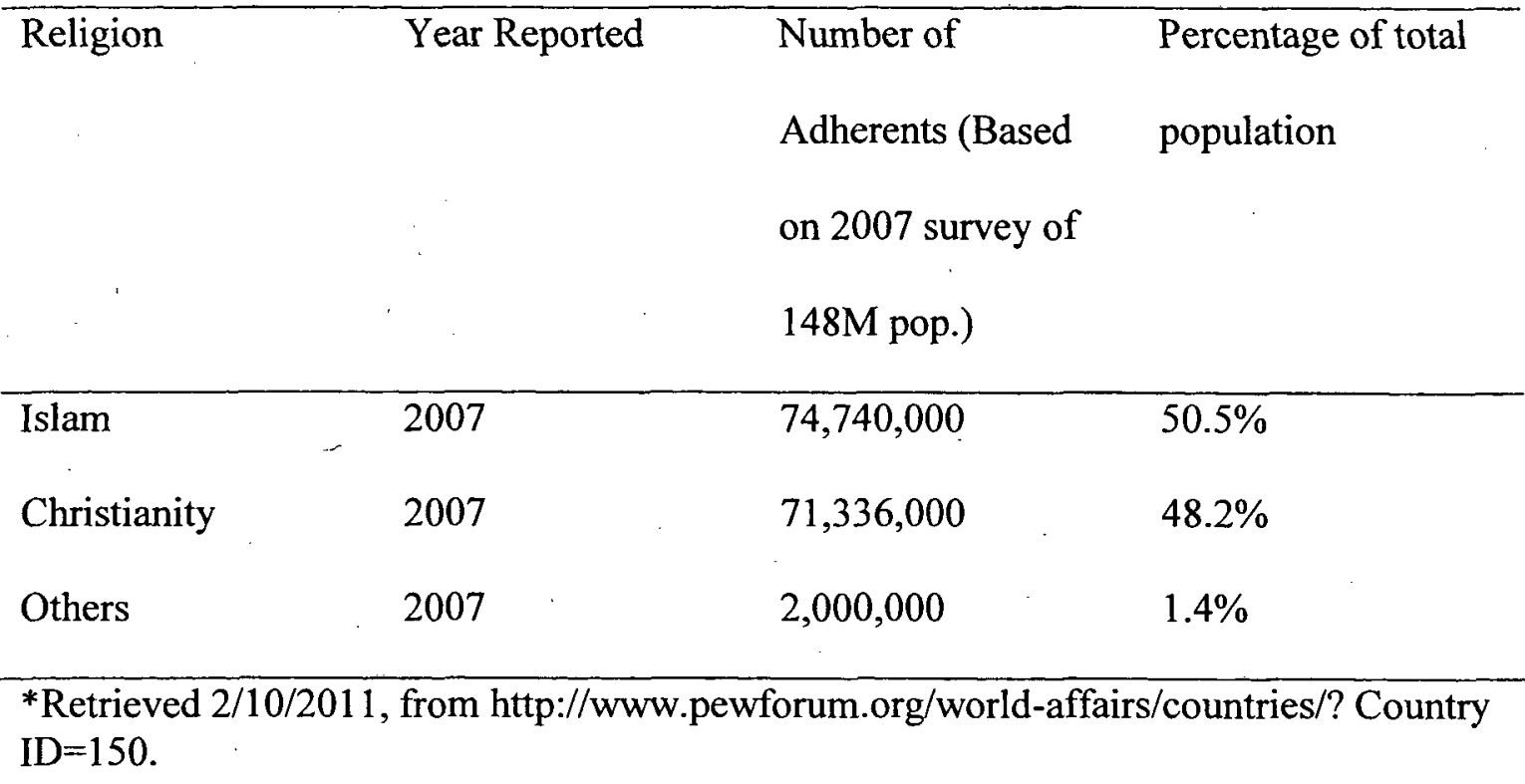

A Contextualized Church Planting Strategy

In chapter three, contextualization is defined as the presentation of the eternal truths of the scriptures within the cultural setting of a group of people. Craft $(2005$, p. 4) understands contextualization as doing whatever is necessary to make sure Christianity is expressed in ways that are appropriate to the context of the receiving group. Since the Seventh-day Adventist Church takes the mandate of our Lord to enter every community in Northern Nigeria seriously, plans need to be laid now with guidelines and contextualized strategies for planting new congregations. Congregations could be encouraged to plant more churches in both the sparsely and heavily populated areas of Northern Nigeria. However, for the purpose of this project, the contextualized church planting strategy being designed here is limited to a sparsely populated area. 


\section{Historical Mandate}

It is pertinent to note that early Adventist church leaders envisioned the spreading of the three angels' messages of love to every village, town, and city. As E. G. White 1946) observes, "Enter every new place possible and begin the work of educating in vicinities that have not heard the truth" (p. 47). In one of her visions, White (1948, pp. $28,29)$ saw jets of light shining from cities and villages, and from the high places and the low places of the earth. The results sound encouraging to us, because God's word was obeyed and there were memorials for Him in every city and village. God's truth was proclaimed throughout the world. What a great opportunity to be involved in and be a part of church planting among the Muslims in Northern Nigeria.

\section{Objective of Contextualization}

Before our dreams can be achieved, the message should be critically contextualized in order to inspire the hearts of the target audience. Bauer (2005, p. 19) understands contextualization as simply the presentation of the eternal truths of scripture within the cultural setting of a group of people. The impact of the Word is not to be watered down; rather, it should be presented to the people in a culture in such a way that they understand those principles and truths. The point Bauer is making is that it is possible to have a deep respect for culture without allowing it to water down the impact of the message.

\section{The Importance of Contextualization}

We need to know why contextualization is significant to enable a successful church planting endeavor. Without a careful contextualization, the church planter, whose aim is to communicate the gospel, runs the risk of misrepresenting the Good News, and 
making it harder for people to accept Jesus as Lord and Savior. Martin (2005, p. 35) adds that true contextualization should aim at making an attempt to communicate the gospel in word and deed to establish the church in ways that make sense to people within their local cultural context. Basically, Martin is saying that Christianity should be presented in such a way that it meets people's deepest needs and penetrates their worldview, thus allowing them to follow Christ and remain within their own culture.

\section{Issues in Contextualization}

Contextualization as it has been discussed in the project dissertation may appear to be a theoretical concept, but it is more pragmatic than theory. Approaches made from a Christian perspective to a Muslim involve reaching across, not only ethnic barriers, but cultural, language, and world views. The following is a discussion of the possible challenges and arguments for and against contextualization:

\section{Historical Case For and Against Contextualization}

Bauer (2005, p. 22) notes that, throughout the history of Christian mission, there has been a battle between those who see little need for contextualization and those who are so sensitive to culture that they allow culture to dominate the biblical message and, in the process, distort that message. These two extremes, of course, have been called by various names. Heibert $(1985$, pp. 184, 185) refers to these extremes in contextualization as "rejecting of contextualization," where there is wholesale denial of the validity of the old cultural ways, where everything in a culture is viewed as evil, pagan, or unfit to be used to communicate the Christian message; and "uncritical contextualization," where cultural practices are accepted wholesale with little concern that the result is gross 
syncretism." Hesselgrave (2004, pp. 5-7) refers to the arguments as undercontextualization and over-contextualization.

\section{Over-Contextualization}

Over-contextualization is the watering down of Christian distinctiveness, the blending of Christianity and traditional religions with the result that the gospel is distorted and gross syncretism exists. It is sensitive towards culture. Overcontextualization overlooks the fact that there is good and evil in every culture. Sin is found in the cultural practices of every society, and for the Christian witness not to allow the Word to root out such practices goes against the very purpose of mission. Heibert 1985, p. 185) adds that the gospel calls men and women to a new life in Christ, which predisposes a turning from the evil of the past.

\section{Under-Contextualization}

Under-contextualization, on the other hand, occurs when the Christians introducing the Good News to a people group label most of the culture as pagan and unfit to carry the gospel message. When whole areas of a culture are written off as not fit for use in the communication of the gospel, the results are often less than what was desired. When under-contextualization is practiced, Heibert (1985, pp. 184-85) suggests three major areas of weaknesses that could surface:

1. Creation of a cultural vacuum: a tendency, when taking customs and practices away from a people and in the process of labeling them as pagan, to create a cultural vacuum. Christian missionaries then try to fill the vacuum by giving the people substitute customs and practices from the missionaries' home culture. This process often results in 
the church in that part of the world being viewed as foreign, strange, and dominated by foreign ways and practices.

2. Creation of an underground culture: Under-contextualization causes many of the cultural practices of a people to go into hiding, to go underground, with the result that the people continue to practice many of the old ways in secret. This type of syncretism is caused by not dealing with the old ways and by not applying the principles of the Word to the issues in the culture. The result is syncretism, as the old fears and beliefs exist underneath, but with a veneer of Christian practices on the surface.

3. Creation of cultural norms: Under-contextualization causes church leaders and missionaries to assume the role of policemen. When the local body of believers is not allowed or encouraged to apply the principles of God's Word to their own culture, they learn to live by the rules given to them by the first missionaries. They never grow in their faith to the point where they can assume their proper role as part of the world hermeneutical community of believers who discern the leading of the Holy Spirit. In such situations, church leaders are the religious police.

\section{Critical Contextualization}

Heibert (1985, pp. 186-7) has suggested an approach to contextualization that has come to be known as "critical contextualization." It is my desire to apply this process in this design for a church planting strategy in Northern Nigeria. This is a four-step process that begins with a deep appreciation for the Word of God.

First, people who are coming to Christ must be brought to a position where they are willing to deal biblically with all areas of their lives. This includes their cultural norms and lifestyles. Cultural practices must agree with biblical principles. 
The second step is to lead the group in looking uncritically at the cultural item or practice. This step involves gathering information. Understanding is sought concerning the deep issues and meaning of the cultural practice.

The third step involves applying biblical passages and principles to the cultural item in question. What aspects of the practice are incompatible with principles of the Word? What aspects are neutral? What aspects are opposed to biblical principles?

The fourth step is the hardest for most of us (church leaders) to practice, letting the local people, under the leadership of the Holy Spirit, join in the decisions of what they can do and what they cannot do in the light of their understanding of biblical principles and the leading of the Spirit. This is an interactive process where local people are often challenged by the missionary or church leader to look at local issues in new ways and see things they had never seen in their culture before.

The topic of contextualization is relevant to the church planting endeavor because every person and every people group in God's creation has the right to hear the gospel in understandable terms. We will try not to allow non-theological barriers that keep people from accepting Jesus Christ as Lord and Savior to be created.

Implementation of Critical Contextualization in Northern Nigeria As we seek to increase our mission activities among the Muslims of Northern Nigeria and the Atyap people group of southern Kaduna, in particular, and as we plan to plant churches in these areas in an effort to bring them to faith in Jesus Christ, we will seek for the Holy Spirit to help us to try not to make them Adventists before they are Christianized. 
A Design for Muslim Evangelism in Northern Nigeria

We have discovered from the literature reviewed in chapter three that a combination of restrictions on religious liberty in Islamic nations, group pressure from the Muslim community, and severe Shari'ah law, in most cases, makes any public method not only ineffective but, in some cases, dangerous. We found that it is against the law to proselytize. This means that, among Islamic people, few names of interested persons are obtained through public advertisements. This leaves friendship as not only the most effective but often the only method in Northern Nigeria.

\section{Friendship Evangelism}

Schantz (1993, p. 16) understands personal evangelism as the method where witnessing is carried on at the individual level. McGavran (1955, pp. 10,23) underscores the fact that peoples become Christian fastest when less change of race or clan is involved and the process of extracting individuals from their setting in Hindu or Muslim community does not build a church. On the contrary it rouses antagonism against Christianity and build barriers against the spread of the Gospel. My submission on this is that even before a clan and or community is reached, the process in some instances, usually should begin with an individual. Thus, I have a strong conviction that people can also be brought into the kingdom as individuals, and probably one of the most effective means is the power of the appeal through friendship and the ministry of the Word and of course, the influence of the Holy Spirit. Kure (2004, p. 183) observes that among the Fulani Muslims, once the head of a clan gives his life to Christ, there is a high likelihood that the rest of the clan will follow suit. 
Opportunities for personal evangelism are available in Northern Nigeria, where both Christians and Muslims and even animists mingle and interact. We meet with Muslims in market places, factories, or schools, in business offices or social gatherings. Sometime they can be neighbors, fellow workers, business contacts, and fellow students.

An observant Christian will find or even create opportunities. It can be done by sharing hospitality, friendliness, and helpfulness, even by asking a favor. It can happen in the most unexpected places. Fruitful contact with Muslims who want to know more about Christ occurs as a natural thing as one goes about his or her daily activities.

Bearing in mind the theological foundation for church planting strategies in chapter two and the review of literature that followed, the following guidelines have been gleaned, which could enhance our attempts to share our faith with the Muslims in Northern Nigeria.

\section{Friendship}

Genuine friendship is the most important condition for establishing a good and amiable relationship with a Muslim and, in fact, with our Muslim friends in Northern Nigeria. First of all, there must be some personal contact. It is of utmost importance that mutual confidence and understanding is brought about as a valid foundation for meaningful communication. An appreciation expressed for a favor or a courtesy, a friendly word for a service, a helping hand, an apology when the situation requires it, and a spontaneous attempt to have a conversation are all positive factors which will help to establish friendship and communication. 


\section{Knowledge and Information}

Another important factor in making friends and gaining respect with the Muslims in Northern Nigeria is the need to have an elementary knowledge of the religion of Islam, its belief system, rituals, rules, and regulations. Christ used this significant area when $\mathrm{He}$ met the Samaritan woman (John 4) by asking her to do him a favor, requesting a drink of water. Before He engaged in His witnessing activities, He put Himself in the world of the receiver, made Himself a debtor to her, enabling her to keep her dignity. Her role was to be a generous giver and not a humble listener and receiver. This principle is of extreme significance in both our social work and outreach activities among our Muslim friends in Northern Nigeria.

\section{Hospitality}

Hospitality is, without doubt, the surest way to a Muslim's heart. Having served in the midst of Muslims for about twenty years now, I am fully convinced that hospitality is a virtue among them. Among the Hausa-Fulani, when a friendship has been established they say, "Akwai gishiri sakanin mu," which means there is salt between us, we have eaten together and are now friends. The act of accepting an invitation to eat together with a Christian is saying "yes" to friendship, and it is one of the most effective means of breaking down prejudice. Adventists, of all Christians, with dietary rules similar to the Muslim's own, can use this common ground to mutual benefit. Hospitality should be seen as a two-way street: Usually it begins with an invitation from the Christian. Then he or she accepts an invitation to the home of the Muslim. 


\section{Listen and Learn}

We are to act wisely by listening to our Muslim contacts. He or she is both willing and prepared to talk about his or her religion. It is pertinent that we do not engage in discussion on doctrines in which Christians and our Muslim friends differ until a mutual relationship of trust has been established. Mortenson (2009, p. 17) underscores the paramount importance of taking time to build relationships, while simultaneously affirming the basic truth that, in order to get things done, it is essential to listen with humility to what others have to say. There are areas of doctrinal conflicts where Muslims are not allowed to listen to critics. The Muslim has no right to discuss divisive issues relating to Allah, Muhammad, or the Qur'an.

\section{Personal Conversations}

Personal conversations are more important than group discussions. We will be careful that invitations to attend church or Christian meetings do not take place before a natural and relaxed friendship has been established. Muslims in Northern Nigeria are always under group pressure from concerned fellow Muslims. Family and fellow compatriots observe them constantly. With their strong ties of solidarity, they will not only observe the doings and goings of one another; they will also monitor non-Muslim activities, attitudes, and friends.

\section{Loss of Face Can Mean Loss of Faith}

As already mentioned, the Christian is counseled to avoid discussions on doctrinal differences until a relaxed friendship has been established. Admittedly, in a religious dialogue with Muslims; a point will soon or later come when differences and even confrontations are unavoidable. We must always remember that, in Islamic culture, it is 
not only embarrassing but humiliating to lose face. When one is able to meet arguments with more convincing facts, one must always make sure that the Muslim opponent is never ridiculed or humiliated. It can be tempting to win an argument, but it can easily result in losing a friend. This is certainly the case when the discussion takes place in the presence of other people. In such cases we must be as wise as serpents and as harmless of doves.

\section{Avoid Criticism}

Shantz (2003, p. 145) explains that conversation with a Muslim can easily develop into a discussion of the relative advantages of Christianity compared with Islam, Christ with Muhammad, the Bible and the Qur'an. Generally, such debates are futile. The Christian should carry a positive testimony of his belief in Jesus. Comments and criticisms of Islamic conditions and standing, such as their Prophet's conduct, the strict punishment for transgressing the Shari'ah law, the morals of individual Muslims, or their

religious rituals will, in general, fall outside conversations of these kinds. Such discussion should take place in the spirit of objectivity, honesty, and reliability.

\section{Relationships between Sexes}

Among the Muslims in Northern Nigeria, relationship between the sexes is a sensitive area. Christian openness in such a relationship, even the most innocent, can easily be misunderstood and condemned as immoral. There must be a careful, yet . friendly, reserve between Christians and Muslims of the opposite sex. As a rule, men should cultivate friendships with men, women with women. In Northern Nigeria, Muslim women are veiled, and in some cases are under purdah, to protect them from strangers. When in such conditions, they cannot be visited by men. However, visits and 
conversations with other women are allowed. This opens up numerous opportunities for Christian women to be involved in personal evangelism, where they can make full creative use of their talents and energies.

\section{Learn Their Language and Culture}

The Hausa/Fulani who form the highest percentage of Muslims in Northern Nigeria are highly against the Western lifestyle. Before proclaiming the Gospel, it is essential that we learn the Hausa language, and, if possible, a little Arabic. Following the instructions Jesus gave His 72 workers, they entered the homes of those who welcomed them, eating and drinking whatever was offered (Luke 10:17). They sought roles in their new culture that made sense to the people. They maintained attitudes of servant hood and humanity. We will have to minimize the social and cultural distance between us and the Muslims in Northern Nigeria to whom God calls us.

\section{Felt Needs}

To enable an effective witnessing experience with Muslims in Northern Nigeria, social involvement needs to be taken into consideration. Social interaction often provides important entering wedges for witnessing to Muslims. In this approach, it is important that we meet people's felt needs, which may vary from place to place. The need may be for food, clothing, medicine, or educational facilities. It may include the practice of witchcraft and charms.

While Muslims confess the greatness of God, many live in fear of evil spirits. Their religion teaches that there is one God and that there is no mediator between God and human kind. Yet countless Muslims seek someone to manipulate magical powers. They believe that all of creation pervaded or inhabited by spirits or souls, that all of 
creation in some sense animate or alive. People try to influence these spirits by using magic or rituals intended to harness their supernatural power for human ends. These practices involve efforts to appease these spirits, to bring blessings to themselves, or to put curses on their enemies.

The message to our Muslim friends must be "how God anointed Jesus of Nazareth with the Holy Spirit and power, and how he went around doing good and healing all who were under the power of the devil, because God was with him" (Acts 10:38).

\section{Use of Literature}

If carefully selected, Christian books and tracts are excellent tools; a good basic kit of books which can be put into our Muslim friends' hand can be a help. The Bible itself is the most powerful witness. It is the power of God for the salvation of everyone who believes (Rom.1:16). Thus, it is required that we encourage our Muslim friends to read the scriptures.

\section{Fruitful Practices among Muslims}

Don Allen (2008) in 'From Seed to Fruit: Global Trends, Fruitful Practices, and Emerging Issues among Muslims' edited by Woodberry (2011), defines fruitful practices as, "a benchmark of applied wisdom, not an exhaustive catalog of formulas. They are descriptive, not prescriptive. They do not replace the "God factor," and are not necessarily universal in scope." (p. 107). As a benchmark, the fruitful practices are a description of effective works among Muslims, but are not a prescription of detailed instructions to follow. While fruitful practices report what we see happening among us, there is no substitute for prayer and reflection. Certain fruitful practices among Muslims have been suggested as follow: 
1. Aiming to witness through social and relational networks (families, neighbors, community groups, etc.) as natural bridges to the formation of fellowships or churches. Muslims are much more comfortable with group-think than personal-think. Often, people are more confident in the approval of a group rather than their own ability to make a decision on something that is strange or foreign. (p. 93)

2. Seeking to communicate a culturally relevant message by using Scripture that addresses worldview issues and creates spiritual hunger. The use of local knowledge as Paul did at Athens (Acts 17:16-34) could be fruitful. Muslims share folk tales and adages. It should be noted that Jesus' "good Samaritan" story challenged his listeners. (p. 94)

3. Communicating the Gospel in the heart language of the people except where globalization has made the heart language less important. However, the race to catch up with globalization has made it such that we need not wait until we master the heart language before we pass on the gospel. (p. 95)

4. Seeking to be culturally appropriate (in dress, language, customs, hospitality, etc.) This principle takes on different forms. Some aspects such as modest clothing and abstaining from alcohol are common sense. Other issues are more complex and harder to know how or what to change, such as insider terms used to describe God and religious experience. (p. 96)

5. Developing leaders with methods that fit the local context. The mentoring of leaders is planned and normally non-formal such as apprenticeship. Although local leaders could be bottlenecks avenues for their community, yet we could look for existing influencers and release them quickly. They may not have to go through extensive training. (p. 86)

6. Sharing the Gospel in story form for oral societies. It has been discovered that the written Scriptures are best for people who are used to reading and writing; and the word in story form is best for oral cultures. (p. 85)

7. Working closely with new believers and modeling the Christian life. To develop a strong relationship with a Muslim background believer, the messenger must demonstrate authenticity. This takes humility (a willingness to learn and admit fault) and availability (enough contact points to model a Jesus-centered lifestyle.) (p. 104)

8. Being bold in witness and willing to risk. Boldness and risk are considered most important by those working among the oppressed. In some settings, boldness is required to hand out scriptures; in others it may take boldness to approach a government official for permission to carry out a community development project. It is taking a risk just to live in some situations. (p. 97) 
9. Seeking opportunities to pray for the personal needs of their friends in their presence. Every opportunity should be sought to pray with people, whether they have rebellious teenagers, economic problems, or problems with their neighbors, but most often people who are sick should be prayed for. Praying for supernatural intervention (healing, demonic deliverance, dreams, etc) and doing their part when God answers. The power of the Gospel is expressed in this way. (p. 98)

10. Learning culturally appropriate ways of confronting sin and restoring a repentant sinner. Local proverbs, stories and indirect approaches should be used to confront and to correct individuals who have sinned or committed some offence. (p. 106)

11. Using evangelistic tools practices that are reproducible. The concept here is that what I learn; I share it with someone else. (p. 100)

12. Using various means to share the Gospel (diversify). Numerous helpful methods could be used in sharing the Gospel, from music concerts and sports to Bible study with an individual. (p. 101)

13. Maintaining a respect for gender: normally, men disciple men, women disciple women. Although this appears to be an obvious rule of practice, there are many stories of exceptions. In one-on-one situations, it is best to keep one gender only. (p. 106)

14. Using the Bible as the central source for life, growth, and mission. Scripture is the window into the heart of God, showing us his character and purposes. It reveals the way God views the unfolding of history and creation. The Bible's truths must be at the heart of the emerging church, establishing the DNA of local body as people who accurately handle the Word of truth (2 Tim 2:15), and as people who listen and obey. (p. 116)

15. Creating indigenous worship forms in their heart language (e.g., writing their own songs). Muslim background believers in community can best discern which forms of worship are most appropriate for the occasion, even if they seem strange to foreigners. Creating indigenous worship forms allows free expression of devotion, and can be naturally attractive to non-believers. (p. 117)

16. Sharing meals and the Lord's Supper, and practicing hospitality in appropriate ways. In many Muslim cultures, hospitality and sharing a meal are sacred trust, a bond that cannot be betrayed. This tradition resonates powerfully with the Lord's Supper as a context of bonding, blessing, peace, and reconciliation within the community, and with a universal church across cultures and history. (p. 118) 
17. Seeking to bless and transform their wider community. The concept here is that of blessing without discrimination. Any benefit should go to all members of the surrounding community, not just believers. The blessing of local societies covers a wide range of activities, mostly tailored to the felt needs in the community. (p. 123)

18. Promoting accountability to one another. Genuine accountability requires trust within the bounds of personal relationship among believers. It is the essence of discipleship. It is more easily established in small groups where people are more intimately acquainted with each other, especially if they are peers, close in age and stage of life. (p. 125)

19. Commonly meeting in homes or other such places, rather than 'church' buildings. After relational networks begin coming to faith and new believers are mentored, the next step is the forming of a house fellowship. House fellowship thrives most when they are intentionally networked with one another, so that despite their smallness they can enjoy a sense of wider community identity, mutual support and encouragement. (p. 126)

20. Modeling leadership through relationship more than through institutions. Jesus sets the example in the New Testament with his disciples. He did not do training in a formal way, but by doing ministry with them and spending time with them. He taught them through stories, experience, and living life together. (p. 133)

\section{Bible Storying}

Another avenue for interacting with the people we meet is Bible Storying.

Colgate (2008, p. 221) supports the concept of Bible storying. He asserts that the telling of Bible stories is undoubtedly one of the fruitful practices that God is using today to reach unreached peoples (see Appendix D for Core Bible story list).

\section{What Is Bible Storying?}

Terry (2008) defines Bible storying "As the intentional and uninterrupted sharing of God's Word primarily as stories" (p. 2). These stories are usually supplemented with culturally appropriate learning experiences that are listener-sensitive. The story may be 
told as part of a strategy of telling many stories leading to an invitation to believe, or may be only a few stories during an evangelistic encounter or a ministry opportunity.

\section{Objectives of Bible Storying}

The characteristics of Bible storying being intentional speaks to the fact that Bible stories are told for definite purposes, for achieving objectives such as 1. Evangelizing unbelievers, 2. Planting a church among new believers, 3. Discipling new believers, 4 . Training emerging church leaders, and 5. Ministering to felt needs during times of crises as a prelude to evangelism.

\section{Prayer}

White (1995, p. 23) emphasizes the importance of prayer. As church planters, we are a savor of life unto life, or of death unto death. The position the church planter occupies is a fearful and responsible one. We are admonished to come very near to God in supplication, and we will be like trees planted by the rivers of water, whose leaves are always green. As church planters, we need divine power which God is willing to give.

In other words, Sister White believes that methods alone are insufficient in an endeavor to reach Muslims with the gospel. God does not require eloquent prayers and logical reasoning from us, but only a humble contrite heart, ready and willing to learn of Him. The praying church planter who has living faith will have corresponding works, and great results will attend his labors, despite the obstacles of the enemy of God.

The concept of prayer is highly supported. Much of the time, our prayers are simplistic. We ask God to keep us and our friends safe and healthy, rarely asking specifically for the deep, the powerful, or the seemingly impossible. If we are to persevere in prayer for the Muslims, we need to discover the thrill of encountering God's 
presence, joining Him in the working out of His will. When we have experienced this kind of prayer, we will want to do so again. Although Muslims rarely see us pray, yet we believe that when we pray for them, our petitions ascend to God.

\section{Description of Mission Strategy and Implementation}

Herbert (1978, p. 68) underscores the fact that Christian evangelism, because of consistent organized effort in the Muslim world since the beginning of the colonial era, has made little progress. This is also the situation in Northern Nigeria. Muslims who make up almost 95 percent of the population seldom hear or understand the gospel. And without proactively equipping the laity and clergy with the necessary training and knowledge, Muslims may never be brought to the light of Jesus Christ.

White (1898) adds that, "The Lord has given His church a special work of personal service to do. God could have sent angels to work for the reformation of people, but He did not do this. Humanity must touch humanity" (p. 1). There is, therefore, need to design and implement a curriculum for equipping Adventists to meet this challenge. It is obvious that every successful strategy needs a plan. A detailed strategy, along with a plan to enhance sensitivity among the laity and clergy towards creating enthusiasm in sharing their faith with our Muslim friends and the indigenous people of Zangon-Kataf, must be put in place.

There are several methods of presenting the gospel to Muslims; but for the purpose of this project, which is limited in scope, I have chosen eight significant areas that may be useful in Muslim evangelism in Northern Nigeria. (1) Training programs on interfaith understanding between Adventists and Muslims will be developed (see Appendix C). (2) I will study-more books on other Christian denominations' perspective 
and methodology in witnessing to Muslims and share with the Church planting team. (3) Seminars for members on how to witness to Muslims will be conducted. (4) Twenty-eight Global Mission Pioneers for North-east and North-west Conferences will be trained (Appendix C). (5) Gerald Whitehouse's materials prepared for comparison on religious worldviews between Adventism and Islam will be studied and used for the seminar for Muslim evangelism (Appendix C). (6) The Official Statement on Islam by the SDA Church (TED) to Provide "Relationship Tools" will be studied and shared with the church planting team in Northern Nigeria (Appendix C). (7) Interview questions put to church planters in Northern Nigeria will serve as a guide (Appendix B) would be a guide to the church planting team and (8) Core Bible story list will be followed (Appendix D).

\section{Training Program}

A training program will be designed to strengthen the clergy and laity. This training will be based on a number of sequential modules. These modules will only be taught after previous instructions have been fully understood. The training will serve as a motivating factor and educate members for Muslim evangelism (see Appendix C).

\section{Seminars}

Dayton and Fraser (2003, p. 43) emphasized the fact that some of the commands directly to Christians and the church are to care, nurture, witness, worship, give study, pray, seek spiritual gifts, and be holy. These are attitudes that will draw souls to Christ. It is important that members receive appropriate training to enable them to witness, particularly in difficult situations like the one in Northern Nigeria where there are frequent religious crises. 


\section{Christian Denominations' Methodology}

Christians of other denominations have made concerted efforts to reach the Muslims in Northern Nigeria. The Roman Catholic, Protestant, Pentecostal, and Seventhday Adventist Churches are all involved in witnessing to Muslims. Protestant missionaries, in particular, have been in search of new methods for Muslim outreach.

Adventist Statement on Islam (2007) states in part, "We believe that among people of all faiths, God has, through history, preserved a people of authentic submission in the face of apostasy, oppression and persecution. We acknowledge that within Islam there are such people... Within this group of sincere believers we see potential partners for further exploring our spiritual understanding of the one true God." The Statement ends with a call for Adventists to commit to "honesty, fairness and respect in describing Islamic faith," and vice versa.

\section{Training of Global Mission Pioneers}

The General Conference of Seventh-day Adventists is paying some attention to the $10 / 40$ window. These are areas of the world from ten to forty degrees north of the Equator, beginning from the northern parts of West Africa up to Japan, where most of the world's least evangelized people live. Thus, in the middle of 2006, the Global Mission Director of the SDA Church embarked on funding 28 Pioneers in Northern Nigeria. I was privileged to mentor and also give training to 14 of these Pioneers while I served as the North-east Nigeria Conference evangelist between 2006 and 2008. Eventually, they were posted two-by-two to minister in 14 different Muslim communities. The results were very encouraging, because, through their efforts for the first two years, a little over 100 baptisms were recorded. 
It is pertinent to mention here that these Pioneers were contracted for two years only. However, what followed afterwards is also worth noting; the two conferences were able to absorb all these 28 Pioneers. Suffice it to say, there should be continuity in giving training to these pilot laity. My plan, therefore, is to provide further training to these laymen at the completion of this project. A training program has been prepared for this reason (see Appendix C).

\section{Conference Support}

In this chapter we were able to discover the historical background of the Seventhday Adventist work in Northern Nigeria. It is worth mentioning that the effort that began in a small way in 1931, from a little village has spread to 20 northern states. It is encouraging to note also that presently there are two conferences in the north with a membership of a little over 40,000 . The Seventh-day Adventist churches in Northern Nigeria work as a team; this has brought about tremendous progress in the area. It is worth mentioning that the 'Other Sheep Outreach' which was introduced in 2006 has brought in converts from Islam in their number. By August 2007 we had a total of 19 converts from Islam in the North-east Nigeria Conference alone.

\section{Meeting the Financial Cost}

The area of finances is another essential dimension of such a church-planting ministry in a region like Zangon-Kataf local government. For effective implementation of this project, I have plans to consult with the two conferences' executives (NENC \& NWNC). After consulting with these leaders, a formal letter requesting for approval for the implementation would be tendered. I hope to do this as soon as I return to my duty post, possibly by the middle of 2012. Once approval is granted, I will prepare a budget 
for the training of the first team (28 Global Mission Pioneers) for church planting in Northern Nigeria (see appendix C). An estimated annual budget for the church planting ministry in Zangon-Kataf local government area for three separate training sessions for 7 days for each of 28 Global Mission Pioneers, 70 pastors and a weekend for 150 lay leaders (using the Nigerian currency 150 naira $(\mathrm{N})$ equals $\$ 1$ ) is as outlined below:

1. Per diem for 28 Global Mission Pioneers-N500 x 7 days $\times 28=N 98,000$

2. Salaries of 8 church-planting workers at an average monthly stipend of $N 20,000$ per worker for a year $=\mathrm{N} 1,920,000$

3. Per diem for 70 pastors would be $\mathrm{N} 500 \times 7$ days $\times 70=\mathrm{N} 245,000$

4. Cost of feeding 150 lay leaders for three days/weekend training for Muslim evangelism $=\mathrm{N} 500 \times 3$ DAYS X150 $=\mathrm{N} 22,000$

5. Cost of producing handouts on church planting ministry and other resources $=\mathrm{N} 500,000$

6. Miscellaneous expenses $=\mathrm{N} 200,000$

7. Total annual budget for the church planting ministry $=N 4,049,000$ or $\$ 26,993.33$

A means for income to meet the estimated budget expenses of the church-planting work will be embarked upon. First, appropriation from the two conferences will supplement the budget. This will come from the yearly budget for evangelism. Secondly, the North-east Nigeria Conference Treasurers Report at the Triennial Session $(2009$, p. 5) shows the following donors for church planting and building activities. These individuals would be consulted for financial assistance for church planting team. These were: Elder J.G. Buba donation of N4.8M, Chief Adi donated his school in addition to 4 plots of landed property, Prof. B.M. Mandong donated a personage in his home town, and 
A.G.Mavalla donated the sum of N1.6M for the 'Other Sheep Outreach;' Barrister L.T.C.Eruba donated seven class rooms, Prof. Benjamin Olufemi purchased a landed próperty for church building at Mubi at the sum of N250,000, and Elder Emmanuel Ogbonna sponsors one pioneer yearly with a stipend of N84,000; Spring Time Development Foundation donated the sum of N1.35M for Secretariat/church buildings, Borge Schantz and Co. donated the sum of N13.7M for three church building projects plus 74 sets of SDA Bible Commentaries, and NWNUM, WAD/ GC donation of N1.9 stipends for hiring 14 Global Mission Pioneers. Suffice it to say that the two Conferences have a total of 45 districts. And in each of the districts at least one donor would be sought for in addition to the ones enumerated above.

Table 3 below shows the total budget for the three training sessions as outlined above:

Table 3

Budgetary Income Planting Project

Appropriation from two conferences $\quad \mathrm{N} 1,000,000$ or $\$ 6,666.7$

Income from individual spônsors (50 with $\quad \mathrm{N} 2,500,000$ or $\$ 16,666.7$ an average donation of 50,000$)$

Income to be generated through general $\mathrm{N} 830,000$ or $\$ 5,533.3$ promotion 
Development of Relationship with Community Leaders

The business of the church is always ministry. Community leaders are hard to reach. These influential individuals are much less likely to show up at Revelation Seminars. Nonetheless, Sahlin (2004, p. 99) suggests ways to reach out to community leaders and develop personal relationships. This material is adaptable to the situation in Northern Nigeria. This would be utilized for the implementation of this project at its completion. These would be utilized for the implementation of this project at its completion.

\section{Information to the Community}

As we interview community leaders or have other contact with them, we will at least place in their hands a simple fact sheet and some attractive publication about our church. This packet will include both local and international information. I will advice my team for the use of "Facts about SDA church and "Who are the Seventh-day Adventists" leaflets. We will translate these to Hausa, the most spoken indigenous language in Northern Nigeria. We will be careful in the selection of materials to give community leaders in order to avoid insulting anyone by overtly recruiting them as members of our church during the first contact.

\section{Invitation to Community Leaders}

We will intentionally invite community leaders to speak at church during special occasions, for example, when presenting a Community Service Award to some volunteer who has done exemplary work. It may not be appropriate for them to be the preacher on Sabbath. We will just develop special opportunities. Community leaders are often willing to make short "remarks" on ceremonial occasions. Alternatively, we may plan to present 
the Community Service Award to a community leader to honor them for specific accomplishments, which our church wants to encourage; for example, when they provide night "vigilantes" to provide protection.

\section{Issues that Are Important}

We could also invite the community leaders to speak on issues that are important to them at special events related to those issues. For example, at a "Health Sabbath" event we could invite an appropriate leader to address an issue such as protecting the drinking water in the community or control of teen smoking or parental care of our children. The pastor may also preach, providing some basic reasons from the Bible why believers should be concerned about their health and that of their neighbors. In this special event, Bible principles and a contemporary concern come together. This is the kind of event to which many non-members could be invited to get an introductory view of Adventist faith.

\section{Series for Community Leaders}

We have the option of organizing a forum series to introduce our church members to the needs in the community and to introduce community leaders to our congregation. Each forum would allow one; two or three community leaders to discuss a particular area of need and tell how the church can help with this need. This will provide a good overall introduction that would both help our congregation understand the community and introduce it to a number of community leaders as a group interested in helping the community. 


\section{Meeting with Small Groups}

Another approach we may apply is to invite community leaders to come and meet with a small group such as our community outreach committee or a task force that is to develop specific program. Each leader who meets with the group would be invited to first give a talk on what they think about the needs and issues in the community. Then, the group would enter into dialogue with the individual, asking questions etc. This will be a good way to educate our group meet influential leaders, get into issues, and understand how others deal with those issues.

It is important to the mission of the church to identify and understand the influential leaders in our community. I believe they need our labor in the love and fear of God in order to get Christian principles on the agenda.

My plan is to begin this series January 2014 after interviewing community leaders so that, based on the interview we can invite the leaders who seem most interesting or relevant to the topics the congregation or group is also interesting in. We will try to know something about the community and its needs before venturing into the series of meetings.

\section{Summary}

This chapter has examined the historical background of the Seventh-day Adventist work in Northern Nigeria. While other Christian missionaries came to Nigeria as far back as the sixteenth century, it was not until 300 years later that the Adventist missionaries arrived. As late-comers, the Adventist Mission faced enormous difficulties before it secured a site to establish and develop its work in Northern Nigeria. 
However, we have discovered that, even in the midst of these difficulties, the Seventh-day Adventist Church has developed slowly but steadily in two local conferences in Northern Nigeria with nearly 165 organized churches having about 40,000 memberships today. The two conferences have altogether 70 ordained ministers, 20 unordained, and about 60 Global Pioneers.

It is worth noting that, in spite of frequent religious crisis in Northern Nigeria, the Seventh-day Adventist work has had a steady growth. Most of the work has been through public evangelism, which is offensive and in most cases forbidden and restricted. A mission strategy for Muslim evangelism has been designed accordingly. The researcher has discovered, through the review of literature and theological foundations for church planting, new methods that could be useful in reaching Muslims in Northern Nigeria. Among these are friendship, giving hospitality, considering felt needs, "Storying" and prayer. 


\section{CHAPTER 5}

\section{SUMMARY, CONCLUSION, AND RECOMMENDATIONS}

\section{Summary}

According to the missionary mandate, we are to "make disciples of all nations" (Matt 22:19), which includes all people groups in the world. The New Testament proves that the most effective discipline method is planting new congregations. The term, 'church planting' refers to a method used to fulfill the Great Commission. In reference to the church the Lord Jesus said, "Upon this rock I will build my church; and the gate of hell shall not prevail against it." (Matt16:18). The Apostle Paul used the terms build and plant interchangeably referring to those laboring in the city of Corinth, "I have planted and Apollos watered; but God gave increase." (1Cor.3:6)

It is evidenced that the disciples and apostles of Christ made church planting their strategy to penetrate first-century society. Christ said, "But you will receive power when the Holy Spirit comes on you; and you will be my witnesses in Jerusalem and in all Judea and Samaria and to the ends of the earth" (Acts 1:8). This mandate shows that the focus of church planting must be both local and global.

The purpose of this project is to develop a strategy for church planting in Northern Nigeria which is mostly dominated by Islam. The effort will help create a culture in the North-east and North-west-Nigeria Conferences of Seventh-day Adventists for planting new Adventist churches which are both biblically faithful and culturally 
relevant. This project also aims at encouraging prospective church planters in Northern Nigeria to commit their lives to rising up new churches that will reap a great harvest of souls for the kingdom of God.

\section{Reasons for Planting Churches}

1. Jesus recommended it (Matt 28:19-20)

2. It is a New Testament norm. Church planting is the New Testament way of spreading the gospel. The Disciples of Christ practiced it.

3. It is efficient. Wagner (1990, p. 11) observes that the single most effective evangelistic method under heaven is planting new churches. Growth of the new cells is faster and healthier than of the older body. New churches thrive with life.

4. It is natural. The biblical account of creation establishes a principle of reproduction 'according to their kind' (Gen.1:12) both for vegetation and for animal. Apple seeds beget apple trees, and sheep beget sheep.

5. It is necessary for denominational survival and growth. It enables the church planter to reach a growing population and to meet the changing needs of people.

6. It develops people. New missions help to accommodate church leaders looking for new challenges, and increase room for potential leaders to grow.

7. It brings renewal and stimulation into existing churches. It creates enthusiasm in the mother church, motivates them, and helps to cultivate missionary spirit and eliminate selfishness.

\section{Strategies for Church Planting}

From the literature reviewed in chapter three, Dudley and Gruesbeck (1989, pp. 50-63) suggest five strategies for increased growth in the area of church planting: 
Strategy one-educate for awareness. Develop a team of educators to conduct seminars in strategic locations throughout a union conference territory.

Strategy two-communicates the progress of the new congregation. The constituency should be kept informed on the progress of new congregations and exciting events taking place in new groups. This is because it is most evidence today that most people want to participate in decision-making process.

Strategy three-new congregations in the cities: In large cities without a congregation, leaders need to lay definite plans for re-entering the cities and adding even multiplying -new congregations because the church can reach more people and grow faster by planting churches there.

Strategy four-large congregations become parents. Another approach the church can take to reach out to millions is to encourage every church with over 400 members to plant a church every two years. This is because many members of large churches have lost their vision and concern for lost people.

Strategy five-planting by Transplanting. In this church planting model people are moved into an area for the purpose of sharing Good News. As Jesus mingled among the people of His day, we need to mingle among the city dwellers and tell them about a loving, caring Savior who wants to become the Lord of their lives. (pp. 50-63)

\section{Reaching the Muslims in Northern Nigeria}

Islam has a very basic doctrine, namely, that although Jesus and Christians have received revelations from God, they have not preserved these faithfully. As a result, God had to issue this revelation through Muhammad and the Qur'an. Although Jesus and Christians are tolerated in Muslim societies as people of the book, their faiths are corrupted versions of the faith God has corrected in Islam.

Given this basic understanding in Islamic thought, the overwhelming majority of Muslims see Christianity the way most Christians through most of Christian history have seen Judaism as a religion that has been superseded. This explains Muslims notorious resistance to conversion to Christianity. As most Christians do not find any appeal in an invitation to convert to Judaism because it seems like a step backward historically and religiously, so Muslims are repulsed by any invitation to convert to Christianity. 
However, through the literature reviewed in chapter three we discovered that critical contextualization and friendship evangelism will be appropriate for our Muslim friends in Northern Nigeria.

\section{Conclusion}

The church is not a man-made organization created to oppress and control the people of the world. Rather, it is Christ-commissioned organism created to be an extension of the work of Jesus Christ. The reason for the establishment of the church is to offer salvation, wholeness, healing and transformation to a sin-sick world. It is to reach out to the world with the truth and reality of the gospel.

Church planting therefore is the means for expressing God's mission, a key strategy fulfilling Jesus' Great Commission. It is an avenue for making disciples and necessary for the transformation of cultures and societies. Although church planting is not without obstacles, we are called to give it a serious consideration because it is divinely ordained. It is an act of God.

In view of this, divine wisdom and human cooperation is required of us in our effort in planting churches among the Muslims in Northern Nigeria. Genuine friendship is the most important condition for establishing a good and amiable relationship with our Muslim friends. Opportunities for friendship evangelism are available in Northern Nigeria where both Christians and Muslims, and even Animists mingle and interact. We meet with Muslims in Northern Nigeria in market places, factories or schools, in business offices or social gatherings. Sometimes they can be neighbors, fellow workers, business contacts, and fellow students. 
An observant Christian will find or even create opportunities. It can be done by sharing hospitality, friendliness, and helpfulness even by asking a favor. It can happen in the most unexpected places. Fruitful contacts with Muslims who want to know more about Christ occurs as a natural thing as one goes about his or her daily activities.

\section{Recommendations}

"Go ye therefore and make disciples of all the nations, baptizing them in the name of the Father and of the Son and of the Holy Spirit, teaching them to observe all things that I have commanded you ; and lo, I am with you always, even to the end of the earth." Amen (Matt 28:19-20). Muslims in Northern Nigeria are part of the nations that are still waiting to be reached with the gospel of salvation.

Islam is expanding rapidly in Northern Nigeria like in other parts of the globe. This poses a big challenge to the Christian Church at large and especially to the Seventhday Adventist church which has the mandate to preach the everlasting gospel. Based on the theological foundations and literature reviewed on church planting in general and among the Muslims in particular, I have the following recommendations to offer for future church planting endeavors:

1. The General Conference of Seventh-day Adventist church should not withdraw the funding of the 10/40 Window it has embarked upon. Such funds should not be misappropriated; it should be used for the training and up keeping of Global Mission Pioneers. Parts of the funds could be used for purchasing Bibles and appropriate literature for Muslim evangelism.

2. Since there is high illiteracy rate among our Muslim friends in Northern Nigeria, the production of audio New Testament tapes in Arabic and Hausa should be considered 
through the combined effort of the two Conferences in the north of Nigeria, the Northwestern Nigeria Union and the West-central Africa Division of the SDA church.

3. The GC should, in their yearly budget, set aside sufficient funds for the Westcentral Africa Division's department of Adventist Muslim Relation. This will provide opportunities for effective planning of its programs and enhance activities in the 10/40 Window. This will also help in rehabilitating and giving better nurture to new converts from Islam.

4. The Adventist World Radio programs have had great impact in Northern Nigeria. As such, special attention should be given to the AWR in reaching our Muslim friends and communities. Information about transmission frequencies should be made available through the laity to their Muslim friends and neighbors.

5. The study of Islam should be encouraged in the Seventh-day Adventist Theological Institutions within the West-central Africa Division. Several contextual methods for friendship evangelism with Muslims should be included in their mission curriculum. A diploma in Islam could also be offered with an Arabic emphasis.

6. Considering the sensitivity of Islam and Muslims in Northern Nigeria, the laity should be trained on how to conduct friendship evangelism with the Muslims. This basic training will help them in overcoming their fear in witnessing to Muslims.

7. The department of Adventist Muslim Relationship should encourage church leaders of the urgent need to establish strong relationships with the Imams. Such relationships may help to avoid misunderstanding when Muslims are converted to Christianity. A yearly interfaith dialogue could be carefully organized. 
8. Church leaders in the two Seventh-day Adventist Conferences of Northern Nigeria should be opened to accepting new approaches to mission and ministry since public evangelism in the past years have not yielded much.

9. Church members should be encouraged to be faithful stewards. Member's faithfulness in the use of their means will help a great deal in supporting a contextual approach to Muslim evangelism from the beginning of the year 2013.

10. Realizing the sensitive nature of Muslim communities in Northern Nigeria, the Global Mission Pioneers must be trained for Muslim outreach. In place of public preaching, friendship evangelism should be introduced. 
APPENDIX A

MISSION AND CONFERENCE STATISTICS

NORTH NIGERIA MISSION ORGANIZED CHURCHES (1948-1993) 


\section{MISSION AND CONFERENCE STATISTICS}

NORTH NIGERIA MISSION ORGANIZED CHURCHES (1948-1993)

North Nigeria Mission Organized Churches 1948-1993

\begin{tabular}{|c|c|c|c|c|}
\hline$\underline{\mathrm{S} / \mathrm{N}}$ & & Church & District & Date organized \\
\hline 1 & & Amo Bisa & Katako & 1947 \\
\hline 2 & & Durmi & Doka & 1953 \\
\hline 3 & & Babban Fadama & Doka & August, 1956 \\
\hline 4 & & Kawam & Katako & 1958 \\
\hline 5 & & Arum Tumara & Wamba & March 18, 1967 \\
\hline 6 & & Warsa & Warsa & Dec. 12,1970 \\
\hline 7 & & Kalambai & Jengre & 1973 \\
\hline 8 & $i$ & Lishin & Katako & Dec. 1973 \\
\hline 9 & & Kakunka & Jengre & 1974 \\
\hline 10 & & Padaman Shanu & Jengre & March, 1975 \\
\hline 11 & . & Saminaka & Saminaka & Sept. 9, 1978 \\
\hline 12 & & Massenge & Wamba & April 25, 1981 \\
\hline 13 & & Zaria & Kaduna & May 15,1981 \\
\hline 14 & & Tsohon Yadi & Doka & Dec. 11,1982 \\
\hline 15 & & Amere & Kafanchan & May 8,1982 \\
\hline 16 & & Gombe & Gombe & Oct. 30,1982 \\
\hline 17 & & Kono & Doka & Dec. 11,1982 \\
\hline 18 & & Maiduguri & Maiduguri & March 17, 1984 \\
\hline 19 & & Matsira & Jengre & April 28, 1984 \\
\hline 20 & & Katako & Katako & May 5,1984 \\
\hline 21 & & Rimi & Kantau & June 2, 1984 \\
\hline 22 & & Kyere & Saminaka & Feb. 2, 1985 \\
\hline 23 & & Ganji & Saminaka & May 18,1985 \\
\hline 24 & & Kurmin-Dodo & Warsa & Nov. 16,1985 \\
\hline 25 & & Pambeguwa & Pambeguwa & April 5, 1986 \\
\hline 26 & & Kuzamani & Ramin Kura & April 19, 1986 \\
\hline
\end{tabular}


Kantau

Kantau

Oct.11, 1986

Mista-ali

Jos

April 18, 1987

29

30

Ramin Kura

Ramin Kura

May 9, 1987

31

Nasarawa

Kayarda

Oct. 31, 1987

32

Zarkwai

Warsa

April 9, 1988

33

Majaja

Katako

Feb.18, 1989

Anguwan Makama

Kaduna

March 25, 1989

35

36

37

38

39

40

41

42

43

44

45

46

Kayarda

Abuja

Kantau

Katako

Saminaka

Saminaka

Zaria

Pambeguwa

Jengre

Jos

Abuja

Gombe

Warsa
Jan.13, 1990

Sept.14, 1991

Nov.9, 1991

Nov.16, 1991

Jan.25, 1992

Feb.22, 1992

March 14, 1992

March 21, 1992

March 28, 1992

April 11, 1992

April 11, 1992

July 18, 1992

Oct. 31, 1992 
NORTH-EAST NIGERIA CONFERENCE ORGANIZED CHURCHES (1993-2008) North-east Nigeria Conference Organized Churches (1994-2009)

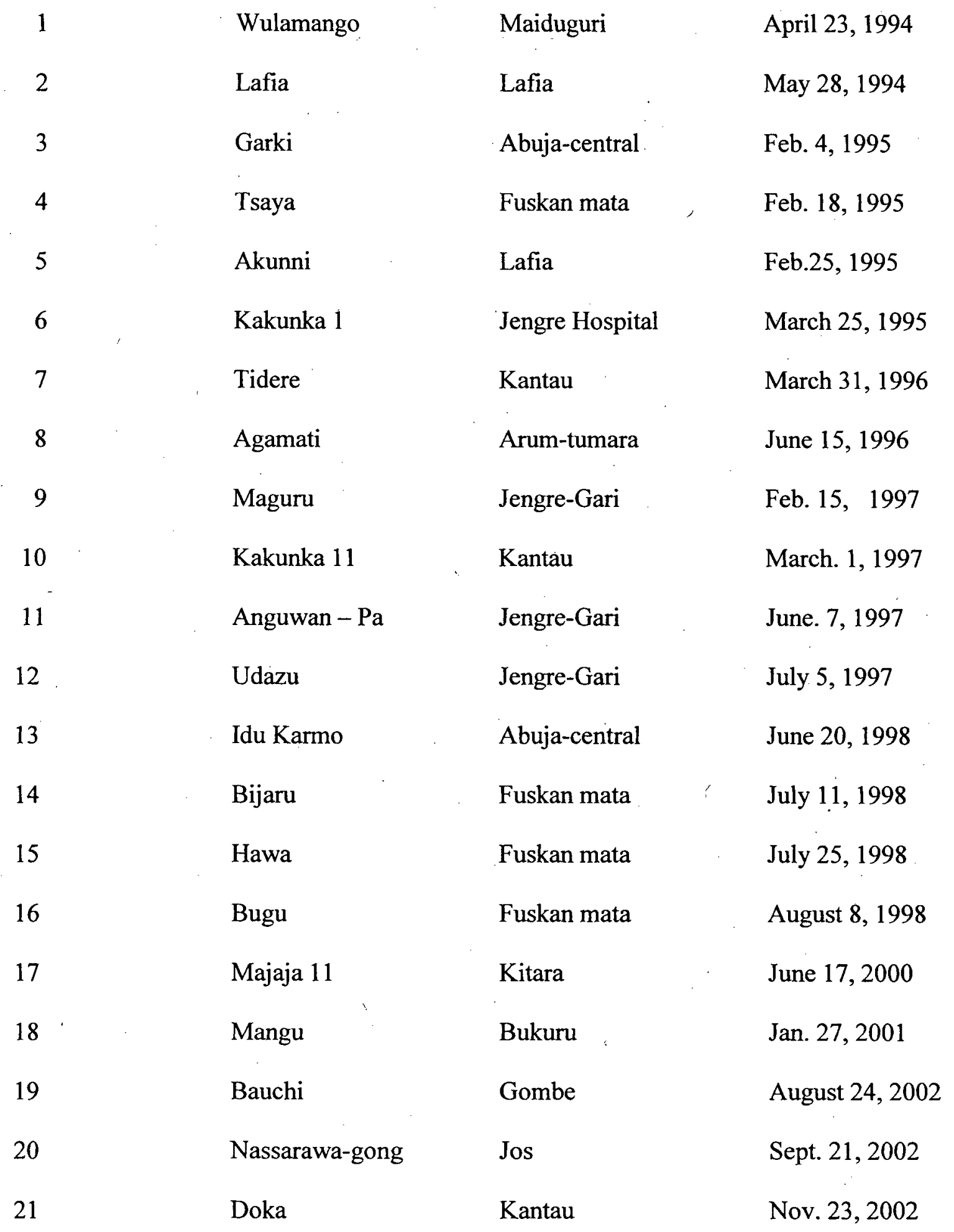


Nov. 22, 2003

Doka

Rimi

Nov. 29, 2003

24

25

Lugbe

Abuja-central

June 11, 2004

.

26

Pindau

Jengre Gari

April 3, 2004

Fichiza

Kides

April 24, 2004

27

Farin Gada

Laranto

March 6, 2004

28

Tsika

Fuskan mata

March 8, 2005

29

30

Gawu

Laranto

Jan. 8, 2006

Kuduru

Abuja-west

May 5, 2007

31

32

33

34

Tudun Wada

Jos

May 22, 2007

Gada Biu

Jos

June 2, 2007

Ulani

Kides

May 15, 2007

Dangara

Laranto

Feb. 17, 2007

35

Kwali

Abuja-central

August 30, 2008

36

Jalingo

Yola

August 30, 2008

37

Arum-Tsavo

Arum Tumara

Sept. 20, 2008

38

Aso-pada

Nyanya

Dec.20, 2008 
NORTH-EAST NIGERIA CONFERENCE STATISTICS (1993-2008)

North East Nigeria Mission and Conference Statistics (1993-2008)

\begin{tabular}{lrrrrrrrrr}
\hline Year & 1993 & 1994 & 1995 & 1996 & 1997 & 1998 & 1999 & 2000 & 2001 \\
\hline Church & 34 & 36 & 42 & 45 & 49 & 53 & 53 & 55 & 55 \\
Companies & & & & & 56 & 60 & 99 & 99 & 99 \\
Beginning & & & & & 1056 & 1141 & 1219 & 1478 & 1591 \\
Membership & 7281 & 8299 & 9234 & 9692 & 8 & 3 & 6 & 1 & 2 \\
Baptisms & 1011 & 872 & 498 & 893 & 908 & 805 & 2613 & 1000 & 606 \\
$\begin{array}{l}\text { Professions } \\
\text { of Faith }\end{array}$ & & & & & & & & & \\
Transfer In & 131 & 196 & 38 & 133 & 66 & 136 & 107 & 146 & 122 \\
Transfer Out & 55 & 87 & 61 & 99 & 51 & 114 & 99 & 39 & 97 \\
Deaths & 21 & 24 & 7 & 15 & 20 & 22 & 25 & 17 & 35 \\
$\begin{array}{l}\text { Dropped } \\
\text { Missing }\end{array}$ & 48 & 22 & 10 & 36 & 58 & 40 & 53 & 0 & 0 \\
Ending & & & & & & & 0 & 0 & 0 \\
Membership & 8299 & 9234 & 9692 & 8 & 3 & 6 & 1 & 2 & 4 \\
$\begin{array}{l}\text { Ordained } \\
\text { Ministers }\end{array}$ & 11 & 13 & 14 & 14 & 14 & 12 & 19 & 19 & 17 \\
Licensed & & & & & & & & & \\
Ministers & 14 & 10 & 8 & 16 & 18 & 21 & 13 & 13 & 16 \\
\hline
\end{tabular}

\begin{tabular}{lrrrrrrr}
\hline Year & 2002 & 2003 & 2004 & 2005 & 2006 & 2007 & 2008 \\
\hline Church & 58 & 59 & 72 & 72 & 72 & 72 & 80 \\
Companies & 94 & 87 & 78 & 78 & 83 & 85 & 89 \\
Beginning & & & & & & & \\
Membership & 16534 & 17390 & 18322 & 19756 & 20406 & 21106 & 22726 \\
Baptisms & 789 & 916 & 1222 & 685 & 824 & 1107 & 792 \\
Professions of Faith & 43 & 13 & 34 & 12 & 6 & 22 & 14 \\
Transfer In & 203 & 156 & 214 & 149 & 116 & 557 & 32 \\
Transfer Out & 119 & 90 & 124 & 157 & 90 & 52 & 25 \\
Deaths & 59 & 19 & 64 & 26 & 22 & 14 & 10 \\
Dropped & 1 & 44 & 3 & 13 & 134 & 0 & 5 \\
Missing & 0 & 0 & 0 & 0 & 0 & 0 & 0 \\
Ending & & & & & & & \\
Membership & 17390 & 18322 & 19601 & 20406 & 21106 & 22726 & 23524 \\
Ordained Ministers & 17 & 19 & 24 & 26 & 26 & 25 & 25 \\
Licensed Ministers & 19 & 18 & 15 & 15 & 16 & 15 & 14 \\
\hline
\end{tabular}


NORTH-WEST NIGERIA CONFERENCE ORGANIZED CHURCHES (1993-2008) North-west Nigeria Conference Organized Churches (1993-2008)

\begin{tabular}{|c|c|c|c|}
\hline$\underline{\mathrm{S} / \mathrm{N}}$ & Church & District & Date Organized \\
\hline 1 & Pasakori & Kafanchan & March 5, 1994 \\
\hline 2 & Ugwan Dungu & Pambeguwa & April 9, 1994 \\
\hline 3 & Kayarda & Kayarda & June 11, 1994 \\
\hline 4 & Gadako & Kayarda & July 16,1994 \\
\hline 5 & Samaru & Zaria & July 23, 1994 \\
\hline 6 & Mararraban Lazuru & Saminaka & August 6, 1994 \\
\hline 7 & Dan Alhaji & Tsohon Yadi & Oct. 11,199 \\
\hline 8 & West Ogbomosho & Kaduna & Nov. 5, 1994 \\
\hline 9 & Minna & Minna & Nov. 12, 1994 \\
\hline 10 & Gaja gaja & Maigamo & March 11, 1994 \\
\hline 11 & Kadawa & Maigamo & March 25, 1995 \\
\hline 12 & Abadawa 1 & Saminaka & March 25, 1995 \\
\hline 13 & Abadawa 11 & Saminaka & April 8, 1995 \\
\hline 14 & Anguwan Bawa & Saminaka & April 29, 1995 \\
\hline 15 & Tudun Amawa & Pambeguwa & May 20,1995 \\
\hline 16 & Kabudu & Kono & March 16, 1996 \\
\hline 17 & Rafin Gora & Ramin Kura & April 25, 1996 \\
\hline 18 & Kadere & Garun Kurama & March 8, 1997 \\
\hline 19 & Kadage & Kauru & April 18, 1998 \\
\hline 20 & Kadiri 11 & Ramin Kura & April 25, 1998 \\
\hline 21 & Zakada & Pambeguwa & May 9,1998 \\
\hline
\end{tabular}


Kauru

May 23, 1998

23

Mariri

Damakasuwa

Jan. 30, 1999

24

Bima

Damakasuwa

Feb. 13, 1999

25

Makeni

Kano

May 16, 2001

26

Maji-Bakwai

Warsa

June 2, 2001

27

Kauran Dawa

Warsa

June 9, 2001

28

Binawan Kazoh

Warsa

June 23, 2001

29

Sabon Fili B.

Ganji

March 2, 2002

30

Marma B.

Ganji

June 11, 2002

31

Anguwan Yelwa

Kaduna

Oct. 5, 2002

32

Dogon Fili

Kafanchan

April 3, 2004

33

Kagadama

Pambeguwa

April 24, 2004

34

Kagoma

Ganji

April 19, 2008

35

Anawan Fuloti

Warsa

April 252009

36

Romi

Yelwa

July 25,2009 
NORTH-WEST NIGERIA CONFERENCE STATISTICS (1993-2008)

North West Nigeria Mission and Conference Statistics (1993-2008)

\begin{tabular}{|c|c|c|c|c|c|c|c|c|}
\hline Year & 1994 & 1995 & 1996 & 1997 & 1998 & 1999 & 2000 & 2001 \\
\hline Churches & 41 & 51 & 52 & 54 & 57 & 59 & 59 & 63 \\
\hline Companies & & & & 99 & 95 & 93 & 93 & 89 \\
\hline \multicolumn{9}{|l|}{ Beginning } \\
\hline Membership & 6939 & 7498 & 8198 & 8916 & 10315 & 10619 & 12550 & 12996 \\
\hline Baptisms & 597 & 738 & 776 & 996 & 781 & 1914 & 595 & 646 \\
\hline \multicolumn{2}{|l|}{ Professions of Faith } & & & & 30 & 66 & 13 & 29 \\
\hline Transfer In & 601 & 47 & 61 & 52 & 59 & 70 & 73 & 137 \\
\hline Transfer Out & 577 & 53 & 72 & 66 & 53 & 70 & 94 & 119 \\
\hline Deaths & 18 & 9 & 25 & 18 & 27 & 28 & 57 & 51 \\
\hline Dropped & 44 & 23 & 22 & 23 & 28 & 21 & 84 & 36 \\
\hline Missing & & & & & & 0 & 0 & 0 \\
\hline \multicolumn{9}{|l|}{ Ending } \\
\hline Membership & 7498 & 8198 & 8916 & 10315 & 10619 & 12550 & 12996 & 13602 \\
\hline Ordained & & & & & & & & \\
\hline Ministers & 12 & 15 & 14 & 14 & 15 & 14 & 14 & 18 \\
\hline \multicolumn{9}{|l|}{ Licensed } \\
\hline Ministers & 14 & 14 & 13 & 15 & 10 & 13 & 13 & 6 \\
\hline Year & 2002 & 2003 & 2004 & 2005 & 2006 & 2007 & 2008 & \\
\hline Churches & 66 & 66 & 69 & 72 & 72 & 73 & 74 & \\
\hline Companies & 144 & 147 & 147 & 137 & 137 & 156 & 174 & \\
\hline \multicolumn{9}{|l|}{ Beginning } \\
\hline Membership & 13602 & 14172 & 14657 & 15172 & 15525 & 16339 & 16576 & \\
\hline Baptisms & 604 & 578 & 761 & 626 & 926 & 771 & 755 & \\
\hline Professions of Faith & 38 & 22 & 24 & 36 & 36 & 25 & 33 & \\
\hline Transfer In & 130 & 144 & 110 & 102 & 92 & 134 & 108 & \\
\hline Transfer Out & 99 & 127 & 216 & 220 & 147 & 262 & 261 & \\
\hline Deaths & 50 & 49 & 44 & 82 & 43 & 61 & 50 & \\
\hline Dropped & 48 & 81 & 42 & 103 & 45 & 81 & 114 & \\
\hline Missing & 0 & 2 & 3 & 6 & 5 & 254 & 7 & \\
\hline \multicolumn{9}{|l|}{ Ending } \\
\hline Membership & 14172 & 14657 & 15097 & 15525 & 16339 & 16576 & 17786 & \\
\hline Ordained Ministers & 18 & 18 & 19 & 19 & 19 & 17 & 17 & \\
\hline Licensed Ministers & 13 & 10 & 13 & 13 & 17 & 13 & 21 & \\
\hline
\end{tabular}


APPENDIX B

INTERVIEW QUESTIONS 


\section{INTERVIEW QUESTIONS \\ PUT TO CHURCH PLANTERS IN MUSLIM CITIES}

The goal of this interview is to delineate some of the contributing factors that led to the establishment of existing Muslim convert congregations in your area. It is a research interview questionnaire aimed at investigating your involvement in Muslim evangelism in Northern Nigeria. Your contribution will be highly appreciated. Please note that your name is not required; be rest assured that confidentiality is guaranteed.

Researcher: Daria, Francis Freeman

Research Title: A strategy for church planting in Northern Nigeria beginning in ZangonKataf

1. How long and how often have these former Muslims associated as a group?

2. What do you believe are the primary reasons they come to these meetings? (What felt needs are being met?)

3. Which ones come of their personal initiative and who is coming because of the authority of another?

4. How are decisions to attend such a meeting made?

5. What do those attending perceive their relationship to be to one another? How would you compare it to their loyalty or commitment to blood relatives?

6. To what degree have those attending had to resist opposition to come to these meetings?

7. Are there levels of belonging or acceptance in the group with which you are working, for example, members vs. observers? 
8. What is required to become a fully integrated "member"?

9. How would you describe the turnover rate?

10. To what would you attribute the turnover?. What factors contribute to absenteeism?

11. What felt needs would motivate a person to stop identifying with the group?

12. Where fear is perceived as being a major factor in preventing a believer from congregating with the group, what do you ascertain are the primary fears?

13. What would it take on a human level to see a cluster of congregations of former Muslims become a reality in Northern Nigeria?

14. What theory or applications do you feel must be applied by the existing change agents in this location?

15. What do you think is the most effective activity being practiced by church planters among Muslims anywhere? 


\section{APPENDIX C}

TRAINING SESSION FOR 28 GLOBAL MISSION PIONEERS 
TRAINING SESSION FOR 28 GLOBAL MISSION PIONEERS

(FEBRUARY 2013)

Instructor: Daria, Francis Freeman

Venue: SDA Hospital church Jengre

Duration: Seven days

\begin{tabular}{|c|c|c|}
\hline Sunday & $10 \mathrm{am}-12: 30 \mathrm{pm}$ & Arrival \& registration \\
\hline & $1: 45-2: 45 \mathrm{pm}$ & Welcome \& devotion \\
\hline & $3-3: 45 \mathrm{pm}$ & The Great commission \\
\hline & 4-4:45 PM & Missions in Muslim lands \\
\hline & $5-5: 30 \mathrm{pm}$ & Questions \& answers session \\
\hline & & . \\
\hline Monday & $6-7$ am & Wash up \\
\hline & $7-8$ am & Breakfast \\
\hline & $8: 15-8: 45$ am & Devotion \\
\hline & $9-10$ am & Muslims, who are they $\&$ where do they come from? \\
\hline & $10: 15-11 \mathrm{am}$ & Brief Islamic history \\
\hline & $11: 15-12: 15$ am & Main Islamic beliefs \\
\hline & $12: 15-1: 45 \mathrm{pm}$ & Lunch \\
\hline & $1: 45-2: 45 \mathrm{pm}$ & $\begin{array}{l}\text { Specific Muslim doctrines: Allah, the Supreme } \\
\quad: \\
\text { Being, Isa (Jesus Christ) }\end{array}$ \\
\hline
\end{tabular}


3-3:45 pm

$4-4: 45 \mathrm{pm}$

$5-5: 30 \mathrm{pm}$

Tuesday 6-7. am

7-8 am

8-8:45 am

9-10 am

10:15-11 am

$11: 15-12: 15 \mathrm{pm}$
Specific Muslim doctrines: The Qur'an; Sin; the concept of salvation

Muslims resistance to Christianity

Question \& answers session

Wash up

Breakfast

Devotion

Different kinds of Muslims

Muslims' attitudes to life

Five pillars of faith: (1) Confession of faith, (2)

Ritual prayers

$\begin{array}{ll}12: 15-1: 45 \mathrm{pm} & \text { Lunch } \\ \text { 1:45-2:45 pm } & \text { Five pillars (3) Social taxation, (4) The fast, } \\ \text { 3-3:45 pm } & \text { Five pillars (5) Pilgrimage; Jihad the.holy war } \\ \text { 4-4:45 pm } & \text { Introduction (the six articles of faith) } \\ 5-5: 30 \mathrm{pm} & \text { Question \& answer session }\end{array}$

Wednesday $\quad$ 6-7 am

Wash up

7-8 am

Breakfast

8- 8:45 am

Devotion

9-10 am

Article (1) Doctrines of Allah (2) Doctrines of angels

10:15-11 am

Article (3) Revealed Scriptures (4) the Messenger of

Allah 
$11: 15-12: 15 \mathrm{pm}$

$12: 15-1: 45 \mathrm{pm}$

$1: 45-2: 45 \mathrm{pm}$

3-3:45 pm

4-5 pm

$5-5: 30 \mathrm{pm}$
Article (5) Last day events \& Day of Judgment (6)

Predestination

Lunch

Muslim Evangelism

Personal Evangelism

Lessons from life \& experience (1) Friendship, (2)

Hospitality

Question \& answer session

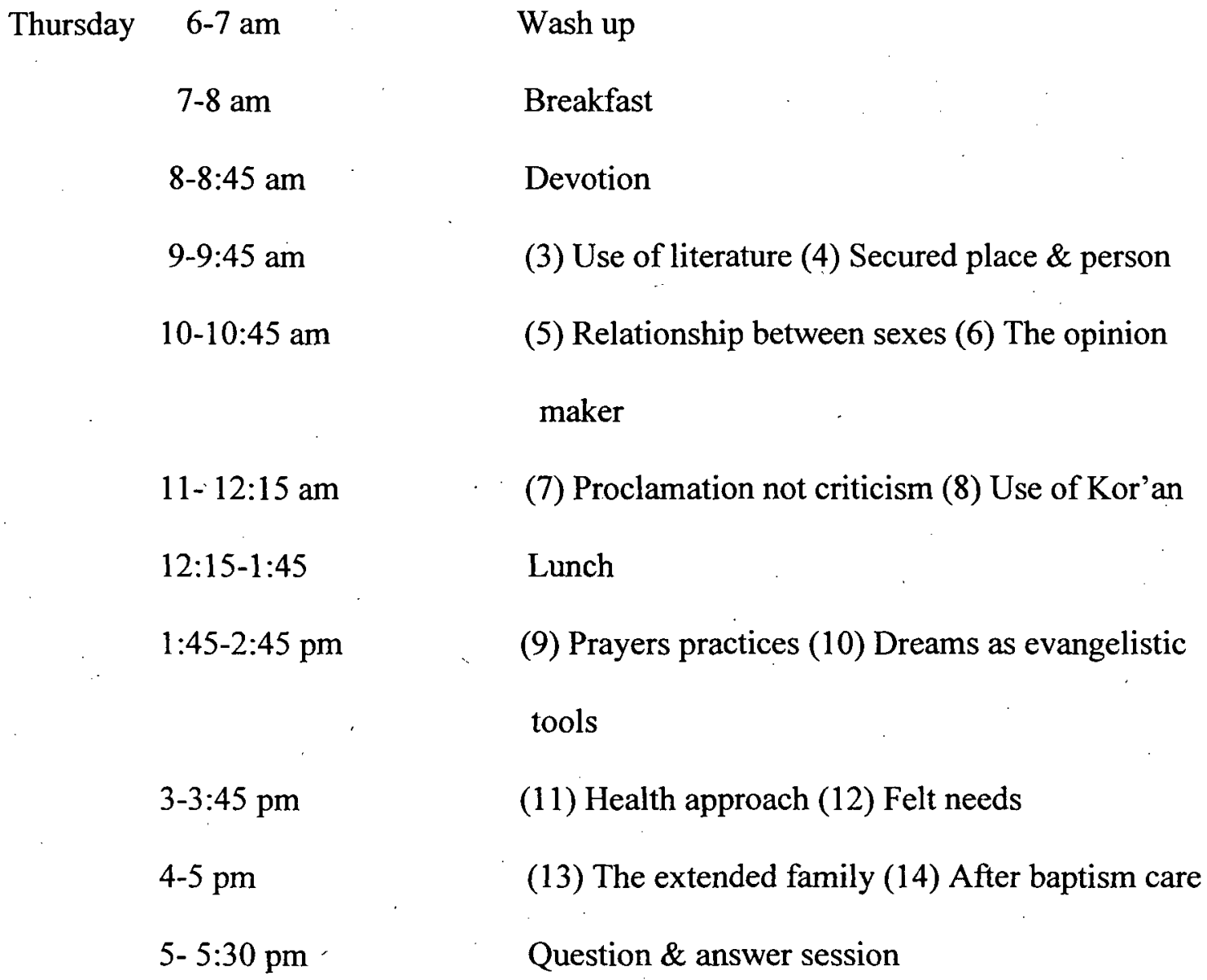




$\begin{array}{ll}\text { Friday } & 6-7 \mathrm{am} \\ 7-8 \mathrm{am} & \text { Wash up } \\ 8-8: 45 \mathrm{am} & \text { Breakfast } \\ 9-9: 45 \mathrm{am} & \text { Devotion } \\ 10-10: 45 \mathrm{am} & \text { The Muslim's lifestyle } \\ 11-11: 45 \mathrm{am} & \text { Childhood, youth \& circumcision } \\ & \text { Marriage, the role of women in Islam, dress of } \\ 12-1 \mathrm{pm} & \text { Muslim women } \\ 1-6 \mathrm{pm} & \text { Divorce, birth control and inheritance } \\ 7-8 \mathrm{pm} & \text { Lunch \& Sabbath preparation } \\ & \text { VESPERS SERVICE }\end{array}$

Saturday 9-11 am

Sabbath School

$11-12: 30$

Divine Worship (Sermon title, "Sooner than you think")

$12: 30-2: 45 \mathrm{pm}$

Lunch \& rest

3-4 pm

Adventist-Muslim Fundảmental Beliefs

4-5 pm

Official statement on Islam by SDA to provide

"Relationship Tools"

$5-6 \mathrm{pm}$

Question \& answer session

$7-8 \mathrm{pm}$

Sundown worship \& closing exercise 
The Religious Worldviews of Adventism and Islam Compared

\begin{tabular}{|c|c|c|}
\hline $\begin{array}{l}\text { Adventist } \\
\text { Worldview }\end{array}$ & Muslim Worldview & Comparison \\
\hline $\begin{array}{l}\text { God has revealed } \\
\text { Himself in creation and } \\
\text { created works, in Scripture } \\
\text { through the Prophets, in } \\
\text { Jesus, and through the Holy } \\
\text { Spirit }\end{array}$ & $\begin{array}{l}\text { God the Creator has } \\
\text { sent messages of guidance } \\
\text { through His messengers } \\
\text { who wrote in the Torah, } \\
\text { Zaboor, and Injil. The final } \\
\text { revelation was given to } \\
\text { Muhammad in the Qur'an }\end{array}$ & $\begin{array}{l}\text { We agree on the } \\
\text { basic concept of the Creator } \\
\text { God sending messages } \\
\text { through the Prophets for the } \\
\text { guidance of His people. We } \\
\text { need to move the Muslims } \\
\text { to the more personal } \\
\text { concept of God revealing } \\
\text { himself. While respecting } \\
\text { Muhammad as a reformer } \\
\text { and the Qur'an as } \\
\text { containing some truth we } \\
\text { must move the basis of faith } \\
\text { to the Scriptures. }\end{array}$ \\
\hline $\begin{array}{l}\text { God is } \\
\text { "Superintendent" of history, } \\
\text { and is working out His } \\
\text { eternal purposes in the } \\
\text { "Great Controversy" } \\
\text { between good and evil. }\end{array}$ & $\begin{array}{l}\text { God, in His } \\
\text { transcendence, does as He } \\
\text { wills in history. There is a } \\
\text { battle between God and } \\
\text { Iblis (Satan), and Satan is } \\
\text { seeking to deceive as many } \\
\text { as possible, but God } \\
\text { provides protection and } \\
\text { guidance to the faithful. }\end{array}$ & $\begin{array}{l}\text { The key concepts } \\
\text { are similar including the } \\
\text { God--Satan controversy. } \\
\text { We can build on this to } \\
\text { introduce the "expanded" } \\
\text { understanding of the issues } \\
\text { in the Great Controversy } \\
\text { and how God is working } \\
\text { through a demonstration of } \\
\text { His character rather than } \\
\text { force. }\end{array}$ \\
\hline $\begin{array}{l}\text { God is the Creator of } \\
\text { all things, His creation of } \\
\text { the earth was perfect, but } \\
\text { was defiled by the fall of } \\
\text { man. }\end{array}$ & $\begin{array}{l}\text { God is the Creator } \\
\text { of all things, a perfect world } \\
\text { that was lost in the mistake } \\
\text { of Adam and Eve. }\end{array}$ & $\begin{array}{l}\text { God as Creator is } \\
\text { the same. The fall of man is } \\
\text { similar but the nature and } \\
\text { consequence of the fall is } \\
\text { not as severe in Islam. } \\
\text { Again we build on the } \\
\text { similarity to lead to an } \\
\text { understanding of the } \\
\text { seriousness of sin leading to } \\
\text { a state of brokenness. }\end{array}$ \\
\hline $\begin{array}{c}\text { God's work in } \\
\text { solving the sin problem in }\end{array}$ & $\begin{array}{c}\text { God solves the } \\
\text { problem of "misguidance" }\end{array}$ & $\begin{array}{c}\text { This entire } \\
\text { proposition contains }\end{array}$ \\
\hline
\end{tabular}




\begin{tabular}{|c|c|c|}
\hline $\begin{array}{l}\text { the universe, refuting the } \\
\text { accusations of the evil one, } \\
\text { becoming one with us, } \\
\text { sacrificing Himself in } \\
\text { human form, reconciling us } \\
\text { to Himself. Thus ensuring } \\
\text { the security of the universe } \\
\text { from sin through eternity, } \\
\text { securing full loyalty and } \\
\text { trust of His creation while } \\
\text { respecting the individual } \\
\text { freedom to either give or } \\
\text { withhold that loyalty. }\end{array}$ & $\begin{array}{l}\text { in His universe by ( } 1 \text { ) } \\
\text { forgiving the repentant and } \\
\text { submissive believer; and (2) } \\
\text { judging between one's good } \\
\text { and bad works on the day of } \\
\text { judgment. His judgment is } \\
\text { transcendent and final and } \\
\text { results in the faithful in } \\
\text { paradise and the unbelievers } \\
\text { in hell fire. }\end{array}$ & $\begin{array}{l}\text { perhaps the largest degree } \\
\text { of difference. The general } \\
\text { concept of forgiveness and } \\
\text { a day of judgment are } \\
\text { similar. However, the way } \\
\text { of forgiveness through God } \\
\text { reconciling man to Himself } \\
\text { by incarnating and then } \\
\text { sacrificing Himself must be } \\
\text { gradually taught. God's. } \\
\text { respect for the individual's } \\
\text { freedom of choice is news } \\
\text { to the Muslim. }\end{array}$ \\
\hline $\begin{array}{l}\text { The creation of a } \\
\text { new heaven and earth at the } \\
\text { end of time and the } \\
\text { beginning of an eternity of } \\
\text { righteousness. }\end{array}$ & $\begin{array}{l}\text { God will establish a } \\
\text { rule of righteousness and } \\
\text { cleanse the earth from } \\
\text { unbelief, ushering in an } \\
\text { eternity of righteousness. }\end{array}$ & $\begin{array}{l}\text { The general } \\
\text { concepts are quite similar. } \\
\text { The details of the } \\
\text { millennium and the final } \\
\text { end of sin vary. }\end{array}$ \\
\hline
\end{tabular}

Source: Adventist Responses to Cross-cultural Mission. Global Mission Issues

Committee Papers (2), 42-43 


\section{OFFICIAL STATEMENT ON ISLAM}

\section{BY THE SEVENTH-DAY ADVENTIST CHURCH (TRANS- EUROPEAN DIVISION) TO PROVIDE "REALATIONSHIP}

TOOL"

[March 28, 2007] As almost any psychologist will tell you, open-minded dialogue is vital to achieving mutual respect and understanding. That advice also applies to communities of faith, according to Seventh-day Adventist leaders in the church's TransEuropean (TED) region, where an estimated 60-65 percent of citizens are Muslims.

Adventists in the region recently adopted an official statement on Islam to help foster a more constructive relationship between Muslims and Christians. "As the [Adventist] movement continues to grow in the world," the statement begins. "We are looking for [a] good relationship with Islam, a faith with a similar sense of godly calling that is followed by one-fifth of the world's population.

The statement draws parallels between Islam and Christianity, such as submission to the Creator God and a common Abrahamic heritage. It also applauds the scientific, literary and philosophical contributions of Muslims throughout history and recognizes Islam's Prophet Muhammad as "a spiritual and social reformer at a time of confusion and ignorance."

"We believe that among peoples of all faith, God has, through history, preserved a people of authentic submission in the face of apostasy, oppression and persecution. We acknowledge that within Islam there are such people ... Within this group of sincere believers we see potential partners for further exploring our spiritual understanding of the One through God," the statement reads.

The Statement ends with a call for Adventists to commit to "honesty, fairness and respect in describing Islamic faith," and vice versa. It acknowledges doctrinal 
differences—-such as belief in Christ as Savior and Son of God—but says such differences should "not be made points of controversy or generate an attitude of superiority, but rather provide an opportunity for respectful dialogue, knowing that it is ultimately God who brings conviction to the heart."

Bertil Wiklander, president of the Church's Trans-European region, says, "We must show Muslims that they can trust us, while we stand by our Adventist faith ... We should not underestimate the challenges, but I feel that times are changing and that we can look forward to dialogue and, I pray, successful work among Muslim people."

Regional church leaders have sent the Statement to world church headquarters in Silver Spring, Maryland, where officials will decide how such a statement would "best benefit the mission of the world church," says Pastor Michael L. Ryan, a world church vice president.

While Ryan admits "Statements are not nearly as important as the way church members interact and behave toward people of other faith groups," he does believe they bolster positive relations. "The Gospel Commission instructs the church that every person is invited to know Jesus Christ. This [statement] will provide a relationship tool to help Adventists better understand the people [they] are inviting."

"People, regardless of background and religious affiliation," Ryan adds, "need to be perceived by the church as worthy of genuine respect. Statements such as this one help get that message across."

Source: Adventist News Network, 28 August 2007, “Adventist Statement on Islam," https://www.uccsda.org/News/Statement-on-Islam (accessed March 10, 2010) 


\section{APPENDIX D}

CORE BIBLE STORY LIST 


\section{CORE BIBLE STORY LIST}

Getting started is critical. One important question we must consider is: What are the basic stories we should tell? One of the major purposes of making a list of the Bible truths is to enable us have a criteria for collecting Bible stories. Terry (2008, p. 32) suggests a list of core stories for evangelism: We will adopt these in our efforts in planting churches in Northern Nigeria.

1. Creation of the world

2. Creation of man and woman

3. The first sin and judgment of Adam and Eve

4. Judgment of a sinful world in Noah's day

5. God's promise to Abraham of One to bless all peoples

6. God provides the substitute sacrifice for Isaac

7. The Passover: the blood and the Lamb

8. God gives His holy Law - the Ten Commandments

9. The Sacrifice System—Shedding of sacrificial blood to cover sin

10. The Prophets' messages warning people to repent and the promise of a Redeemer who will suffer for man's sin

11. Birth of Jesus according to prophecy

12. Baptism of Jesus_-"Behold the Lamb of God," testimony of John and the Holy Spirit

13. Jesus and Nicodemus-“You must be born again"

14. Jesus has authority to forgive sin-Paralyzed man and four friends

15. Jesus has authority over nature-Calming the sea 
16. Jesus has authority over demons-Gadarene Demoniac healed of evil spirits

17. Jesus is the resurrection-Jesus raised Lazarus to life

18. Abraham, Lazarus and the rich man-Man must believe the message of the Prophets in this life

19. The last Supper-"This is my broken body and bloodshed for you"

20. Jesus is betrayed, arrested, falsely accused, tried, and sentenced to death

21. The crucifixion, decision for and against Jesus, "It is finished"

22. The Resurrection and appearance to disciples and followers

23. Jesus returns to the Father, the Ascension

24. Jesus the true High Priest, an advocate before the Father

25. Return of Jesus to receive believers unto himself, to judge and punish unbeliever 


\section{REFERENCE LIST}

Allen, D. (2008). Eyes to see, ears to hear. In J. D. Woodbery (Ed.), From seed to fruit: Global trends, fruitful practices, and emerging issues among Muslims. Pasadena, CA: William Carey Library.

Alalade, A. A. (2008). Limiting factors to the success of the Seventh-day Adventist church in Africa: The Nigerian Case study. Ibadan, Nigeria: Agbo Areo Publishers.

Arn, W., \& Arn, C. (1982). The Master's plan for making disciples. Monrovia, CA: Church Growth Press.

Atyap Community Online. The Atyap Nationality. http://atyap.net/AtyapNationality.aspx. Retrieved March 6, 2010.

Atyap Community Online. The Culture and Religion. http://atyap.net/CultureandReligion.aspx. Retrieved March 6, 2010.

Bauer, B. C. (2005). Avoiding comfortable syncretism by critical contextualization. Journal of Adventist Mission Studies, 1(2), 18 - 23.

Burrill, R. (1996). Radical disciples for revolutionary churches. Fallbrook, CA: Hart Research Center.

Burrill, R. (1998). Recovering an Adventist approach to the life and mission of the local church. Fallbrook, CA: Hart Books.

Burrill, R. (1999). Rekindling a lost passion: Recreating a church planting movement. Fallbrook, CA: Hart Research Center.

Burrill, R. (2007). Reaping the harvest: A step-by-step guide to public evangelism. Hartbook, CA.

Colgate, J. (2008). "Bible storying and oral use of the Scriptures." In J. D. Woodberry (Ed.), From seed to fruit: Global trends, fruitful practices, and emerging issues among Muslims. Pasadena, CA: William Carey Library.

Craft, C. H. (2005). Appropriate Christianity. Pasadena, CA: William Carrey Library.

Damsteegt, P. G. (2005). "Have Adventists abandoned the biblical model of leadership for the local church?" In Koranteng-Pipim, S., Here we stand (pp. 643 - 647), Berrien Springs, MI: Adventist Affirm. 
Dayton, E. R. \& Fraser, D. A. (2003). Planning strategies for World evangelism. Eugene, OR: Wipf \& Stock Publishers.

Decret, F. (2009). Early Christianity in north Africa. Eugene, Oregon: Cascade Books.

Dudley, R. L. \& Gruesbeck, C. B. (1989). Plant a church, reap a harvest. Mountain View, CA: Pacific Press Publishing Association.

Falk, P. (1997). The growth of the church in Africa. Bukuru, Nigeria: African Christian Textbooks.

Feeney, J. H. (1988). The team method of church planting. Anchorage, AK: Abbot Loop Christian Center.

Garrison, D. (2006). Church planting movements. Bangalore, India: Sri Sudhindra Offset Process.

Gray, S. (2007). Planting fast-growing churches. St. Charles, IL: Church Smart Resources.

Gray, S. \& Short, T. (2007). Planting fast-growing churches. St. Charles, IL: ChurchSmart Resoources.

Hakim, S. (2009). Religion of Islam. http://www.mnsu.edu/emuseum/cultural/religion/Islam/history.html. Accessed June 4, 2010.

Heibert, P. G. (1985). Anthropological insights for missionaries. Grand Rapids, MI: Baker Book House.

Heibert, P. G. (1987). Critical contextualization: International Bulletin of Missionalia Research, 11(3), 104-112.

Herbert, J. K. (1978). Understanding Christian missions. Grand Rapids, MI: Baker Book House.

Hesselgrave, D. J. (1980). Planting churches cross-culturally. Grand Rapids, MI: Baker Books.

Hesselgrave, D. J(1995, July). "Contextualization that is authentic and relevant." International journal of frontier missions, 12(3), 15-20.

Hesselgrave, D. J. (2004). Syncretism: Mission and missionary induced? Paper presented at the IFMA/ EFMA/ EMS Triennial Conference, St. Louis, MO, September 23 25 .

Hesselgrave, D. J. (2004). "Traditional religion, new religions, and the communication of the Christian faith." Grand Rapids, MI: Kregel. 
Hodges, M. (1957). Build my church. Chicago, IL: Moody Press.

http://en.wikipedia.org/wiki/Islam_in_Nigeria. Accessed May 30, 2010.

Icenogle, G. W. (1994). Biblical foundations for small group ministry: An international approach. Downers Grove, IL: Intervarsity Press.

Jeschke, M. (2010). Islam: The trauma of modernity.

http://seniorspeace.mennonite.net/mjeschke.html. Accessed June 4, 2010.

Jones, T. (2004). Church planting from the ground up. Joplin, MO: College.

Kalu, O. (1978). Christianity in west Africa: The Nigerian story. Ibadan, Nigeria: Day Star Press.

Kane, J. H. (1974). Understanding Christian missions. Grand Rapids, MI: Baker Book House.

Kato, B. H. (1975). "The gospel, cultural context and religious syncretism." Minneapolis: World Wide Publications.

Knight, G. R. (2009). Lest we forget. Daily Devotionals. Hagerstown, MD: Review and Heralds Publishing Association.

Kure, E.M. (2004). "Bringing light to the Muslims." In Wagner, C.P. \& Thompson, J. (Eds.). Out of Africa (Pp.172-186). Ventura, CA: Regal Books

Malphurs, A. (2000). Planting growing churches for the $21^{\text {st }}$ century. Grand Rapids, MI: Baker.

Maigadi, I. B. (2005). The Adventist church in Northern Nigeria. Zaria, Nigeria: Art and Review Publishing.

Martin, C. A. (2005). Questions on C-5. Journal of Adventist mission studies, 1(2), $34=$ 35 .

Martin, C. A. (2006). C-5 Muslims, C-5 missionaries or C-5 strategies? In E. Reynolds et al (Eds.), Journal of the Adventist theological society, 17(2), 122-134. 34-35.

Martin, C. A. (2008). How should the church contextualize for Muslimss? In G. B. Swanson (Ed.), Perspective Digest (pp 18 - 28), ATS, 13(4).

Moreau, A. S. (2005). "Contextualization: From an adapted message to an adapted life." Grand Rapids, MI: Baker Academic.

Mbiti, J. (1980). The encounter of Christian faith and African Religion. Christian Century. 
McClements, W. (1931, August 30). "Progress in the Nigerian mission field," The Adventist Review and Sabbath Herald, 108(34), 9.

McGavran, D.A. (1955). The bridges of God: A study in the strategy of missions. United Kingdom, World Dominion Press.

Moyer, B.C. (2005). Ten universal elements in church planting. Adapted from materials by David Garrison. SBC International Mission Board. Richmond, VA

Mortenson, G. (2009). Stones into schools: promoting peace with books, not bombs, in Afghanistan and Pakistan. New York: Pengon Books.

Nengel, J. G. (2005, August). Towards a history of the Seventh-day Adventist church north of Rivers Niger and Benue (1931 - 2003). Paper presented at the Adventist Educators Association of Nigeria Conference.

Nicholls, B. J. (2006). Contextualization: A theology of gospel and culture. Vancouver, BC Canada: Regent College Publishing.

Nigeria National Bureau of Statistics. Census Figure by State \& LGA, 2006 http://www.nigerianstat.gov.ng/nbsapps/Connections/Pop2006.pdf. Retrieved May 30, 2010.

North-east Nigeria Conference of Seventh-day Adventist. (2009, February). Treasurers report of triennial session at Jengre Hospital Church Jos, Nigeria.

Osei, E. (1997). A strategy for church planting among the Ewe-speaking people of the Volta Region, Ghana (Doctoral Dissertation, Andrews University, 1997).

Palla, A. J. (1994). Church planting manual. Lecture outlines for church planting course (Fuller Theological Seminary 1994).

Parrat, J. (1997). A reader in African Christian theology, SPCK International study guide. London: SPCK.

Pauw, B. A. (1975). Christianity and Xhosa tradition. London: Oxford University Press.

Potts, J. T. (2009). Church planting to reach postmodern generation: Launching a new church in Winnipeg, Manitoba (Doctoral Dissertation, Andrews University, 2009).

Rankin, J. (2006). Empowering kingdom growth to the ends of the earth: Church fulfilling the great commission. Nashville, TN: Broadman \& Holman Publishers.

Rohrmayer, G. (2006). First steps for planting a missional church. St. Charles, IL: ChurchSmart Resources. 
Sahib, M. A. (2009). The Condition of the Arabs before the advent of the Holy Prophet (Pbuh) and the transformation he wrought in them.

http://aaiil.org/text/pbuh/art/others/arabcond.shtml. Accessed June 62010.

Sahlin, M. (2004). Understanding your community: Intuitive assessment tools to launch relevant ministry. Lincoln, NE: Center for Creative Ministry.

Sahlin, M. (2007). Mission in metropolis: The Adventist movement in an urban world. Lincoln, NE: Center for Creative Ministry.

Schaller, L. E. (1979). Understanding church growth and decline. New York: Pilgrim.

Schantz, B. (1993). Your Muslim neighbour and you: A manual for personal evangelism. Seventh-day Adventist Global Centre for Islamic Studies, Binfield, Bracknell, Berkshire, England.

Schantz, B. (2003). Islam in the 9/11 world. Alma Park, Grantham, Lincs.: Autumn House.

Schwarz, C. A. (1996). Natural church development: A guide to eight essential qualities of healthy churches. St Charles, IL: ChurchSmart Resources.

Seventh-day Adventist Year Book. (1980). Washington, DC: Review and Herald Publishing Association.

Shelley, F. M. \& Audrey, E. C. (2009). Basis of becoming a Muslim. http://www.islamicity.com/mosque/muslim.htm. Accessed June 14, 2010.

Strong, C. A \& Page, M. (2006). A worldview approach to ministry among Muslim women. Passadena, CA: William Carrey Library.

Sutter, K. (2006). Keys to church planting movements. MI: Asteroidea Books.

Taber, S. (2004). Muslims next door: Uncovering myths and creating friendships. Grand Rapids, MI: Zondervan.

Terry, J. O. (2008). Basic Bible storying: Preparing and presenting Bible stories for evangelism, discipleship, training, and ministry. Fort Worth, TX: Church Starting Network.

Tippett, A. (1970). People movements in Southern Polynesia. Chicago: Moody Press.

Van Rheenen, G. (2006). Contextualization and Syncretism: Navigating cultural currents. Passadena, CA.

Wagner, P. C. (1990). Church planting for a greater harvest. Ventura, CA: Regal Books.

Walter, A. E. (1996). Ekklesia. In the Theological Dictionary of the Bible. Grand Rapids, MI: Baker Books. 
Werning, W. J. (2003). The seed-planting church: Nurturing churches to health. St Charles, IL: ChurchSmart Resources.

White, E. G. (1891, December 21). The Adventist review and Sabbath herald, 68(50).

White, E. G. (1898, April 28). "The Christian commission." The Adventist review and Sabbath herald.

White, E. G. (1903). Evangelism. Mountain View, CA: Pacific Press.

White, E. G. (1911). The Acts of the Apostles. Mountain View, CA: Pacific Press.

White, E. G. (1940). The Desire of Ages. Mountain View, CA: Pacific Press.

White, E. G. (1942). The Ministry of Healing. Mountain View, CA: Pacific Press Publishing Association.

White, E. G. (1946). Evangelism. Washington DC: Review \& Herald Publishing Association.

White, E. G. (1948). Testimonies for the Church (8). Mountain View, CA: Pacific Press.

White, E. G. (1956). Steps to Christ. Mountain View, CA: Pacific Press Publishing Association.

White, E. G. (1958). Selected messages vol. II. Washington DC: Review \& Herald Publishing Association.

White, E. G. (1962). Testimonies to ministers. Mountain View, CA: Pacific Press Publishing Association.

White, E. G. (1962). Testimonies to ministers and gospel workers. Mountain View, CA: Pacific Press Publishing Association.

White, E. G. (1963). Medical Mininistry. Mountain View, CA: Pacific Press.

White, E. G. (1983). Christian Service. Washington DC: Review \& Herald Publishing Association.

White, E. G. (1995). Pastoral Ministry. Mountain View, CA: Pacific Press Publishing Association.

Woodberry, J. D. (2011). "Bible storying and oral use of the Scriptures." From seed to fruit: Global trends, fruitful practices, and emerging issues among Muslims. Pasadena, CA: William Carey Library

Young, J. T. (1979). The Holy Spirit and the birth of churches. Nashville, TN: Broadman Press. 
Young, T. (2003). Reading in African politics. Bloomington $\mathrm{IN}$ : Indiana University Press.

Zangon Kataf. http://en.wikipedia.org/wiki/Zangon_Kataf. Retrieved October 20, 2009.

Zunkle, C.A. (1989). Church growth under fire. Scott dale, Pa.: Herald Press. 
VITA

\section{Personal Data}

Name: Francis Freeman Daria

Date \& Place of Birth: September 15, 1953

Marital Status: Married (children: 3 boys $\& 3$ girls)

Spouse: Tani Daria

\section{Education:}

2009- 2011: DMin. Andrews University Theological Seminary

2002-2005: M.A.Religion, Andrews University (Babcock Campus)

1998-2002: B.A. Theology, Andrews University (Babcock Campus)

1974-1979: Government Secondary School Kagoro, Kaduna State, Nigeria

1968-1974: Local Education Primary School Bato, Kaduna State, Nigeria

\section{Working Experience:}

2006-2009: Conference Evangelist (NENC)

2003-2006: Conference Secretary (NENC)

1998-2002: Student Pastor (Babcock University)

1996-1998: Sabbath School/Personal/Children Ministries Director (NEM)

1994-1995: District Pastor (NEM)

1990-1993: Intern Pastor (NEM)

1980-1990: Civil Servant, Ahmadu Bello University Zaria, Nigeria

Ordination to the Gospel Ministry: February 11, 1995 